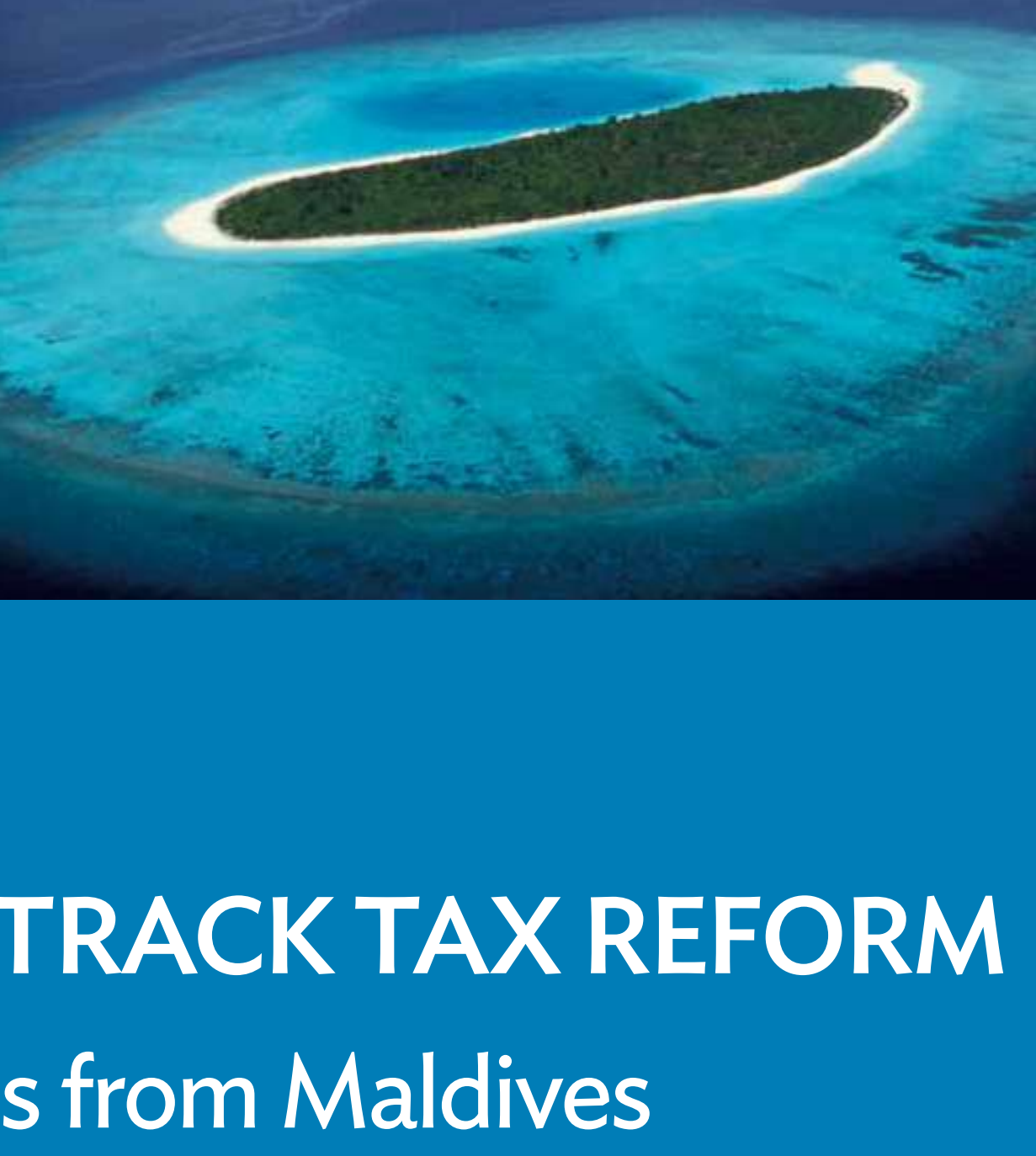

FAST-TRACK TAX REFORM Lessons from Maldives 


\section{FAST-TRACK TAX REFORM Lessons from Maldives}


(c) (1)

(C) 2017 Asian Development Bank

6 ADB Avenue, Mandaluyong City, 1550 Metro Manila, Philippines

Tel +632632 4444; Fax +6326362444

www.adb.org

Some rights reserved. Published in 2017.

ISBN 978-92-9257-957-9 (Print), 978-92-9257-958-6 (e-ISBN)

Publication Stock No. TIM178673-2

DOI: http://dx.doi.org/10.22617/TIM178673-2

The views expressed in this publication are those of the authors and do not necessarily reflect the views and policies of the Asian Development Bank (ADB) or its Board of Governors or the governments they represent.

ADB does not guarantee the accuracy of the data included in this publication and accepts no responsibility for any consequence of their use. The mention of specific companies or products of manufacturers does not imply that they are endorsed or recommended by $A D B$ in preference to others of a similar nature that are not mentioned.

By making any designation of or reference to a particular territory or geographic area, or by using the term "country" in this document, $A D B$ does not intend to make any judgments as to the legal or other status of any territory or area.

This work is available under the Creative Commons Attribution 3.0 IGO license (CC BY 3.0 IGO)

https://creativecommons.org/licenses/by/3.o/igo/. By using the content of this publication, you agree to be bound by the terms of this license. For attribution, translations, adaptations, and permissions, please read the provisions and terms of use at https://www.adb.org/terms-use\#openaccess

This CC license does not apply to non-ADB copyright materials in this publication. If the material is attributed to another source, please contact the copyright owner or publisher of that source for permission to reproduce it. ADB cannot be held liable for any claims that arise as a result of your use of the material.

Please contact pubsmarketing@adb.org if you have questions or comments with respect to content, or if you wish to obtain copyright permission for your intended use that does not fall within these terms, or for permission to use the ADB logo.

Notes:

In this publication, "\$” refers to US dollars.

Corrigenda to ADB publications may be found at http://www.adb.org/publications/corrigenda

Unless specified, all photos are from Maldives Inland Revenue Authority. 


\section{Contents}

Tables, Figures, and Boxes $\quad$ vi

Abbreviations

Currency Equivalents $\quad$ ix

Preface $\quad$ xi

Message from the Vice-President, Maldives xifi

Foreword from the Vice-President, Asian Development Bank xv

Executive Summary $\quad$ xvi

Tax Reform Milestones $\quad$ xvifi

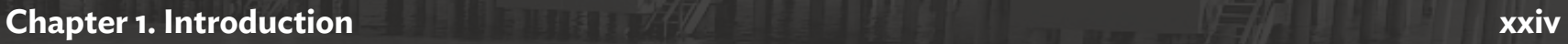

Background 2

Tourism Dependency 2

Tax Reform 3

Chapter 2. Government Revenues before 2011 and the Tax Reform Program 6

Composition Revenues $\quad 8$

Import Duties 8

Resort Lease Rents $\quad 8$

Business Profits and Property and Investment Income 10

$\begin{array}{lr}\text { Tourism Tax } & 10\end{array}$

Bank Profit Tax 12

Imperatives for Reform $\quad 13$

External Technical Assistance $\quad 15$

Lessons 16

Chapter 3. Introduction of New Taxes 18

$\begin{array}{lr}\text { Political Evolution of Tax Reform } & 20\end{array}$

Introduction of New Taxes $\quad 21$

Business Profit Tax 23

Business Profit Tax Regulations $\quad 24$

Proposed Corporate Profit Tax and Personal Income Tax 25

Direct Consequences of Indecision and Confusion 26

Tourism Goods and Services Tax 26

Lessons 27

$\begin{array}{lr}\text { Goods and Services Tax } & 28\end{array}$

Standardization of Lease Rents Charged to Resorts 34

Lessons $\quad 35$

$\begin{array}{lr}\text { Special Economic Zones } & 36\end{array}$ 
Chapter 4. Establishment of the Tax Administration System 38

Inception of Maldives Inland Revenue Authority 40

Relationship between Maldives Inland Revenue Authority and the Government 43

$\begin{array}{lr}\text { Organizational Structure } & 46\end{array}$

$\begin{array}{lr}\text { Internal Committees } & 48\end{array}$

$\begin{array}{lr}\text { Staff Complement } & 49\end{array}$

$\begin{array}{lr}\text { Internal Administrative Procedures } & 50\end{array}$

$\begin{array}{ll}\text { Staff Training } & 51\end{array}$

On-the-Job Training by External Consultants

Lessons $\quad 53$

Revenue Collection Priorities $\quad 54$

$\begin{array}{ll}\text { Registration of Taxpayers } & 56\end{array}$

$\begin{array}{lr}\text { Taxpayer Services } & 57\end{array}$

$\begin{array}{lr}\text { Public Awareness Campaigns } & 60\end{array}$

$\begin{array}{ll}\text { Recordkeeping Education } & 63\end{array}$

$\begin{array}{lr}\text { Taxpayers' Charter } & 64\end{array}$

$\begin{array}{ll}\text { Tax Rulings } & 66\end{array}$

Publication of Guidelines $\quad 66$

$\begin{array}{lr}\text { Compliance } & 68\end{array}$

$\begin{array}{ll}\text { Audit } & 69\end{array}$

$\begin{array}{ll}\text { Registered Auditors } & 72\end{array}$

$\begin{array}{ll}\text { Large Taxpayer Services } & 73\end{array}$

$\begin{array}{ll}\text { Objections and Appeals } & 73\end{array}$

$\begin{array}{ll}\text { Tax Appeal Tribunal } & 74\end{array}$

$\begin{array}{ll}\text { Enforcement } & 74\end{array}$

$\begin{array}{ll}\text { Licensed Tax Agents } & 75\end{array}$

$\begin{array}{ll}\text { Revenue Estimates and Reports } & 76\end{array}$

$\begin{array}{ll}\text { Liaison with Other Government Bodies } & 76\end{array}$

$\begin{array}{ll}\text { International Tax Matters } & 76\end{array}$

$\begin{array}{ll}\text { Information Technology Requirements } & 77\end{array}$

$\begin{array}{ll}\text { Lessons } & 80\end{array}$

Chapter 5. Some Unique Difficulties and Challenges of Implementation 82

Four Particular Implementation Challenges $\quad 84$

$\begin{array}{lr}\text { Dichotomized Economy } & 84\end{array}$

Changing Government Priorities and the Time Constraint 86

$\begin{array}{ll}\text { Policy and Legislative Shortcomings } & 87\end{array}$

Taxpayer Voluntary Compliance and Self-Assessment 89

$\begin{array}{ll}\text { Lessons } & 90\end{array}$

$\begin{array}{lr}\text { Use of External Expertise } & 90\end{array}$

$\begin{array}{ll}\text { Lessons } & 92\end{array}$ 
Chapter 6. Success Factors

Key Success Factors

Revenue Collection

Contribution to State Coffers

Tax-Gross Domestic Product Ratio

Composition of Total Government Revenue

100

Composition of Revenue Collected by Maldives Inland Revenue Authority

102

Tax Receipts

104

Staff

107

Registration of Taxpayers

109

Compliance

110

Audit

111

Enforcement

114

Objections

114

Litigation

115

Tax Rulings

115

Taxpayer Education

116

Tax Administration Expenditure

Chapter 7. Maintaining the Impetus

Budget Deficits

New Taxes

124

Impact of the Tourism Sector

126

Future Strategy of Maldives Inland Revenue Authority

Chapter 8. Learning from the Maldives Experience

Tax Legislation

Tax Administration

What Tax Policymakers Have to Say

What Tax Administrators Have to Say 


\section{Tables, Figures, and Boxes}

\section{TABLES}

$1 \quad$ Goods and Services Tax Rates

2 Tourist Resort Lease Rent Scale $\quad 34$

3 Maldives Inland Revenue Authority's Service Standards $\quad 65$

4 Guides Published by Maldives Inland Revenue Authority (2011-2015) 66

5 Technical Assistance Projects (2011-2015) 92

6 Total Tax Revenue Collection (2010-2015) 97

7 Revenue Collected by Maldives Inland Revenue Authority, 2010-2015 102

8 Maldives Inland Revenue Authority Staff Profile (2011-2015) 108

9 Maldives Inland Revenue Authority's Strategic Priorities and Key Performance Indicators (2015-2019) 128

\section{FIGURES}

1 Annual Tourist Arrivals (1997-2015) 3

2 Composition of Government Revenue (2002) $\quad 9$

3 Composition of Government Revenue (2010) 9

4 Tourism Tax $(1980-2015) \quad 12$

5 Bank Profit Tax (1986-2015) 13

6 Maldives Political Tax Reform Timetable $\quad 20$

7 Legislative Activities during the Tax Reform Period $\quad 22$

8 Information Flows Between Government and Tax Administration 43

9 Organizational Structure of Maldives Inland Revenue Authority 46

10 Total Revenue Collection (2010-2015) $\quad 98$

11 Percentage of State Revenue Collected by MIRA (2010-2015) 98

12 Tax-Gross Domestic Product Ratios (2010-2016) 99

13 Tax Revenue Composition (2000) 100

14 Tax Revenue Composition (2011) 101

15 Tax Revenue Composition (2014) 101

16 Composition of Tax Revenue Collected by Maldives Inland Revenue Authority (2010-2015) 103

17 Percentage Composition of Revenue Collected by Maldives Inland Revenue Authority in $2015 \quad 104$

18 Revenue Receipts (in US Dollars, 2010-2015) 105

19 Currency Composition of Tax Receipts (2010-2015) 105

20 Staff Complement (2010-2015) 107

21 Taxpayer Registrations (2011-2015) 109

22 Total Compliance Visits (2011-2015) 110

23 Audits (2011-2015) 112

24 Additional Taxes Assessed from Audits (2011-2015) 112

25 Total Amount of Recoveries from Enforced Action (2011-2015) 114

26 Objections Received and Objections as Percentage of Audits (2011-2015) 114 
27 Litigation (2011-2015) 115

28 Tax Rulings Issued (2011-2015) 116

29 Taxpayer Presentations and Workshops (2011-2015) 116

30 Participation in Taxpayer Presentations and Workshops (2011-2015) 117

31 Composition of Administration Expenditure (2011-2015) 119

32 Administration Expenditure per Rf1 Collected (2011-2015) 120

33 Annual Growth in Tourist Arrivals (1998-2015) 126

34 Average Length of Stay per Tourist (1997-2015) 127

\section{BOXES}

$1 \quad$ Broader Reforms Under the Economic Recovery Programme 14

2 Confused Commencement 23

3 Writing Tax Depreciation Rules $\quad 24$

4 The Coinage Problem $\quad 29$

5 Maldives Inland Revenue Authority's Vision Statement $\quad 41$

6 Maldives Inland Revenue Authority's Mission Statement $\quad 48$

7 Maldives Inland Revenue Authority's Logo 50

8 Survey of Male' Rental Properties $\quad 57$

9 Maldives Inland Revenue Authority's Core Values 80 


\section{Abbreviations}

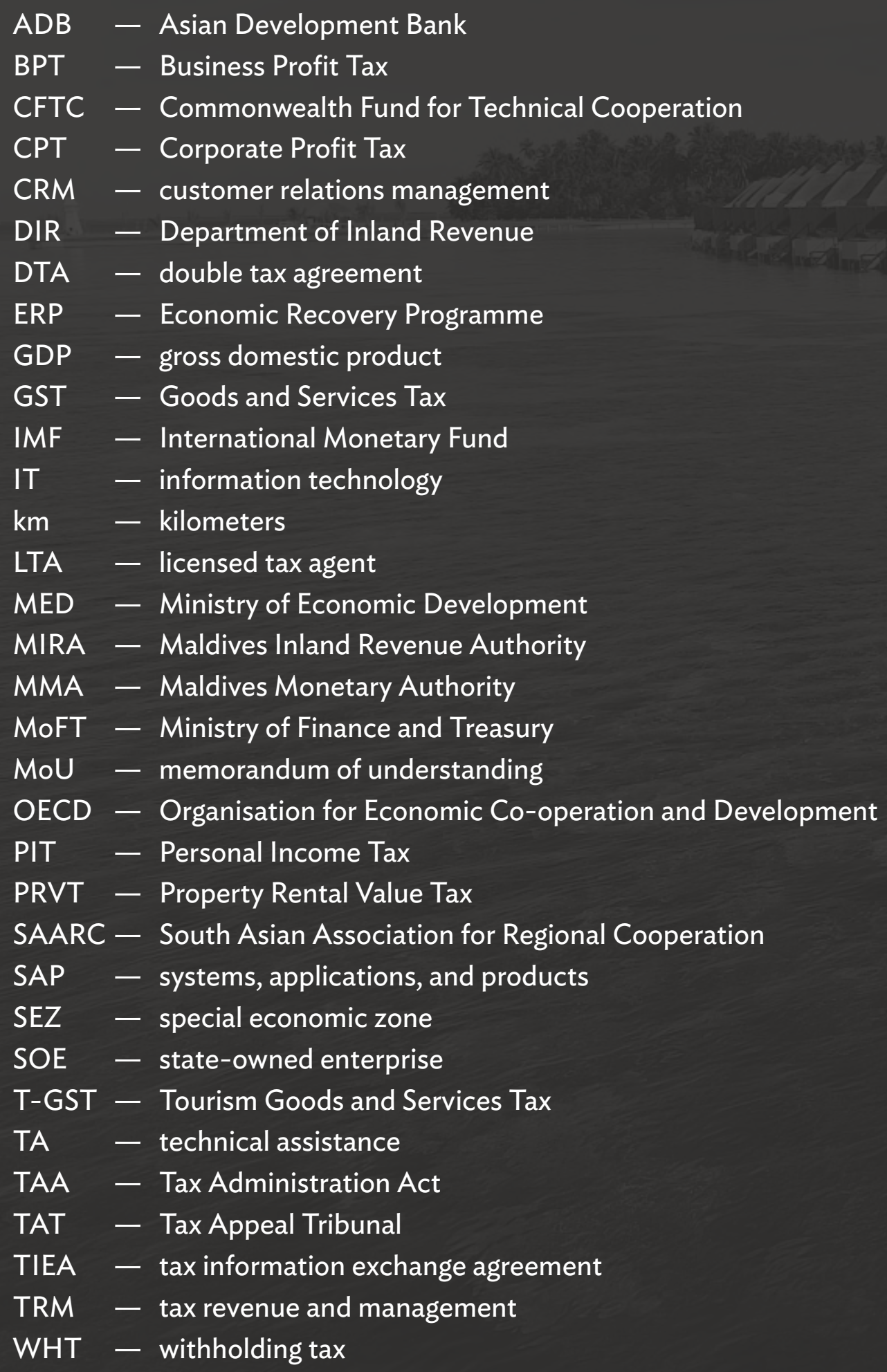




\section{Currency Equivalents}

(as of 31 December 2015)

Currency unit - rufiyaa (Rf)

Rf1.00 $=\$ 0.064893$

$\$ 1.00=R f 15.41000$

Unless otherwise stated, “\$” refers to US dollars. 


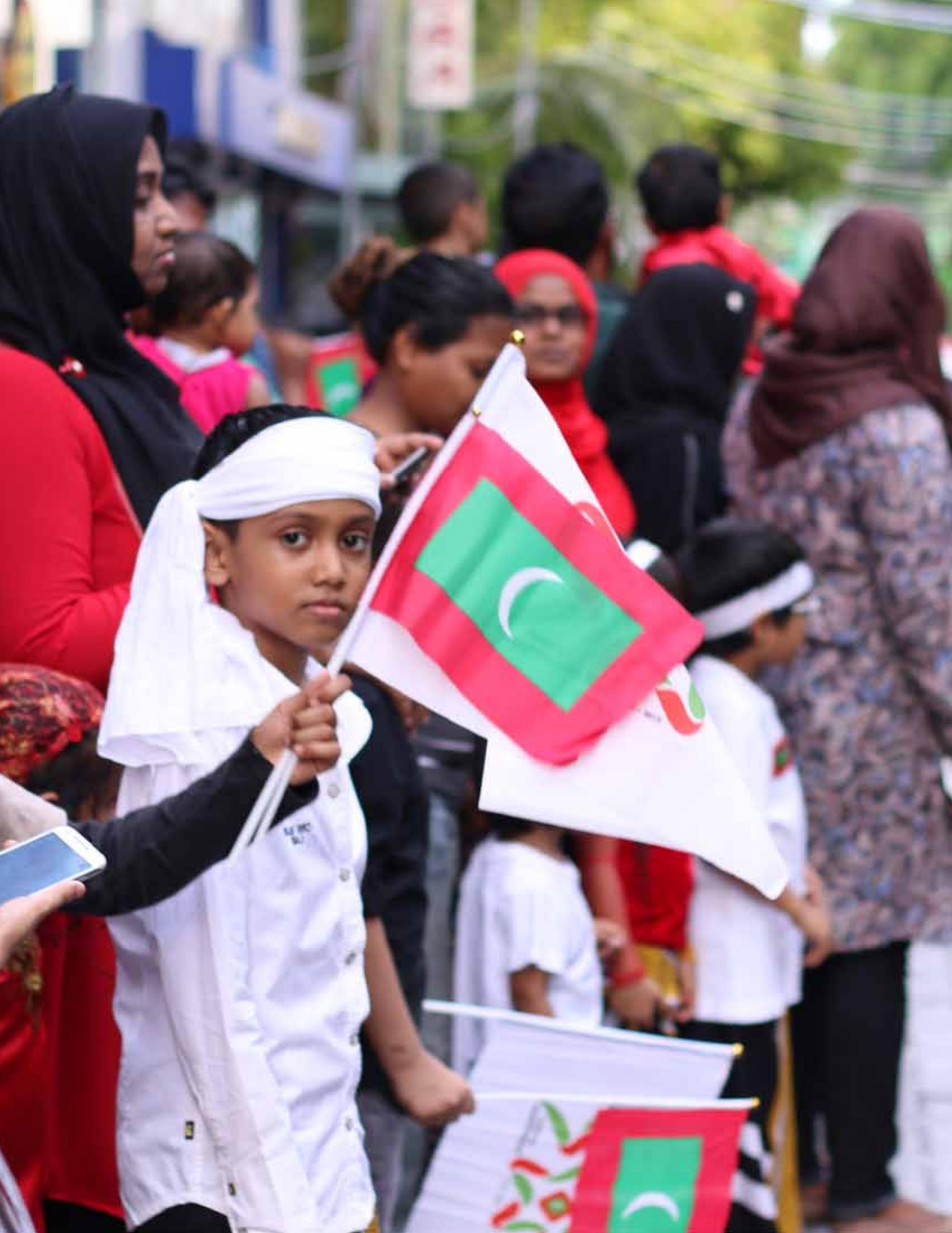


By Western taxation norms, Maldives was in essence a tax haven until 2011. It had no general income taxes. Government revenue was sourced totally from import duties, taxes on tourists and banks, land and resort island rents, business and other property income, fees and levies, and foreign aid.

That government revenue base had to change as the country came under intense economic pressure in the first decade of the 21st century, primarily as a result of the aftereffects of the 26 December 2004 tsunami and the 2008-2009 global financial crisis. This fiscal predicament, together with a growing domestic and international appetite for change in the way Maldives government revenue was raised, culminated in the introduction in 2011 of a goods and services tax (GST), first restricted to the tourism sector but quickly rolled out into a general GST across the whole economy. In addition, 2011 also saw the introduction of a broad based business profit tax (BPT).

This book details how the Government of Maldives was able to successfully introduce direct and indirect taxes in a remarkably short period, and particularly how Maldives Inland Revenue Authority (MIRA) was able to implement a largely successful tax administration system to enable the collection of those taxes and other government-imposed levies.

In addition, this publication:

- highlights the factors to Maldives' success, which other developing countries might emulate, and

- notes the lessons to be learned from Maldives, experience, so that other developing countries can avoid the same pitfalls.
This report could not have been possible without the valuable time and comments given by key actors in the development of Maldives tax reforms, and people interacting with the new regimes. These include former Maldives Presidents Maumoon Abdul Gayoom and Mohamed Nasheed, Vice-President and former Minister of Finance and Treasury Abdulla Jihad, former Vice-President Ahmed Adeeb Abdul Ghafoor, former Ministers of Finance Ali Hashim and Ahmed Inaz, former Permanent Secretary of the Ministry of Finance and Treasury Ismail Alimanik, Commissioner General of Taxation Yazeed Mohamed and his Deputy Hassan Zareer, and former MIRA Director GeneralAudit and Investigation Fathuhulla Jameel. Also significant to this publication were the efforts of private sector participants Arshad Jameel, Anwarusalam Aboobakuru, Krishna Rengaraj, Abdullah Thayyib, Abdulla Zuhuree, business student Fathmath Shaha Hassan, ADB international tax advisors Kevin Holmes and Colin Hutchins, and other contributors who wished to remain anonymous. In addition, thanks to Aiman Ibrahim, Asma Shafeeu, Aminath Ali Maniku, Ahmed Saruvash Adam, Maryam Abbas, Aishath Leeza Ahmed, Mariyam Himmath Hassan, Abdul Ghaffar Abdulla, Mohamed Haamy, Ali Mahir, Faatheen Abdul Latheef, and Mohamed Nisam Naseem for their background research and administrative support in compiling the book.

This publication is based on data available as of 31 December 2015. 



\title{
Message from the Vice-President
}

Tax reform in Maldives began in the mid-1990s when the Commonwealth Secretariat first provided technical support to address the country's public finance management situation. That assistance was followed by an International Monetary Fund investigation into appropriate tax policy options for Maldives. After a long period of research and consultation, business profit tax and two goods and services taxes were introduced in 2011. As the title of this book indicates, the implementation of these taxes was "fast-tracked."

By 2011, Maldives was under fiscal pressure and the rapid implementation of the new revenue gathering measures was intended to alleviate that pressure quickly. As this book shows, the swift adoption of the tax reforms has brought much needed additional revenue to the government. But it had not always been a smooth path for taxpayers and tax administrators alike, and there are lessons to be learned from our experience.

I wish to record my appreciation for the support given by the Asian Development Bank and other international technical assistance agencies, which they provided during the whole period of our tax restructuring initiatives. Their assistance has been vital in shaping the tax system which operates in Maldives today. This publication is valuable to document our experience so that we and others may learn from it.

Now we must focus on the future. By building on the successes of the past, we need to strive to broaden the tax base and to improve the efficiency of our tax collection mechanisms.

\author{
Abdulla Jihad \\ Vice-President of Maldives
}



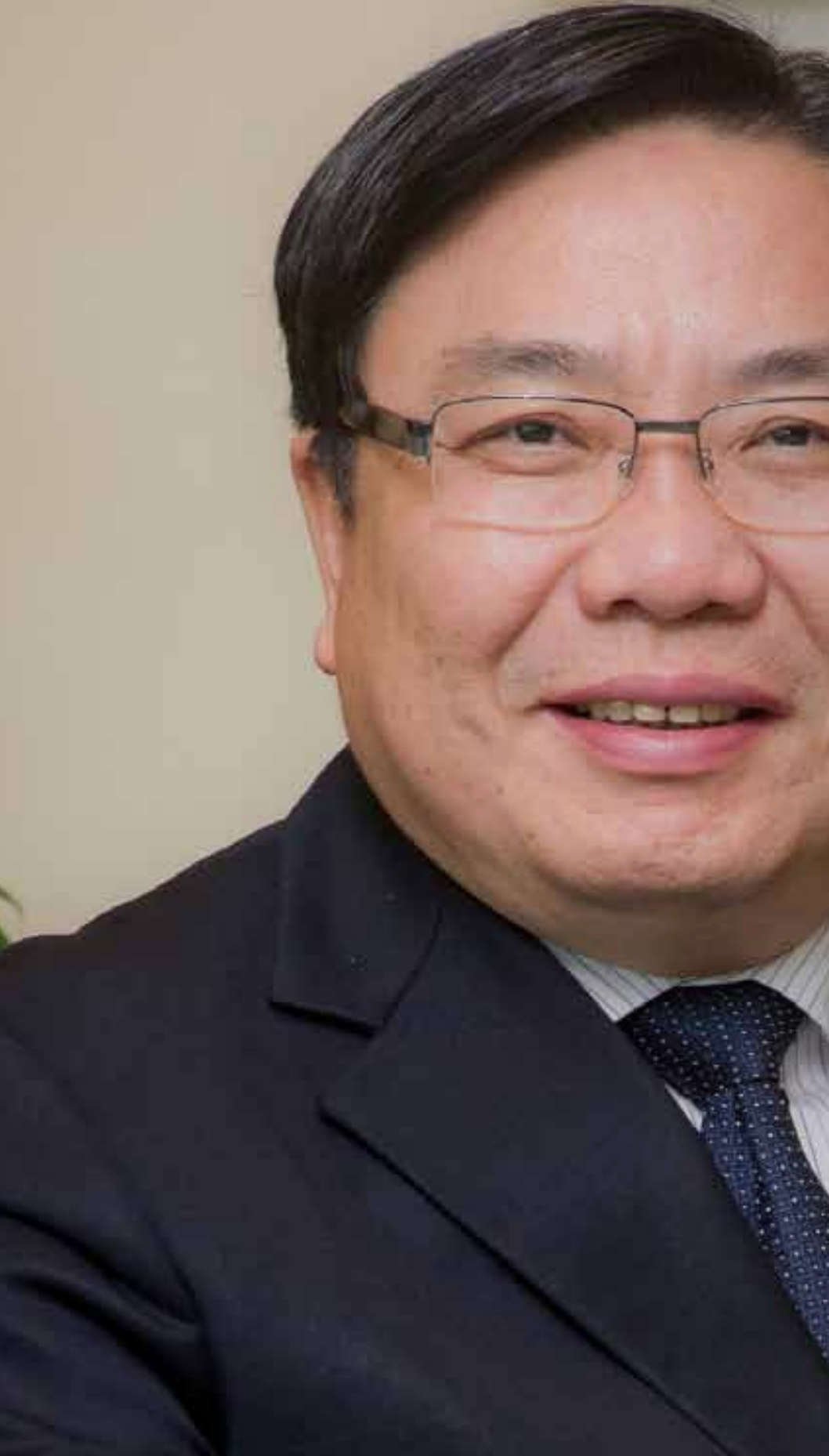


\section{Foreword from the Vice-President Asian Development Bank}

Maldives has achieved high economic growth, averaging $7.2 \%$ per year from 1980 to 2015 , and obtaining middle-income status in 2011. Nominal gross domestic product (GDP) per capita reached $\$ 9,000$ in 2015, considered the highest in South Asia. Critically, the transformation of its revenue system over the past 6 to 7 years has been an important driver enabling financing of government services to improve the benefits of such growth to the people of Maldives. With the help of development partners, Maldives is one of the few countries that has transformed its revenue system into a modern, e-enabled system so quickly and so successfully.

Before 2004, government revenue (including grants) and reflecting trade duties had been around $20 \%$ of GDP. It reached $30 \%$ of GDP after the 2004 tsunami and partly as a result of a large volume of foreign aid. It then declined again to $20 \%$ of GDP in 2009 due to the resulting instability from the global financial crisis. As government revenues were mainly sourced from taxes and levies imposed on the tourism sector which was adversely impacted by the exogenous shocks, there was considerable pressure to seek alternative sources of funding. The government therefore had to undertake an ambitious reform agenda with the aim of diversifying revenue sources and broadening its tax base.

Starting with the Economic Recovery Program in 2009, the Asian Development Bank (ADB) helped lay the groundwork to improve fiscal management by helping facilitate critical legislation and its efficient implementation resulting in a more diversified tax base and higher tax collection. Subsequent technical assistance supported further taxation policy reforms, established the Maldives Internal Revenue Authority (MIRA), and facilitated MIRA's automation drive. After introducing the new tax system, government revenue has been increasing by more than $10 \%$ per year since 2013. The tax revenue has reached around $20 \%$ of GDP in 2014 and total government revenue exceeded $30 \%$ of GDP, considered one of the top levels among South Asian countries. This book describes the efforts and achievements of the Government of Maldives in introducing the new taxes, and of MIRA in implementing a tax administration system to enable the collection of those taxes and other government-imposed levies.

The Government of Maldives' fiscal balance has been improving due to the successful increase in revenues. However, two characteristics of the Maldivian economy, namely, the archipelagic nature of the country with a dispersed population and its implications on the cost of service delivery, and the prominent role of tourism on tax revenue and the growth of the economy, require MIRA to be continually managed efficiently and effectively.

Publication of this book was prepared by the team comprising Ma. Kristina Hidalgo and Kristina Recomono of the South Asia Public Management, Finance and Trade Division (SAPF) and financed by the technical assistance Strengthening Knowledge Driven Development in South Asia, and includes intellectual inputs from MIRA. The book highlights the combined work from the ADB supported Economic Recovery Program led by Kyung-Nam Shin and Hiranya Mukhopadhyay both formerly from SAPF and technical assistance projects under Natalie Bertsch and Kristina Hidalgo These teams were closely guided by Bruno Carrasco, Director (SAPF) under the leadership of Hun Kim, Director General of the South Asia Department. The teams have worked closely alongside MIRA throughout its challenging journey and developed a very strong partnership. ADB is committed to continuing its strong support to the Government of Maldives and MIRA in its endeavors to maintain an e-enabled, state-of-the-art revenue system with resulting benefits to the economy and the people of Maldives.

Wencai Zhang

Vice-President (Operations 1) Asian Development Bank 
The Maldives economy is reliant on the tourism sector. Historically, government revenue has been sourced, together with imports and foreign aid, from taxes and levies imposed on that sector, which has exposed the government's fiscal position to exogenous shocks. To mitigate against the risks associated with the high level of dependence on the tourism industry, the Maldives tax base needed to be widened.

The December 2004 tsunami, which caused severe damage to the country, and the 2008-2009 global financial crisis (GFC), followed by a period of rapidly increasing government expenditure, intensified the need for the government to implement tax reform measures. The reforms were facilitated by a change of government in 2008 . However, the post-2008 political mix required the new government to make compromises, and contributed to the delay in implementing the new tax regime until 2011.

In 2010, Maldives Inland Revenue Authority (MIRA) was established to administer all taxes imposed by the state and to implement three new taxes, which were introduced within a period of 9 months in 2011: tourism goods and services tax (T-GST), general goods and services tax (GST), and business profit tax (BPT). The T-GST first took effect on 1 January 2011, followed by the BPT on 18 July 2011. On 2 October 2011, the GST replaced the T-GST and imposed different rates for the tourism sector. The GST was introduced under a challenging timeframewith only one month from the presidential ratification of the GST Act until its implementation-which meant that neither taxpayers nor the tax administration was properly prepared for it.

The commencement of those taxes within such a short period of each other, together with Corporate Profit Tax (CPT) and Personal Income Tax (PIT) bills introduced into Parliament at the same time, placed extraordinary pressure on MIRA's resources, which necessitated extensive and urgent external support to help MIRA develop regulations and rulings, internal administration and collection procedures and IT systems, and deliver staff training and public awareness programmes.

Nevertheless, against that background, there is no doubt that the tax reforms carried out in Maldives since 2011 have been very successful. The primary objective was to increase the government's tax revenue and to widen its tax base, and that has been well achieved. Furthermore, although the reforms were implemented under extreme time and resource pressures-and sometimes in the midst of political and legislative challenges-MIRA's service performance continually improved throughout the period 2010-2015.

Numerous lessons at the tax policy, legislation and administration levels can be drawn from the Maldives experience. At the policy level, the main message is to ensure that $\operatorname{tax}$ revenue reform requirements are addressed in a timely and expeditious manner; in particular, that their implementation is not deferred for political convenience. In addition, the government must clearly articulate its policy position, and the reforms need to be introduced in accordance with a realistic timetable, which achieves a pragmatic tradeoff between meeting the government's fiscal requirements, and being acceptable to the public and capable of practical implementation.

Tax legislation must be written clearly and unambiguously (with accurate English translations), be consistent with the country's Constitution and other laws, and be regularly reviewed and updated. It is vital that the legal draftsmen liaise with tax policymakers and administrators to ensure that the language of the legislation accurately conveys its policy purpose and can actually be applied in the field.

The key to the successful development of a nascent tax administration is the establishment of a revenue authority that is independent of the government (but has strong communication links with it); is led by a senior management team that has a clear strategic vision and establishes and achieves attainable 
operational targets; implements a properly planned and organized administrative system; is staffed by appropriately qualified personnel who are enthusiastic about achieving the tax authority's goals and who have the benefit of the long-term presence on the job of experienced external support.

For the tax authority to succeed, the government must allocate adequate resources to enable it to properly carry out its mandate, especially with respect to staff training and public awareness programmes, and the establishment of a modern and comprehensive IT system.

As Maldives benefited from the experience of tax reforms in other countries, introduced with support from $\mathrm{ADB}$ and other development partners, the lessons from Maldives' fast-track approach to tax reform will also benefit other developing countries with fledgling tax systems, even as Maldives continues to build on the robust foundations of its new tax system. 


\section{Tax Reform Milestones}

\section{0}

\section{March}

- President ratifies the Tax Administration Act

\section{August}

- President appoints the Commissioner General, Deputy Commissioner General, and Board members of Maldives Inland Revenue Authority (MIRA)

\section{September}

- President ratifies the Tourism Goods and Services Tax (T-GST) Act

- President ratifies the second amendment to the Tourism Act, authorizing a change to the basis for calculating resort land lease rents

\section{October}

- MIRA commences operations

- MIRA begins its taxpayer registration campaign

20 December

- T-GST Regulation gazetted

\section{December}

- Tourism Land Rent Regulation gazetted

\section{1}

\section{January}

- $3.5 \% \mathrm{~T}-\mathrm{GST}$ commences

- MIRA opens its Male' Taxpayer Service Centre

\section{January}

- President ratifies the Business Profit Tax (BPT) Act

\section{February}

- MIRA issues its first Tax Ruling

\section{February}

- MIRA issues its first monthly revenue report

\section{April}

- MIRA issues its first quarterly report 


\section{June}

- MIRA issues its policy on action against persons with dues to the state

\section{July}

- BPT commences

\section{August}

- BPT Regulation gazetted

\section{September}

- President ratifies the General Goods and Services Tax (GST) Act

\section{September}

- Public awareness campaign begins

\section{September}

- MIRA issues policy on providing relief for islands and land developed as tourist resorts and hotels

\section{0 ctober}

- T-GST ends

- GST Regulation gazetted

\section{October}

- $3.5 \%$ GST begins

\section{October}

- MIRA establishes a 1415 hotline for taxpayers

\section{December}

- President ratifies first amendment to the Tax Administration Act, which includes provisions relating to MIRA's reporting requirements, auditing powers, and procedures; tax agents; taxpayer obligations; tax assessments, objections and appeals; and offenses and penalties

\section{December}

- Revenue collections reach Rf4.56 billion

\section{2}

\section{January}

- GST rate increases to $6 \%$

\section{March}

- MIRA issues policy on disclosure of noncompliant GST-registered persons

\section{April}

- Auditor registration begins 


\section{April}

- MIRA issues policy on skip tracing persons with outstanding payments

\section{April}

- Tax Appeal Tribunal Regulation gazetted

31 May

- MIRA issues its first Annual Report

\section{June}

- MIRA issues policy on dishonored checks

\section{August}

- MIRA issues policy on accessing information on bank accounts and freezing bank accounts

\section{September}

- MIRA begins producing its own TV program, Vaaru [Tax]

\section{November}

- Kulhudhuffushi Branch commences operations

\section{December}

- First tax case filed with the Tax Appeal Tribunal

\section{December}

- MIRA launches its SAP Tax and Revenue Management system

\section{December}

- First search warrant executed

\section{December}

- Revenue collections reach Rf7.15 billion

\section{3}

\section{January}

- GST rates increases from $6 \%$ to $8 \%$ (tourism sector) and $6 \%$ (nontourism sector)

\section{May}

- MIRA launches its MIRAconnect online taxpayer portal

\section{May}

- Tax Administration Regulation gazetted

\section{June}

- First annual "tax week" begins

\section{December}

- Revenue collections reach Rf8.98 billion 


\section{4}

1 January

- MIRA establishes its Large Taxpayer Service Department

6 February

- President ratifies the first amendment to the GST Act, authorizing an increase in the tourism sector GST rate from $8 \%$ to $12 \%$ from 1 November 2014, the imposition of GST on telecommunications, and the exemption of postal services from GST

\section{April}

- Huravee Collection Centre, the second collection center in Male', opens

\section{May}

- GST on telecommunications begins

\section{May}

- President ratifies the 11th amendment to the Airport Service Charge Act, authorizing an increase in the airport service charge from $\$ 18.50$ to $\$ 25$ per tourist from 1 July 2014

\section{June}

- Tax Agents Regulation gazetted

\section{June}

- Enforced revenue collections since MIRA's inception reaches Rf1 billion

\section{August}

- MIRA launches its Strategic Plan 2015-2019

- Taxpayers' Charter published

- First Ran Laari (Gold Coin) awards presented to taxpayers with outstanding compliance

\section{0 ctober}

- \$25 airport service charge begins ${ }^{1}$

\section{November}

- GST rate (tourism sector) increases from $8 \%$ to $12 \%$

\section{November}

- President ratifies the second amendment to the GST Act, exempting government-supplied social housing from GST

\section{November}

- Tourism tax ends

\footnotetext{
1 Notwithstanding that the 5 May 2014 11th Amendment to the ASC Act provided for the increase in the ASC to take effect from 1 July 2014.
} 


\section{December}

- First tax agent licence issued

- President ratifies the third amendment to the GST Act, authorizing a reduction in the GST rate on domestic air transportation for Maldivians from $12 \%$ to $6 \%$

\section{December}

- President ratifies the sixth amendment to the Tourism Act, authorizing the imposition of a Green Tax from 1 November 2015

\section{December}

- Revenue collections reach Rf11.5 billion

\section{5}

\section{February}

- MIRA issues its Enforcement Policy

\section{February}

- Fuvahmulah Collection Centre opens

\section{April}

- New Male' Taxpayer Service Centre opens

\section{May}

- MIRA launches its online tax payment system

\section{June}

- Enforced revenue collections reach Rf2 billion

\section{June}

- Online Filing and Payment Regulation gazetted

\section{July}

- Maldives Tax Academy established

\section{July}

- Addu Branch commences operations

\section{September}

- Fonadhoo Collection Centre opens

\section{October}

- Nilandhoo Collection Centre opens 


\section{October}

- Green Tax Regulation gazetted

\section{November}

- Green tax begins

\section{November}

- President ratifies the fourth amendment to the GST Act conferring GST-exempt status on day care services 27 December

- Eydhafushi Collection Centre opens 


\section{CHAPTER 1 Introduction}

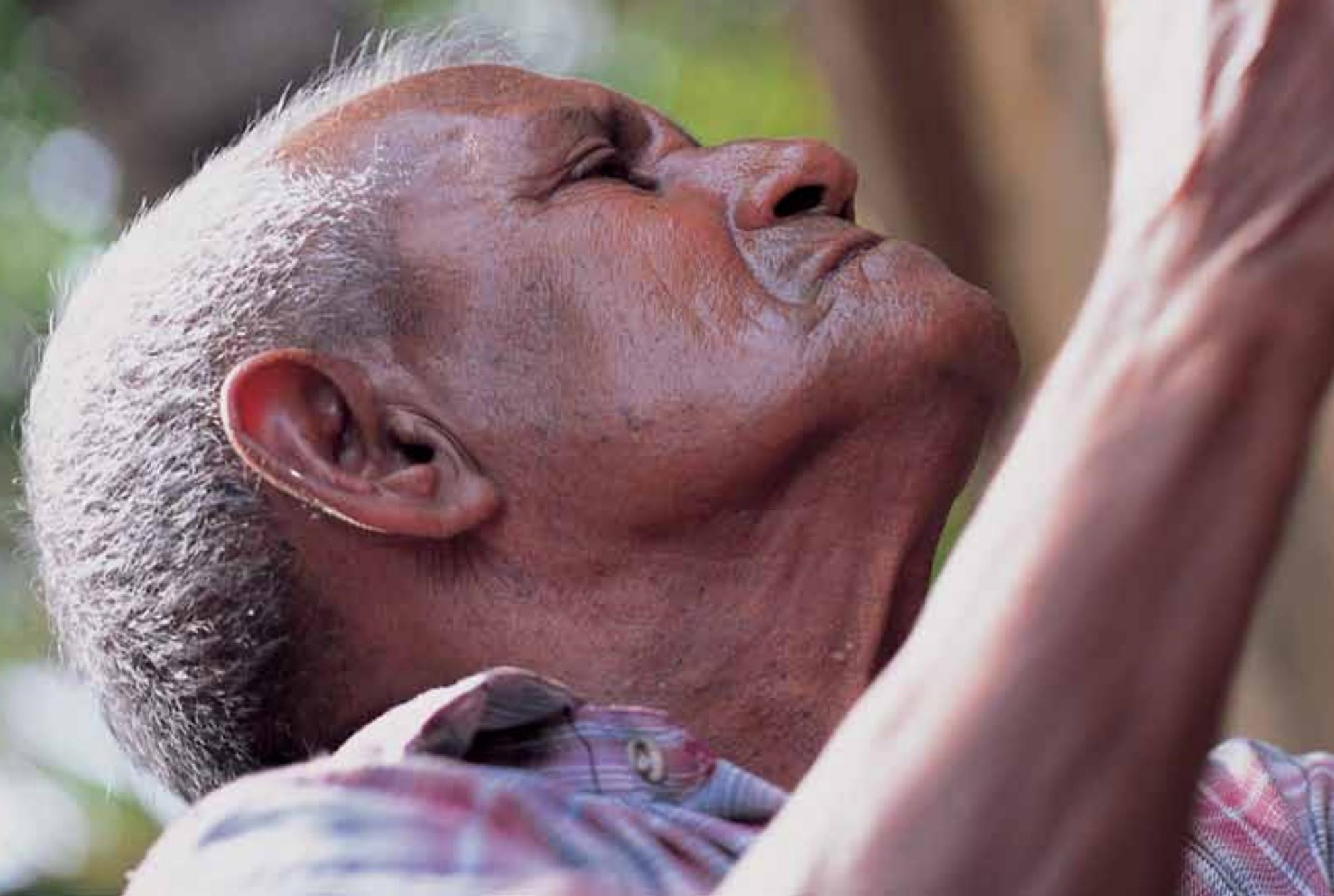




\section{BACKGROUND}

The Republic of Maldives is a small island Islamic nation, which straddles the equator, in the Indian Ocean. It is located approximately 450 kilometers $(\mathrm{km})$ southwest of mainland India. It is an archipelago made up of 26 natural atolls (divided into 20 administrative atolls), comprising around 1,190 islands, of which 188 are inhabited and 105 are tourist resort islands. Maldives is $820 \mathrm{~km}$ long and $120 \mathrm{~km}$ wide, and covers about 90,000 square kilometers $\left(\mathrm{km}^{2}\right)$, of which only $298 \mathrm{~km}^{2}$ (or $0.3 \%$ ) is land. Its highest point is a mere 2.4 meters above sea level.

The September 2014 Census revealed that the total resident population in Maldives was 402,071, of which 338,434 (84.2\%) were Maldivians and 63,637 (15.8\%) were foreigners. There were 227,749 males (56.6\%) and 174,322 females (46.4\%). The population has grown at an annual compound rate of $4.3 \%$ since the previous census in 2006. While the population is dispersed over the 188 inhabited islands, 153,904 people (or just over $38 \%$ of the total population) reside in the capital city, Male'.2 The archipelagic nature of the geography of Maldives, coupled with its small population scattered across distant atolls, results in high per capita service delivery costs. This situation poses challenges, which require extraordinary efforts to increase revenues to fund those services.
The Maldives economy began to develop during the presidency of Maumoon Abdul Gayoom (1978-2008). The average economic growth rate during $1980-2000$ was $7.2 \%$ per annum, primarily on the back of development of the tourism industry and, to a lesser extent, fishing and construction. Real gross domestic product per capita has grown from $\$ 908$ in 1989 to $\$ 5,036$ in 2014, now the highest in South Asia. In 2011, Maldives was elevated from a leastdeveloped country to a middle-income country under the United Nation's classification of countries. However, although Maldives has one of the lowest poverty rates in South Asia, there are wide regional disparities, together with relatively high inequality in the distribution of income and wealth.

Despite Maldives, macroeconomic successes, the provision of public goods and services associated with its economic development has come at a cost to the government. Particularly as a consequence of the 2004 tsunami that severely impacted the country and the 2008-2009 global financial crisis (GFC), new sources of government finance needed to be found. These factors, together with a burgeoning tourism industry, provided an appropriate opportunity to introduce direct and indirect taxes into Maldives.

\section{TOURISM DEPENDENCY}

The largest contributor to the Maldives economy is the tourism sector. In 2015, the tourism industry accounted for approximately one-quarter of the country's gross domestic product (GDP) and for more than $80 \%$ of its foreign exchange earnings. ${ }^{3}$ Tourism also drives much of the activity in other sectors of the economy, such as construction, distribution, and transportation. Therefore, the performance of the tourism sector has a significant impact across the whole economy.
Since Maldives first opened its doors to tourists over 40 years ago, the tourism industry has experienced exceptional and continued growth. The annual compound growth rate in operational bed capacity during the last 2 decades has exceeded $5 \%{ }^{4}$ This growth has been driven by the long-term trend in tourist arrival numbers. Figure 1 illustrates the annual compound growth rate in tourist arrivals of $7 \%$, during the period 1997-2015, when arrivals rose from 365,563 to $1,234,248 .^{5}$

2 National Bureau of Statistics, Maldives Population \& Housing Census 2014-Statistical Release: 1 Population and Households, 2015, pp. 13, 30 and 31, at http://planning.gov.mv/nbs/wp-content/uploads/2015/10/Census-Summary-Tables.pdf

3 http://mma.gov.mv/Monthly\%20Statistics/may16.pdf and http://mma.gov.mv/mmr/AR15.pdf

4 Derived from Maldives Monetary Authority, Monthly Statistics, Vol. 17, March 2016, p. 3, at http://www.mma.gov.mv/documents/Monthly\%20 Statistics/2016/MS-Mar-2016.pdf, and Maldives Monetary Authority, Annual Report 2015, pp. 68 and 75, at http://www.mma.gov.mv/ documents/Annual\%20Report/2015/AR-2015.pdf

5 Derived from Maldives Monetary Authority, Monthly Statistics, Vol. 7(7), July 2006, Table 4, at http://www.mma.gov.mv/documents/ Monthly\%20Statistics/2006/MS-Jul-2006.pdf and Maldives Monetary Authority, Monthly Statistics, Vol. 17(1), January 2016, p. 7, at http://www.mma.gov.mv/documents/Monthly\%20Statistics/2016/MS-Jan-2016.pdf 
Figure 1: Annual Tourist Arrivals (1997-2015)

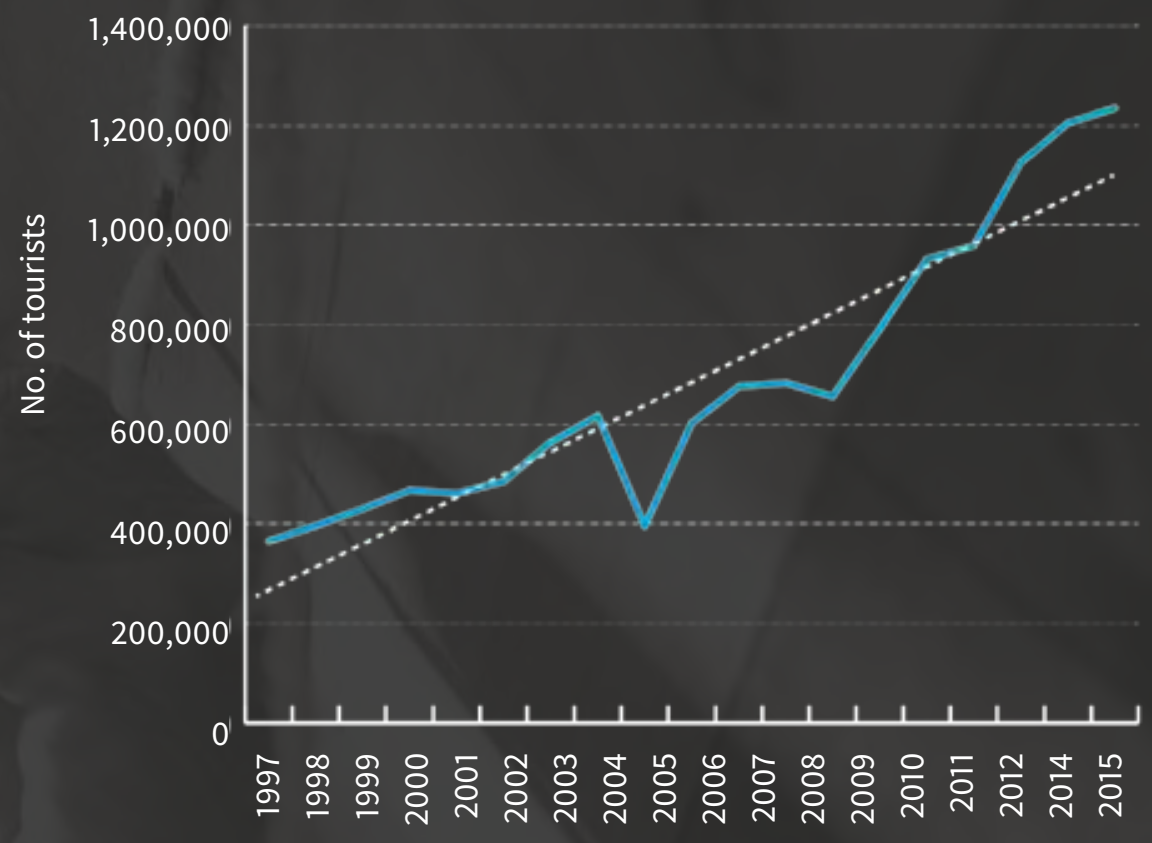

Year

Source: Author.

\section{TAX REFORM}

For most countries, government expenditure, to the extent that it is not financed by borrowing, is funded through a broad range of taxes. But until 2011, the sourcing of government revenue in Maldives was far narrower than that adopted by other countries.

By the end of the first decade of the 21st century, the government was under considerable pressure to raise more revenue. By 2009, the government deficit had reached $20.5 \%$ of GDP. ${ }^{6}$ The government therefore implemented an ambitious tax reform agenda. Within a period of 9 months (from 1 January 2011 to 2 October 2011), Maldives introduced:

- a tourism goods and services tax (T-GST), which was repealed later in that period and replaced by a general goods and services tax (GST); and

- a business profit tax (BPT), a tax akin to an income tax on businesses.
These taxes were introduced as part of a wider economic recovery program led by the International Monetary Fund (IMF), which included specific support to tax reforms by the Asian Development Bank (ADB).

During the same year, the government also introduced into Parliament corporate profit tax (CPT) and personal income tax (PIT) bills, which were intended to replace the BPT.

No other country has embarked upon such wideranging tax reforms within such a short period and, in particular, implemented a general GST regime within only one month from the presidential ratification of the empowering law until its implementation, as Maldives did.

6 Derived from Ministry of Tourism, Tourism Statistics 2001, 2001, p. 6, at http://www.tourism.gov.mv/downloads/tourism_statistics_2001.pdf and Ministry of Tourism, Monthly Updates, December 2016, p. 2, at http://www.tourism.gov.mv/downloads/arrival_updates/2016/December.pdf 


\title{
66 Maldives is a small country, but developing fast. People complain about paying tax. They say, 'Why do we have to pay tax? It takes money away from us.' But it is reasonable to pay tax because, by paying, we are financing the development of the economy, so the tax will come back to us later in the form of higher incomes.

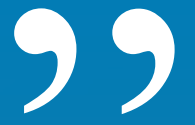

\author{
Fathmath Shaha Hassan \\ Business Studies student \\ Clique College, Male'
}

Prior to undertaking the reforms, Maldives had no central revenue-collecting authority. Instead, various government agencies were responsible for the collection of various fees, and many of these fees remained unpaid in full. Maldives Inland Revenue Authority (MIRA) was established in 2010 to implement the new T-GST, GST, and BPT laws, as well as take over the responsibility for collecting all nontax amounts payable to the government, other than customs duty (e.g., land lease rental payments, business permit fees, fines, etc.). Its broad mandate placed considerable pressure on the very limited resources available to MIRA. ADB technical assistance was able to provide expertise by way of tax specialists who, working closely with MIRA staff, were able to overcome capacity constraints.

Aside from the immediate revenue raising purpose of the imposition of new taxes, the introduction of BPT and general GST in the second half of 2011 were intended to broaden the tax base to reduce the government's revenue dependence on the tourism sector. That objective has been achieved to a limited extent, by taxing nontourism sector businesses (through the BPT) and the Maldivian public (through the general-nontourism-GST). 

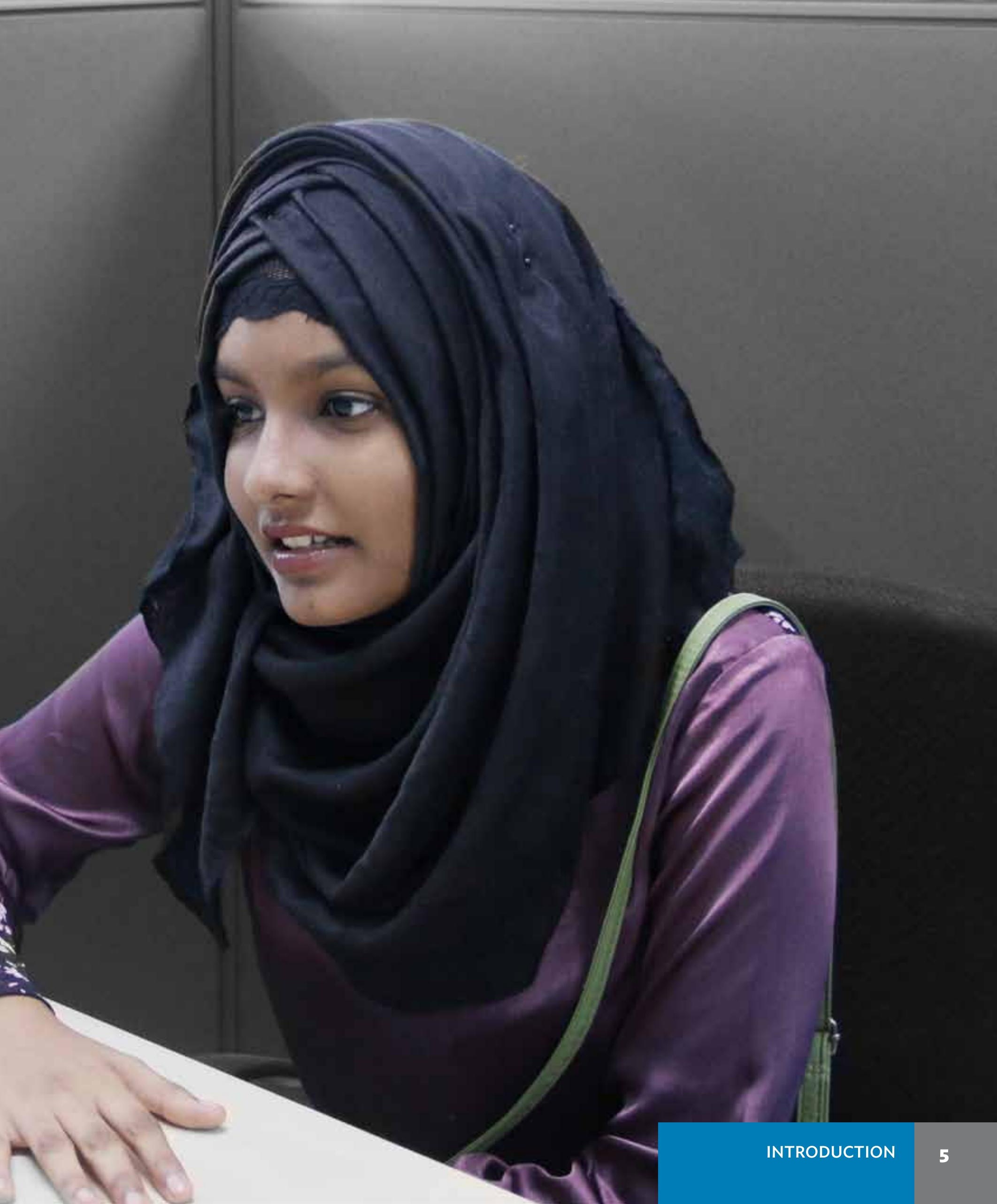


\section{COMPOSITION REVENUE}

Prior to 2011, the vast majority of public sector revenue in Maldives was generated by the two major indirect taxes-import duty and tourism tax-and land and resort rents. In addition, there were (and still are) several other imposts, such as bank profit tax, vehicle and vessel fees, and stamp duties. Additional public revenue was also generated through dividends from state-owned enterprises (SOEs), interest receipts, royalties, work permits and other administrative fees.
As Figures 2 and 3 demonstrate, there was only a modest change in the composition of the main components of government revenue between the beginning and the end of the first decade of the 2000s: import duties accounted for about one-third of total revenue in both 2002 and 2010, business and other property income remained at around $20 \%$, while land and resort lease rents fell from about one-fourth to one-fifth of total revenue, and tourism tax fell from around $15 \%$ to $10 \%$.

\section{IMPORT DUTIES}

Import duties are imposed at rates between $0 \%$ and $200 \%$. After accounting for several exemptions, historically, they have averaged around 13\% of the total declared customs values of imports. By 2010, import duties generated $33 \%$ of government revenue and grants (foreign aid), but declined thereafter as a result of the government's policy to reduce import tariffs as compensation for the introduction of general Goods and Services Tax (GST).

\section{RESORT LEASE RENTS}

Virtually, all land in Maldives is owned by the government. Tourist resorts are constructed on islands leased by resort owners from the government, which collects annual rental fees for the use of the land. Historically, depending on individual lease agreements, the amounts of lease rentals were either nominal or determined by competitive bidding based on a per bed basis. Prior to the 2011 tax reforms, land and resort lease rentals were the second most significant source of government revenue (after import duties). 
Flgure 2: Composition of Government Revenue (2002)

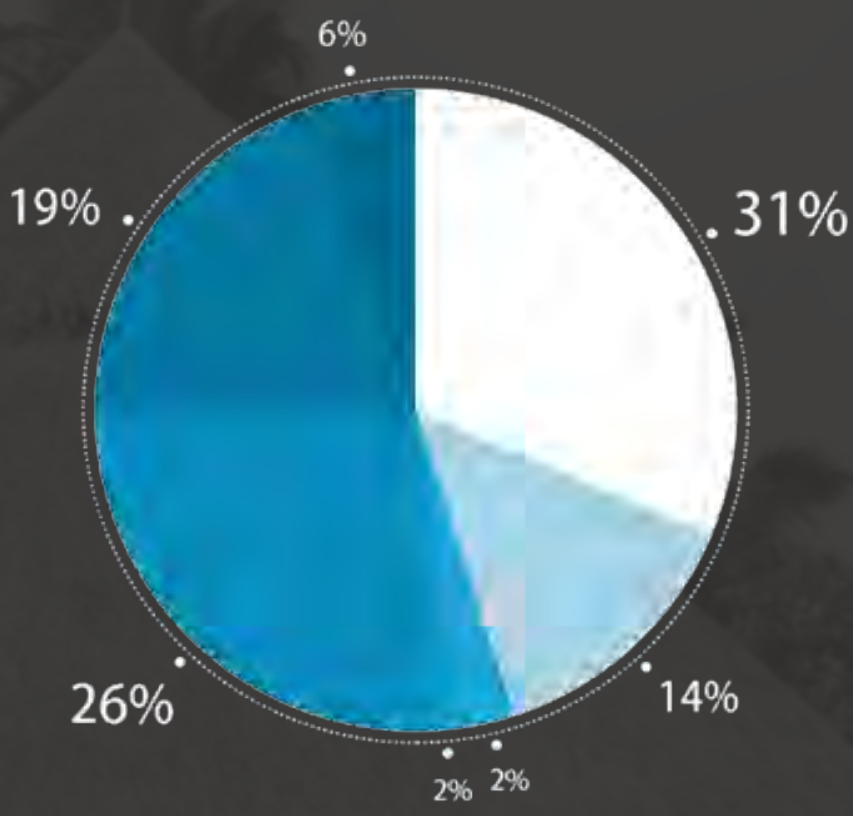

Import Duty

W Tourism Tax

D Bank Profit Tax

Other Fees and Taxes

Land and Resort Rents

Business and Other Property

Grants

Source: Author.

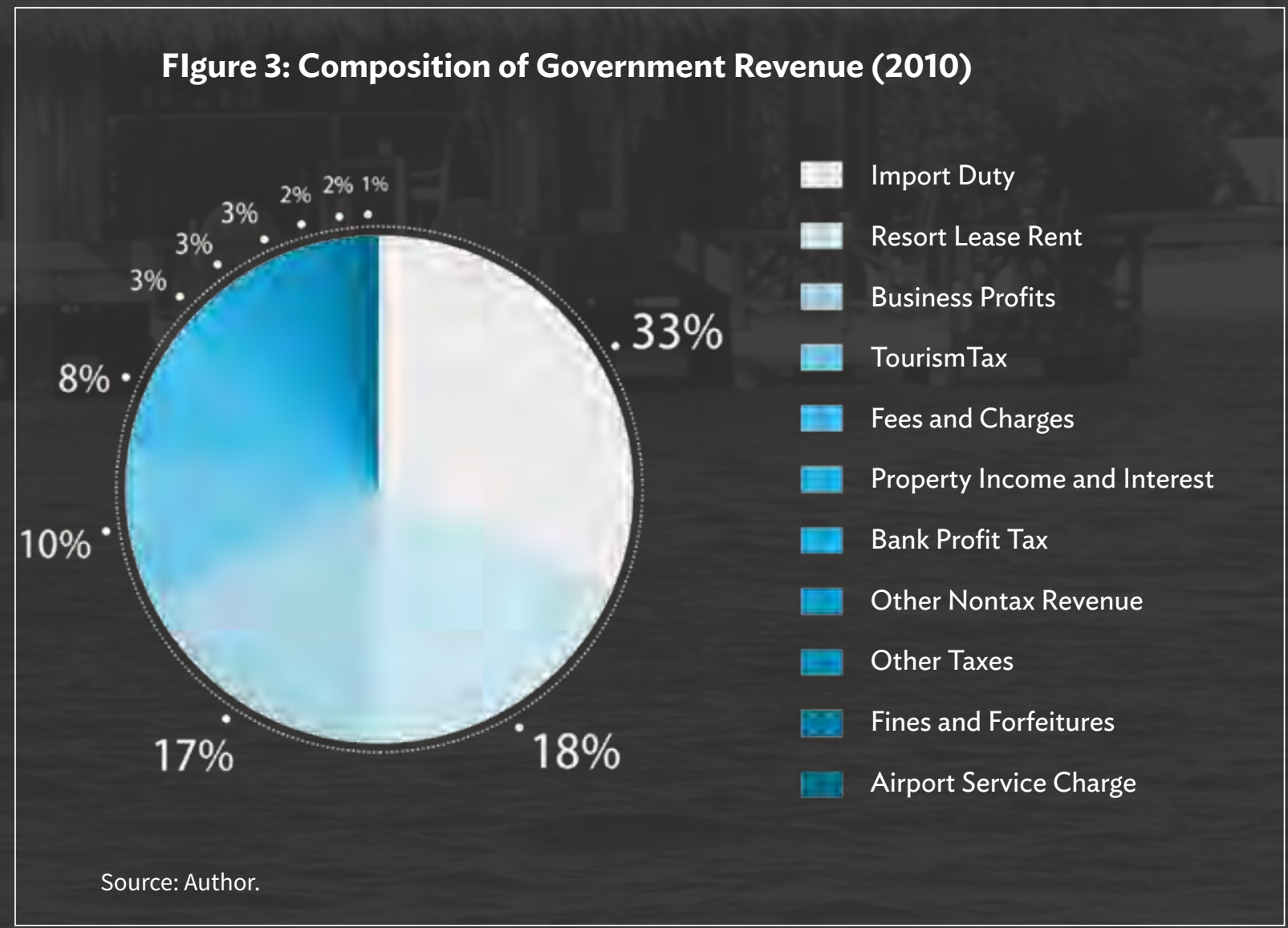




\section{BUSINESS PROFITS AND PROPERTY AND INVESTMENT INCOME}

Business and property, and other investment income remained relatively constant over the decade (19\% of total revenue in 2002, cf. $20 \%$ in 2010). Business profits comprise dividends from SOEs, rents from government-owned buildings, proceeds from sales of government assets, and interest on loans.

\section{TOURISM TAX}

One of President Gayoom's priorities when he came into office in November 1978 was to establish the National Planning Agency (NPA). This was done in December 1978. Part of the NPA's remit was to examine ways to increase government's revenue. The President (who was also the Minister of Finance and Treasury) and his cabinet, seeing the fledgling tourism industry ${ }^{1}$ as a potentially lucrative source of government revenue, devised the country's tourism tax-colloquially known as a "bed tax"-which was collected from hotels and resorts. It was introduced in January 1979 at the rate of $\$ 3$ per registered bed per night. Later in 1980 , the rate was changed to $\$ 4$ per tourist per night. In 1988, the rate was increased to $\$ 6$ per night, then ultimately to $\$ 8$ per night in 2004 .

There were 15 resorts with about 1,200 beds at that time.
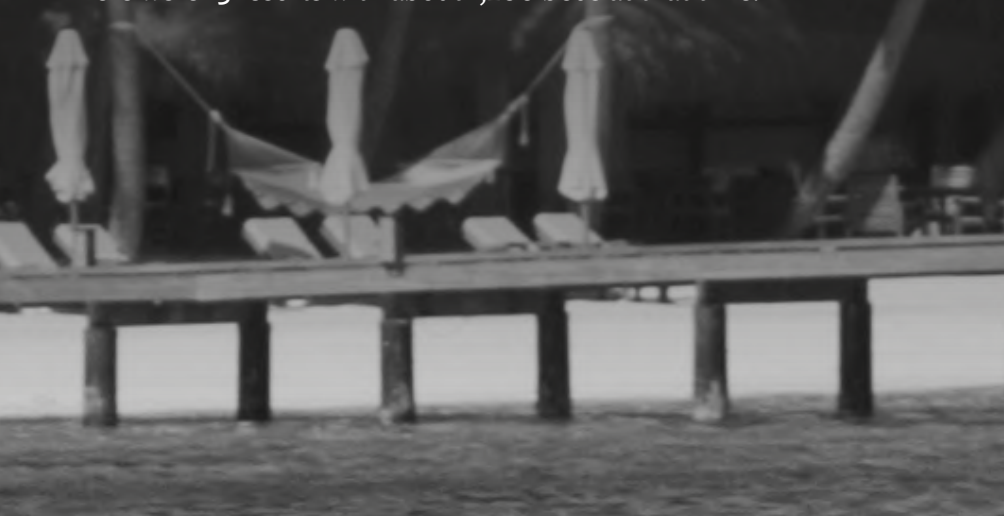
Figure 4: Tourism Tax (1980-2015)

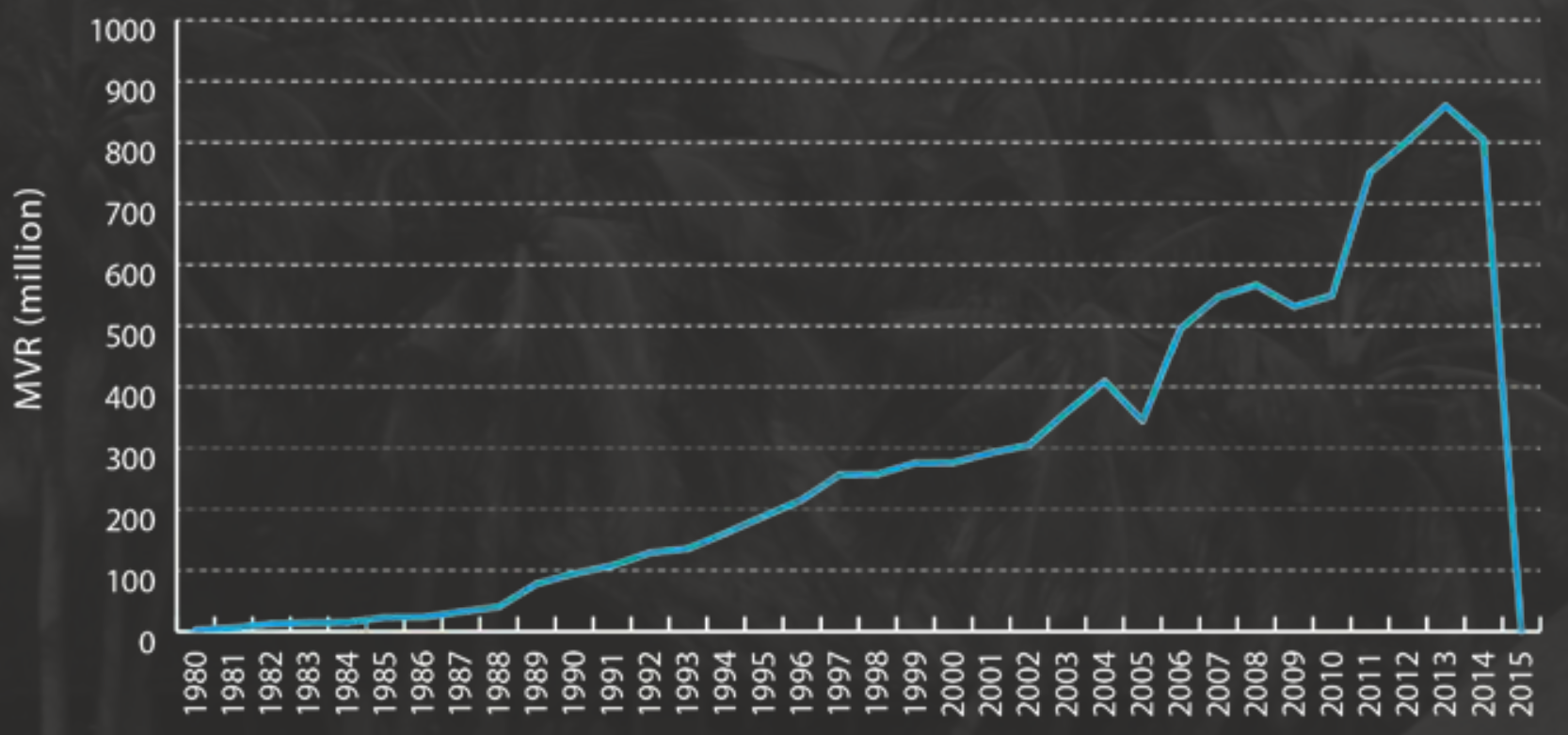

Year

Source: Author.

Figure 4 shows that the decision to introduce a tourism tax was a profitable one for the government. The tax collection was commensurate with the growth of the tourism industry. The annual compound rate of growth in tourism tax collections from 1980 to its peak in 2013 was in the order of 13\%. Nevertheless, despite the growth and rate increases, the percentage contribution of tourism tax to total government revenue had been on a long-term decline since peaking at around $14 \%$ in the mid-1990s. Tourism tax generated only $5.4 \%$ of all government revenue and grants in 2014, ${ }^{2}$ when it was abolished.

\section{BANK PROFIT TAX}

Before the introduction of BPT, there was only one direct tax in Maldives: the bank profit tax. The Bank Profit Tax $\mathrm{Act}^{3}$ was ratified by the President on 27 June 1985. Collection of the bank profit tax commenced officially in 1986. This tax still operates concurrently with the BPT. ${ }^{4}$ All seven banks currently operating in Maldives pay a bank profit tax at the rate of $25 \%$ on their taxable profits, which are calculated in accordance with Section 9 of the Bank Profit Tax Regulation. The rate was increased from $20 \%$ to $25 \%$ in 1991.

2 This percentage is for the period 1 December 2013 to 30 November 2014 (but excludes measures for February 2014) because the tourism tax effectively ended on 1 December 2014. Legislation was originally passed to terminate tourism tax on 31 December 2013, but pressure on State revenue resulted in its extension for another 11 months. However, tourism tax was not collected in February 2014 due to a delay in Parliament passing the relevant legislation to empower its collection in 2014.

3 Law Number $9 / 85$.

4 Banks pay a bank profit tax and are exempted from paying BPT. 


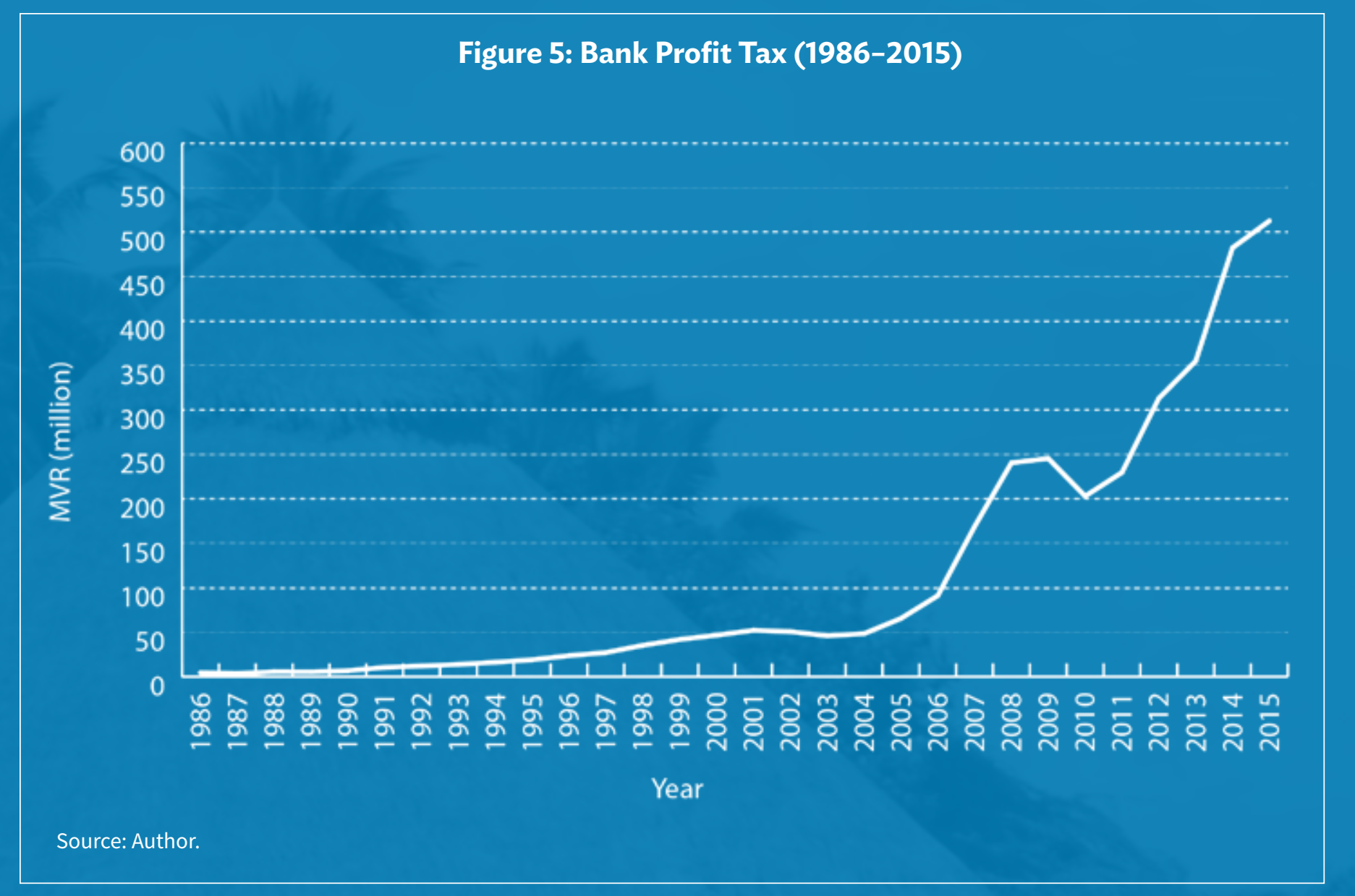

Figure 5 indicates that the bank profit tax has also been a growing source of revenue, particularly since 2004. However, the revenue generated by the bank profit tax has always been relatively insignificant, never accounting for more than $5 \%$ of total government revenue.
With government expenditure increasing at an annual compounding rate of more than $17 \%$ from $1986-2015$, all of these sources proved inadequate to meet the government's growing expenditure needs. A broader tax base was necessary.

\section{IMPERATIVES FOR REFORM}

Since the late 1980s, the International Monetary Fund (IMF) had been encouraging Maldives to diversify its tax revenue sources and reduce its dependence on the tourism sector. But other than tinkering with tax revenues during the 1990 s (e.g., by increasing airport tax from $\$ 7$ to $\$ 10$ in July 1993 and, in June 1992, introducing residence permit fees for foreigners living in Male'), little attention was given to broadening the tax base until the 2004 tsunami and 2008-2009 global financial crisis (GFC), both of which had a major adverse impact on the tourism sector. Those events sharply brought into focus the need to broaden the country's tax base in order to stabilize the source of public revenue by reducing the vulnerability of the government's fiscal position to domestic and external shocks, and to facilitate tariff reform. Since 2004 , rapidly increasing government expenditure-partly attributable to tsunami recovery efforts and partly to the government's otherwise expansionary fiscal policy-created widening budget deficits, which are still ongoing. 
In 2008-2009, while the country was still recovering from the effects of the tsunami, it then felt the effecs of the financial crisis. The GFC drove the economy into recession. Contraction within the tourism, fisheries, and construction sectors during that period resulted in an overall negative gross domestic product growth rate of $-3.6 \%$ in 2009 . Government revenue and grants shrank by $23 \%$ in 2009 as a result of lower customs duty collected from fewer imports, lower tourism tax collections from fewer tourist arrivals, and postponed tourist resort lease rental payments from embattled tourist resort projects. The government faced an unsustainable fiscal deficit. Action needed to be taken to address the continued increase in public debt, which was heading toward $97 \%$ of gross domestic product.

These developments occurred at the time of constitutional reforms under the new democratic Parliamentary system of government, which made improved public service delivery paramount for elected officials. Together, these elements created the "perfect storm," which paved the way for political support to break vested interests and support the introduction of a modern tax system.

\section{Box 1: Broader Reforms under the Economic Recovery Programme}

The 2004 tsunami and the 2008-2009 global financial crisis also served to concentrate the government's efforts to strengthen institutional economic management in Maldives. The report and recommendation of the President of the Asian Development Bank on the proposed program loan, technical assistance loan, and technical assistance grant to Maldives for the Economic Recovery Program $^{\mathrm{a}}$ stated that the country's fundamental problems included "a narrow and concentrated economic base, an inelastic taxation system, continued subsidization of social services, a rapidly growing civil service, and the lack of a clear strategy for the divestment and privatization of [stateowned enterprises]. In addition, human resource capacity constraints, especially at mid- to low-level, including government functionaries, have made effective implementation of development assistance projects difficult."

The 2009 Economic Recovery Program under Technical Assistance from the Asian Development Bank was part of a broad emergency program to support the the Government of Maldives, which was supplemented by several international financing facilities, including an International Monetary Fund Stand-By Arrangement. Among a range of efforts to create economic stability and to support economic growth, this program buttressed initiatives to broaden the tax base and to strengthen internal audit functions in government organizations.

\footnotetext{
a ADB. 2009. Report and Recommendation of the President to the Board of Directors: Proposed Program Loan, Technical Assistance Loan, and Technical Assistance Grant to the Republic of Maldives: Economic Recovery Program. Manila.
}

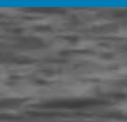

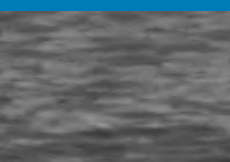
$2=$ 
During the 1980s, the IMF observed that the tax burden on the tourism sector had reached its limit. The IMF then estimated that government taxes on tourism services (comprising tourism tax, airport tax, resort lease rentals, and imports on goods and services consumed by tourists) made up about $35 \%$ of total spending by tourists. The IMF advocated for the introduction of a sales tax in Maldives, but this proposal was consistently resisted by the government on the grounds of its then limited administrative capacity.

By 1992, the government was also arguing that income tax was not feasible because of inadequate bookkeeping practices in the business sector. It also rejected property taxation based on market values because Maldives did not have a market in property rights. Nevertheless, a preliminary study was undertaken in 1992 to determine if property taxation could be imposed on an alternative basis, such as a presumptive tax based on the physical dimensions and other characteristics of property.

Targeted donor support for public finance management and revenue reform in Maldives was finally initiated by the Commonwealth Fund for Technical Cooperation (CFTC), followed by an IMF Fiscal Affairs Department tax policy mission in 1994, which formulated the strategy for revenue reform. Based on the findings of this mission, the IMF recommended the development and introduction of taxes on business profits and property rental values. Subsequent IMF missions in 1995 and 1996 produced draft legislation-BPT and Property Rental Value Tax (PRVT)-and recommendations to establish the Department of Inland Revenue (DIR), reporting to the Ministry of Finance and Treasury (MoFT). DIR was established in 1996, and in 1997, a Revenue Board was established to formulate and oversee tax revenue policies.
An additional follow-up mission by the IMF in 1997 continued the work begun by prior IMF missions. At this time, the IMF coordinated the technical assistance. During 1997 and 1998, CFTC consultants provided guidance to the DIR on how to administer the BPT and PRVT, and made recommendations for a revised organizational structure, work procedures, computer system requirements, and training on auditing and tax accounting. CFTC consultants also prepared drafts of the proposed tax administration legislation, manuals, related forms, taxpayer guides and other information material. A subsequent project by the CFTC in 2000 provided recommendations for the database management systems needed for the implementation of the BPT and PRVT.

In 2001, the Asian Development Bank (ADB) began a program to assist Maldives with its revenue reforms and conducted a country strategy and programme formulation mission in the country. This eventually led to technical assistance for revenue diversification in 2004. The technical assistance supported the development of tax legislation and administrative capacity within DIR, and capacity building of tax administration staff. Rather than pursuing the passage of the draft PRVT law, the government, for reasons of taxpayer compliance and tax administration efficiency, brought rental property income within the ambit of the BPT law instead.

Despite all of these efforts, and pressure from the Minister of Finance and Treasury in 2004 to "fast track" the implementation of the BPT to provide a new source of government revenue to meet state sector spending demands, the BPT Bill was not introduced into Parliament until December 2008, despite its anticipated commencement date of 1 January 2007, and did not become law until 18 January 2011. Thus, the gestation period for the Maldives BPT regime was a lengthy 17 years. 
Meanwhile, ADB continued its efforts to assist Maldives in its economic reforms and overhaul of its tax system. The key driver of policy actions that resulted in real progress of the economic reforms - and the overhaul of the Maldives tax system, in particular-was the ADB Economic Recovery Program (ERP), implemented in 2009. This $\$ 34.5$ million program produced greater fiscal space in the government's budget and financial flexibility via direct support for a more diversified tax base. Other important components of the comprehensive reform program included rationalized expenditure programs, better debt management, more efficient privatization of state-owned enterprises, and a deepening of the financial market with the issuance of treasury bills and bonds.
In 2011 and 2013, ADB provided Maldives with extended technical assistance to help it develop a revenue administration management system to support tax collection through greater tax compliance and efficient tax management. With support from the Japan Fund for Poverty Reduction, ADB also extended technical assistance to enhance MIRA's capacities in tax policy and tax audit. Much of the success of the ERP and technical assistance initiatives rests with the expertise of ADB's South Asia Department.

\section{Lessons}

1. Recognize tax revenue reform requirements at a political level on a timely and expeditious basis.

2. Take decisive action to introduce tax reforms once the need for them is recognized.

3. Deferral of implementation of tax reforms to address increasing budget deficits results in more pain later. 


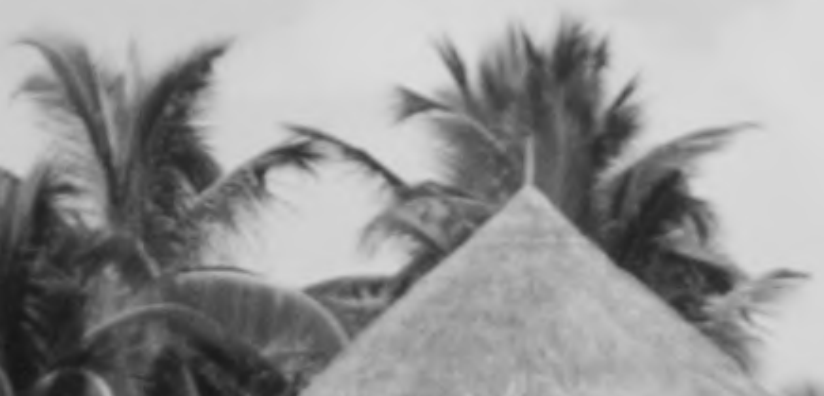

(a)

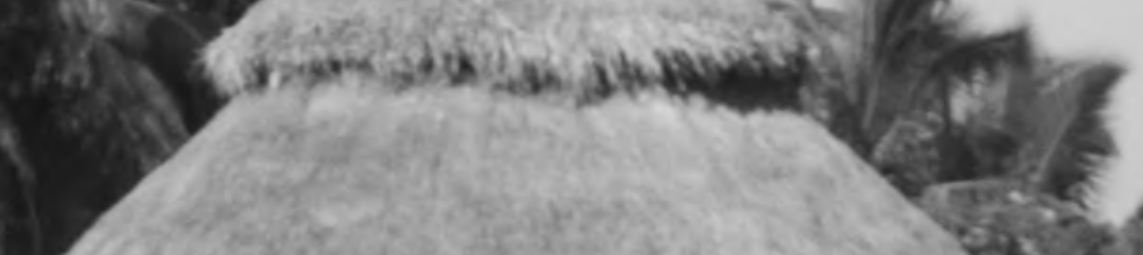

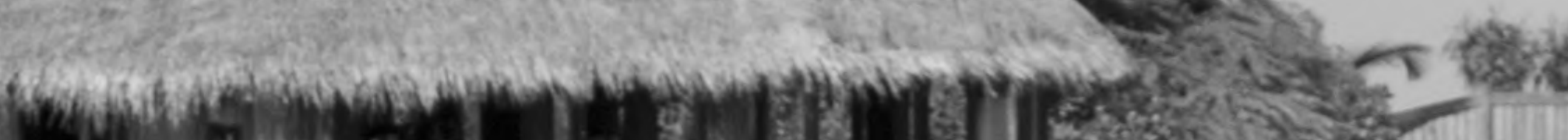

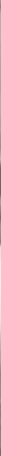

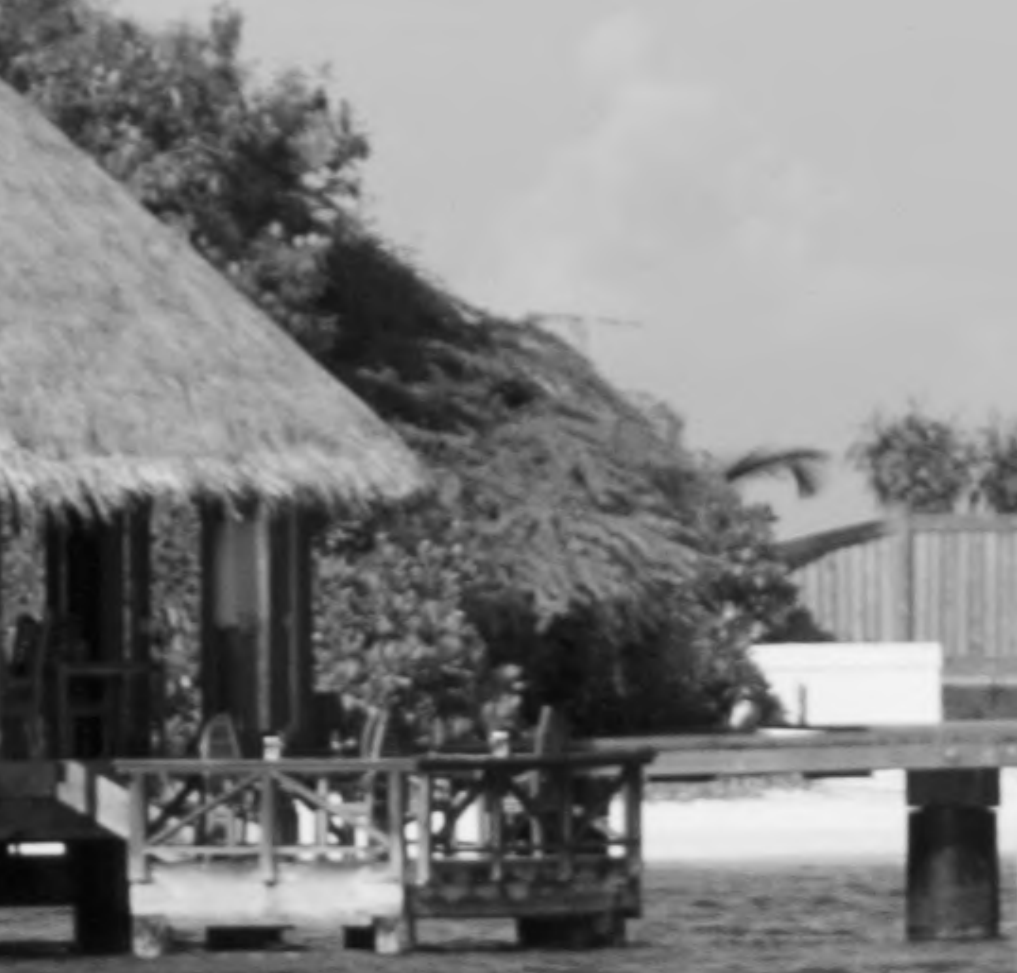


CHAPTER 3

\section{Introduction of New Taxes}

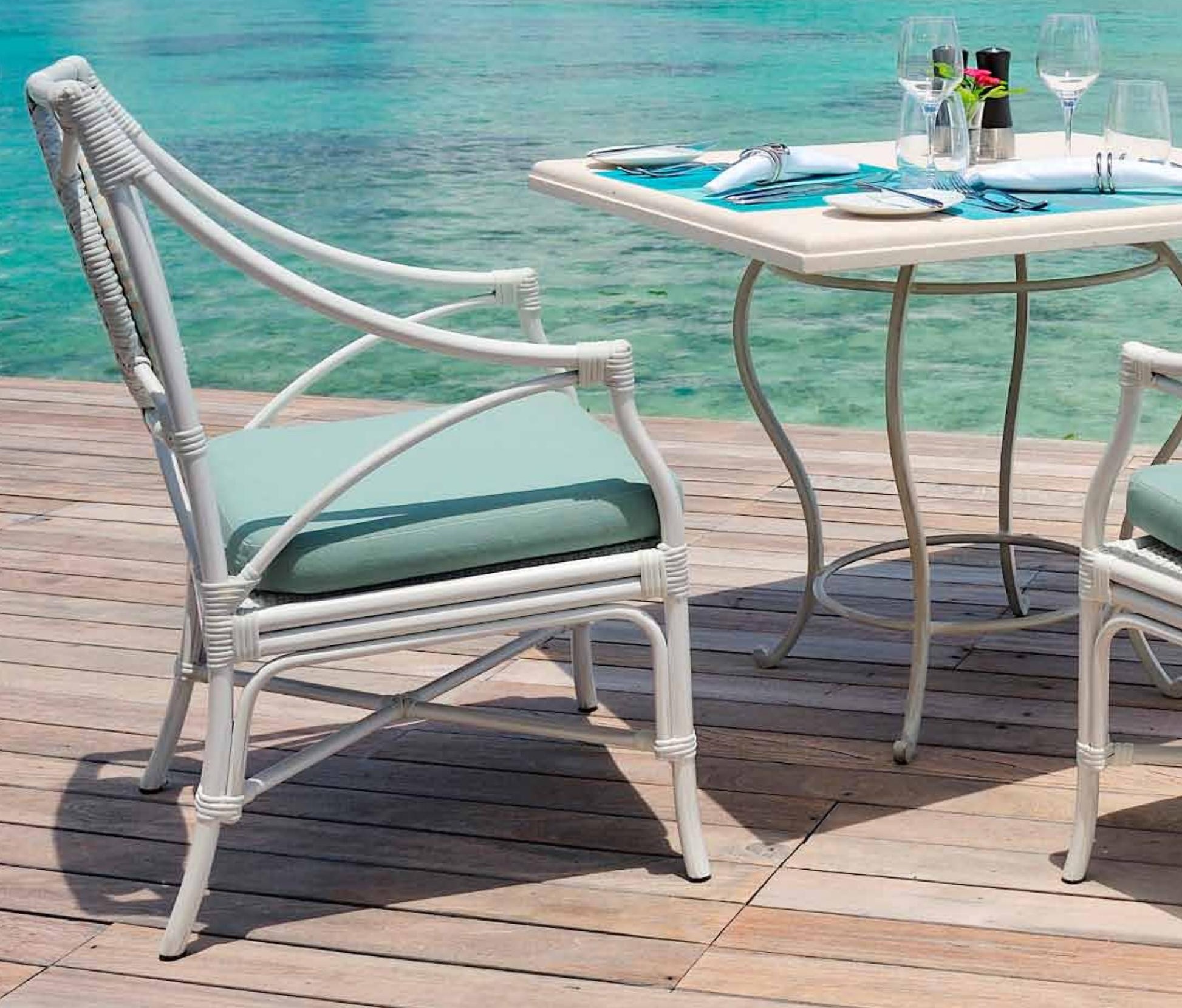



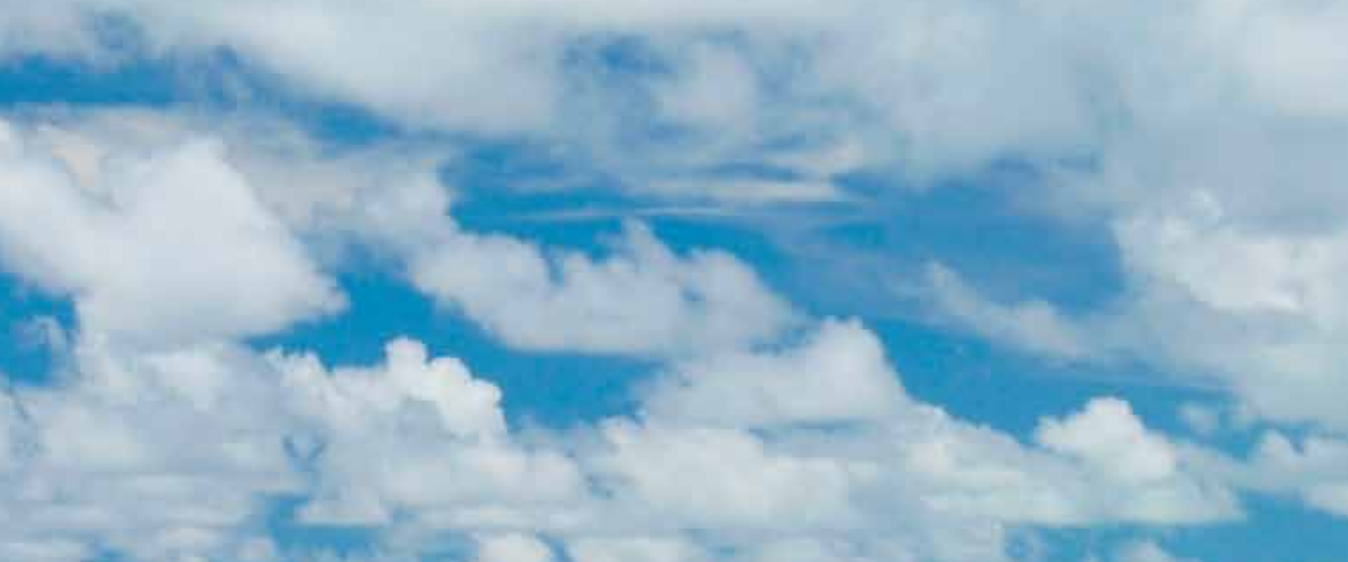

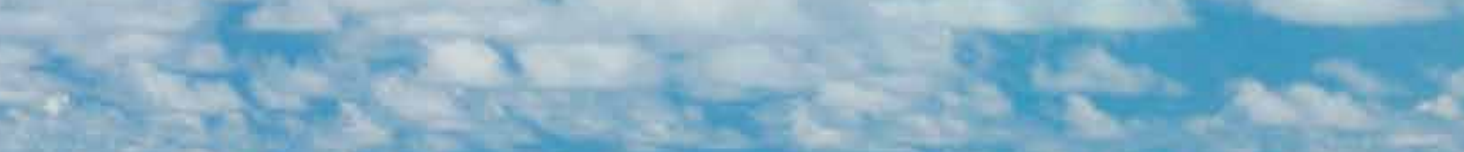

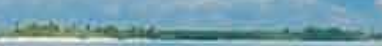

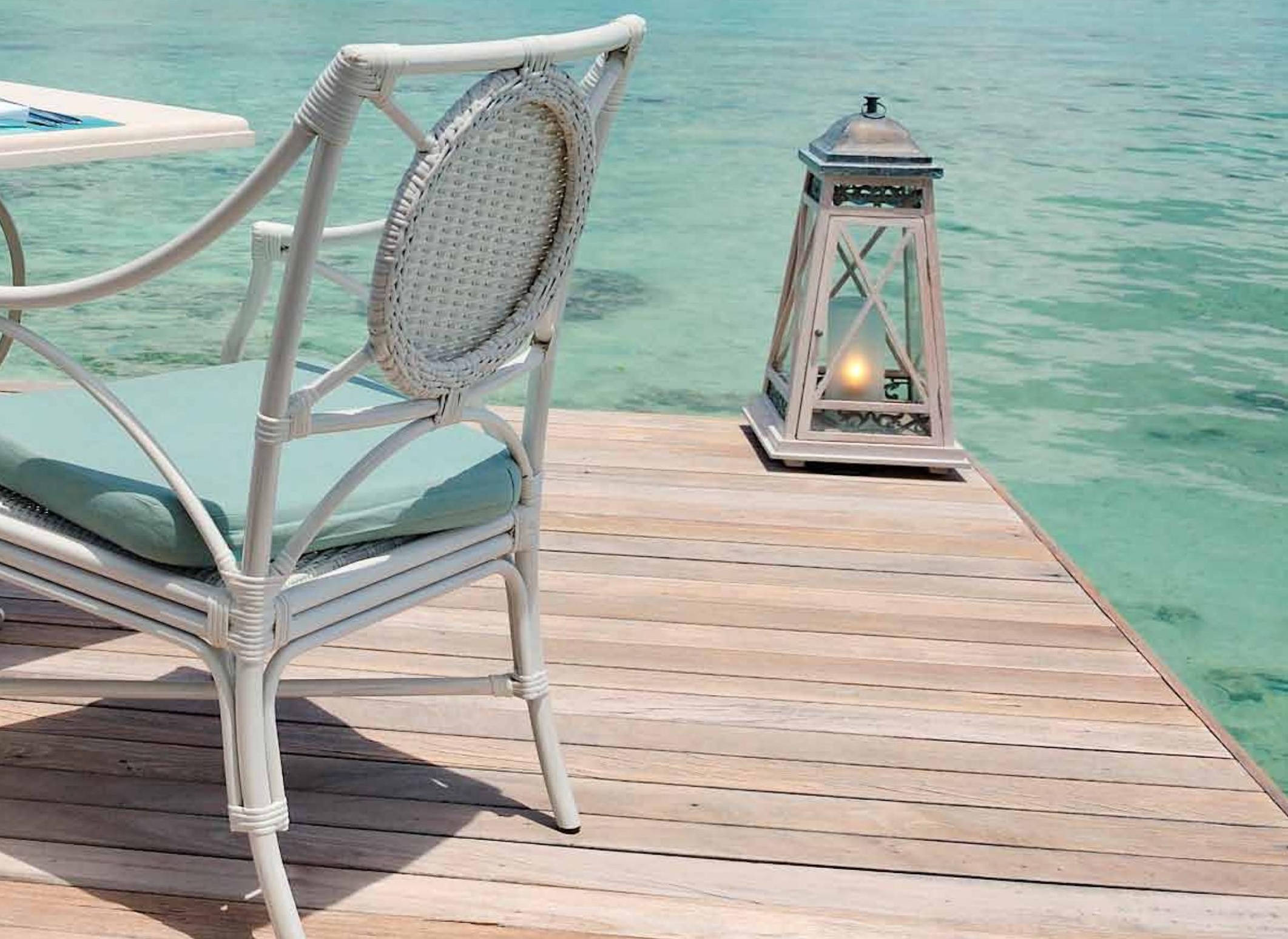




\section{POLITICAL EVOLUTION OF TAX REFORM}

After the long period of preparatory work on the Business Profit Tax (BPT) law, the introduction of new taxes began after the change of government in 2008. Figure 6 illustrates the period of intensive reform in 2010 and 2011, followed by a period of consolidation of the new laws. It was not until 2014 before the next new tax, the "green tax" was enacted. That tax, which is, in essence, a reincarnation of the tourism tax, did not become operative until 1 November 2015.

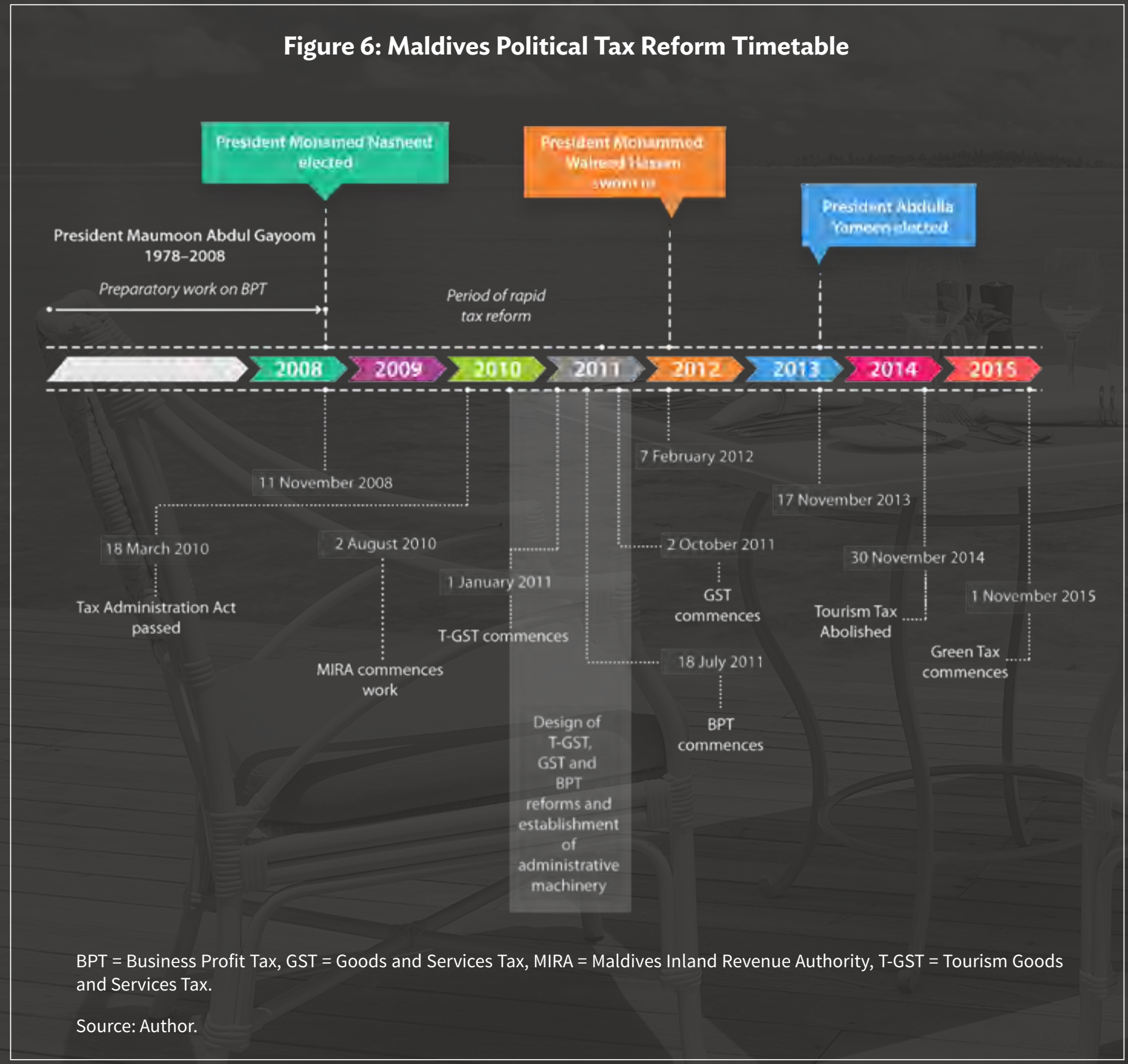




\section{INTRODUCTION OF NEW TAXES}

In 2009, the new government was determined to realize its ambitious programme of reforms to improve the state of public finances, by reducing expenditure and increasing revenue. There was a need to develop a larger, more elastic and stable tax base in the country. The Maldives tax structure was outdated: its inflexibility-arising from its almost total dependence on the tourism sector-rendered it incapable of responding to both domestic and external shocks. Thus, 2011 marked the beginning of the modern tax system in Maldives-a system that was to have a significant impact on the state's revenue collection.

The main aims of the new fiscal policy were to achieve a smaller, more efficient public service; institute a reliable source of tax revenue; improve institutional arrangements for fiscal policy; and reduce the role of the State in the economy. All these were to be achieved while effectively protecting vulnerable groups. This plan needed donor support, given Maldives' limited domestic resources. Considering the effect of the global financial crisis and the legacy of past fiscal policy, significant external financing was needed during the initial adjustment period.

Considerable budgetary support to Maldives came from the International Monetary Fund (IMF) but, like much IMF fiscal buttressing, it was not without strings attached. The financing was linked to the introduction of Tourism Goods and Services Tax (T-GST) and BPT. It was anticipated that BPT would be implemented in 2010. But there were delays in implementing the revenue elements of the reform program, which were putting the economic benefits of the program at risk. Continued deferrals of the introduction of the new tax measures threatened the financial support from the IMF.

Nevertheless, the government's timetable to raise additional tax revenue was demanding, although somewhat erratic: within a period of 16 months, T-GST legislation was introduced and repealed, BPT was introduced, a general Goods and Services Tax (GST) was introduced, a corporate profit tax (CPT) law was passed to replace BPT, but was not ratified by the President, and a personal income tax (PIT) Bill was introduced into Parliament. Maldives was unique in introducing such wide-ranging tax reforms within such a short period.

The tax laws that did come into being required supporting administrative regulations. Some of the statutes required subsequent amendments. These requirements created a hectic legislation drafting environment during the reform period. Figure 7 shows that no less than 25 tax legislation events occurred from 2010 to 2015.

These reforms, together with appointment of Maldives Inland Revenue Authority (MIRA) as the central collection agency for all (noncustoms) government dues, placed immense focus on MIRA and pressure on its resources. External technical assistance was required in a number of areas to develop the institutional capacity of the fledgling organization. 


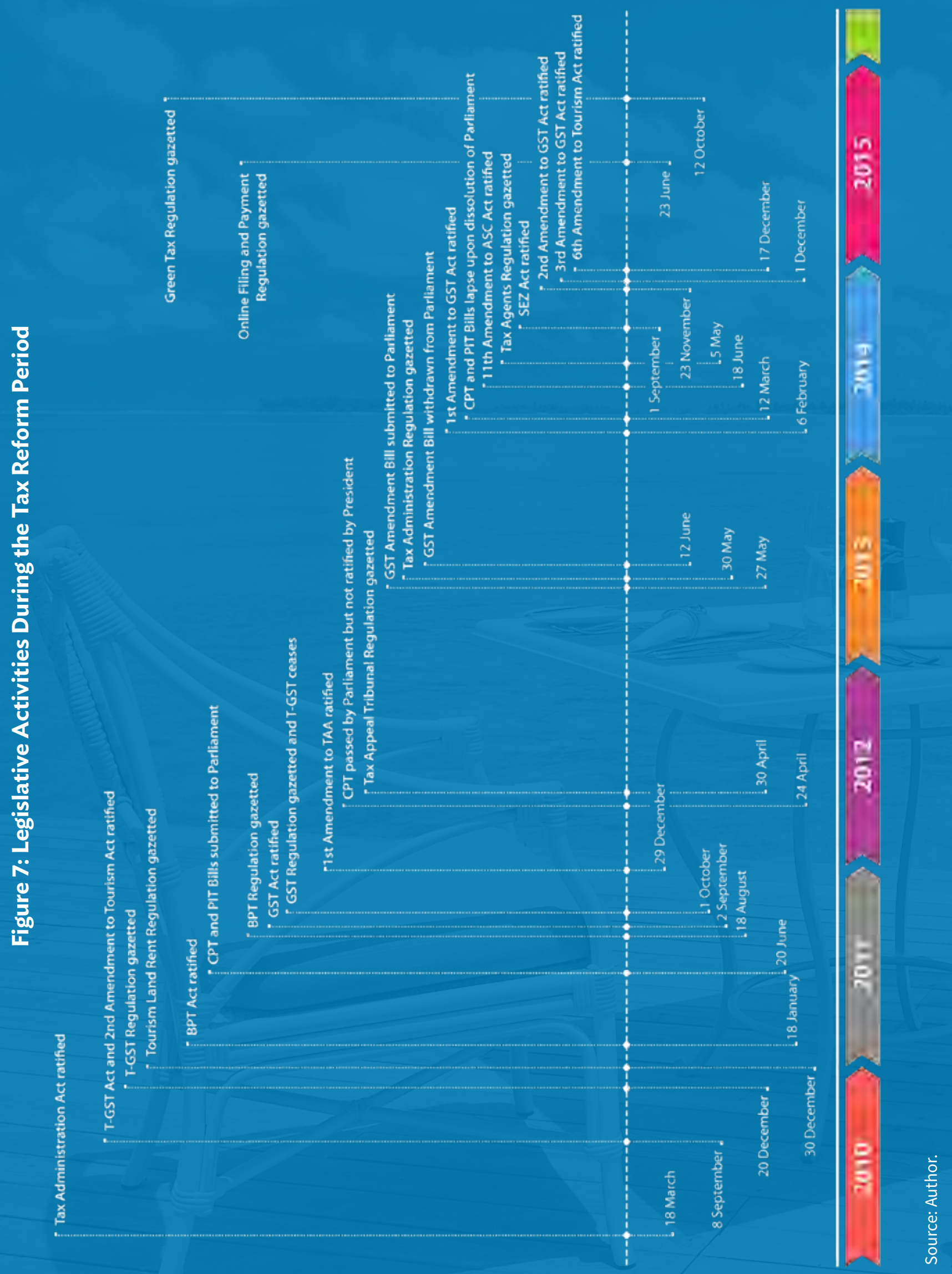




\section{BUSINESS PROFIT TAX}

As noted in Chapter 2, BPT had been on the tax reform agenda for a long time. In essence, BPT is a tax imposed on the profits of businesses, which are operated in Maldives by companies and noncorporate persons and entities. The first Rf500,000 of a business's taxable profits is exempt from tax. BPT is generally imposed at a flat rate of $15 \%$ of taxable profits, although Maldives-resident companies which derive all of their profits exclusively from sources outside Maldives are taxed at the rate of $5 \%$. BPT in respect of a taxyear (typically ending on 31 December) is payable in three installments: two interim payments for the year by 31 July and the following on 31 January, and a final payment on the later of 30 April or 6 months after balance date. ${ }^{1}$

In addition, certain payments made to nonresidents for services rendered by them, and for the right to use their intangible property are subject to a final withholding tax (WHT), imposed at the source at the rate of $10 \%$ of the gross amount of the payment to the nonresident. WHT is payable by the 15th day of the month following the payment to the nonresident. This regular monthly revenue is clearly advantageous to the government's cash flow.

\section{Box 2: Confused Commencement}

After the Parliament passed the Business Profit Tax (BPT) on 30 December 2010, it came into effect on 18 July 2011, or 6 months after the gazetting of the Act on 18 January 2011. However, section 41 of the BPT Act is ambiguous about whether the commencement of the Act was on 18 July 2011 or 1 January 2012, although the general assumption was that it was on 1 January 2012. Maldives Inland Revenue Authority requested a legal opinion on the commencement date from the Attorney General, and that opinion emerged in favor of commencement on 18 July 2011.

The point was important because of the government's deteriorating fiscal position: the sooner BPT commenced, the sooner the government could collect more taxes.

But the confusion over the commencement date also highlighted another issue. The major contributors in the Maldives economy are resort owners and other tourism operators. Many of them are foreign investors and operators. To make their business and investment decisions, they rely on clear and unambiguous commercial legislation to avoid the great fear of all businesses-uncertainty and its associated increase in risk.

Source: Author.

Sections 17 (d) and 24(a) of the BPT Act. 


\section{BUSINESS PROFIT TAX REGULATIONS}

MIRA drafts tax regulations authorized under the tax statutes, which it administers. Regulations are legally binding upon taxpayers. MIRA internal approval of regulations is required by the Technical Committee (which comprises MIRA's senior managers), and final sign off is made by its Board of Directors. ${ }^{2}$ These regulations are then approved by the Attorney General before gazetting.

Regulations are often circulated to government agencies and released to the public for comment, albeit typically there is little feedback from the public. More commonly, tax advisors and industry lobby groups, with particular interests in certain areas of taxation, make submissions on publicly released draft regulations. These comments are important because the legislation and regulation draftsmen are not experts in the fields to which the new law is to apply, and therefore do not necessarily appreciate all of the consequences of the law for the taxpayers concerned. Since taxpayers know their businesses best, their insights are valuable to ensure that the law or regulations which are ultimately passed are practicable. Such public consultation therefore also mitigates against the need for subsequent amendment to a statute or regulation. The public consultation process has resulted in amendments to draft regulations to respond to the public's concerns.

The BPT Regulation facilitates the administration of the BPT Act. The BPT Regulation is a set of detailed rules designed to clarify those matters and to facilitate the implementation of the parliamentary law.

The drafting process required the formulation of detailed procedures for the implementation of the BPT Act, and identification of areas of potential alternative interpretations of the Act and aspects of administrative difficulties.

The 18 July 2011 commencement date, referred to in Box 2, created a number of complications in drafting the BPT Regulation, since various provisions in the BPT Act appeared to be premised on a 1 January 2012 commencement date.

\section{Box 3: Writing Tax Depreciation Rules}

Drafting the Business Profit Tax Regulation required constructing a capital allowance schedule, which details categories of business assets and appropriate rates of depreciation for tax deduction purposes, together with depreciation recovery rules when an asset is sold or scrapped.

Since it was impractical to value assets held by businesses at the commencement of the Business Profit Tax regime on 18 July 2011-and even if the assets were capable of valuation, there were no valuers in Maldives to do the work-capital allowance calculations needed to be based on the cost price of assets.

Drafting this rule was complicated by the fact that businesses (small and medium-sized ones, in particular) typically did not retain records of the assets they held or the amounts they paid for them. It was therefore necessary to make a best estimate the cost price of the assets, often paid many years earlier, to determine the basis for the annual capital allowance deduction.

Source: Author.

\footnotetext{
Section 4(1) of the TAA.
} 


\section{PROPOSED CORPORATE PROFIT TAX AND PERSONAL INCOME TAX}

From April to May 2011, the compilation of the BPT Regulation was held in abeyance upon advice from the government that the implementation of the BPT Act was under review due to its proposed replacement by the CPT and PIT Acts, which were intended to broaden the tax base and to come into effect at the beginning of 2012. The CPT and PIT Bills were introduced into Parliament on 20 June 2011. During the April-May hiatus, MIRA resources were diverted to arranging for the implementation of the new legislative proposals (including the prospective general GST Act).

The CPT and PIT Bills were weaker than the extant BPT Act. Inadequate consideration was given to the obvious opportunities for the avoidance of tax on corporate profits. The bills were also complicated and would have resulted in additional taxpayer compliance costs and administration inefficiencies and, therefore, higher tax administration costs. For example, the bills contained:

- a multi-rate corporate tax, something that most developed countries abandoned many years ago, partly because of the tax planning and avoidance opportunities that multiple rates create;

- extensive progressivity in the proposed individual income tax scale. Most countries nowadays attempt to flatten the scale, primarily to reduce "fiscal drag" and opportunities for tax avoidance;

- a diluted definition of "royalty;" and

- no withholding tax on payments to nonresidents.

Most likely, it would have been left to MIRA to author regulations to provide clarification and to fill the gaps in the legislation to the extent legally possible (as had been the case with T-GST, BPT, and GST).

In June 2011, the government decided not to pursue the CPT and PIT bills and instead proceed with the BPT regime, at which point further substantive work resumed on the BPT Regulation and the BPT public awareness programme. The BPT Regulation was finalized and released for public consultation on 8 June 2011. After a number of changes were made, the BPT Regulation ${ }^{3}$ was gazetted on 18 August 2011, and took effect on that date. ${ }^{4}$

If the CPT and PIT bills had been passed in the form in which they were introduced into Parliament, it would have resulted in a significant undermining of tax revenue collection. As it happened, the bills lapsed at the end of the 17th Parliament (2009-2014), on 12 March 2014.

\footnotetext{
Regulation Number 2011/R-35.

4 Section 77 of the BPT Regulation.
} 


\section{DIRECT CONSEQUENCES OF INDECISION AND CONFUSION}

One adverse revenue consequence of the period of indecision about whether the BPT regime would proceed was that the government decided to abandon the collection of the first interim payment of BPT, which was due on 31 July 2011. It collected only one interim payment on 31 January 2012, and the final payment on whichever was later between 6 months after a taxpayer's balance date or 30 April 2012.

An administrative complication arising from the decision to implement BPT from 18 July 2011 was the calculation of tax for the 2011 tax year. Unless a taxpayer prepared special purpose accounts for the period 18 July 2011-31 December 2011 (which was the exception, rather than the norm), the annual taxable profit for the period 1 January 2011-31 December 2011 was required to be apportioned in the ratio of 167/365 days. Similarly, the Rf500,000 taxfree threshold available to all taxpayers was required to be apportioned in the same ratio.

Moreover, only businesses that had balance dates from 18 July 2011 to 31 December 2011 were liable for tax in the 2011 tax year. ${ }^{5}$ This offered generous cash flow advantages to taxpayers with balance dates falling from 1 January 2011 to 17 July 2011, since their tax liabilities did not begin until the 2012 tax year and their tax payments were deferred accordingly.

\section{TOURISM GOODS AND SERVICES TAX}

The BPT had been in the making for several years. However, while it was still being finalized, the T-GST was introduced in 2010. T-GST was the first tax in the modern reform process to increase and stabilize the flow of public revenue. The T-GST Act ${ }^{6}$ was passed by Parliament on 26 August 2010. It was ratified by the President on 8 September 2010, and took effect on 1 January 2011. This legislative sequence produced a very tight 4 -month timeline to set up the implementation mechanisms, including the formulation of the T-GST Regulation by 8 December 2010 (as required by the legislation).?

T-GST was an indirect ad valorem consumption tax, imposed on most products and services sold to tourists by the tourism industry. The tax applied to room rates charged by resorts, hotels, picnic islands, guest houses, and tourist vessels, as well as goods and services sold to tourists by those businesses. T-GST also applied to domestic transportation of tourists, travel agency charges, and goods and services sold to tourists by dive centers, shops, spas, and water sport facilities at resorts, hotels, guest houses, and tourist vessels. It was imposed at a rate of $3.5 \%$ of the value of goods and services supplied to tourists.

The nominal $3.5 \%$ rate arose essentially from a compromise with the tourism industry, which was required to implement T-GST at such a short notice. However, because resorts had already agreed to annual fixed-price supply contracts with foreign tour operators, they could not pass the new T-GST impost onto guests immediately and thus were required initially to bear the tax themselves. Only for the 2012 tourist season (and thereafter) could T-GST be taken into account in fixing resort charges.

In addition to obtaining additional tax revenue, part of the reason for introducing T-GST was that tourism tax was regressive, and therefore imposed unfairly. At a flat rate of $\$ 8$ per person per night, tourists accommodated by the newly developing low-cost guesthouse industry

\footnotetext{
Section 8(a) (1) of the BPT Act.

Law Number 19/2010.

Section 56 (b) of the T-GST Act.
} 


\section{Lessons}

1. Clearly identify tax policy positions and roll them out in a systematic manner.

2. Write clear and unambiguous legislation.

3. Pass regular (ideally, annual) amendment acts to remedy statutory deficiencies and to combat previously unanticipated tax events and unintended consequences of the law.

4. Release proposed laws, regulations, and rulings for public consultation before finalization.

5. Ensure that proper transitional mechanisms are in place at the date of commencement of a new tax law.

bore a greater tax burden (in terms of tourism tax as a proportion of their accommodation charge) than guests accommodated in the traditional high-end resorts. The introduction of a uniform ad valorem T-GST was designed to remove that inequity.

As the timeframe for the implementation of BPT moved, MIRA's priorities and immediate needs changed. While BPT remained a priority for MIRA, the introduction of the T-GST, on top of the BPT, placed extraordinary strain on the time available to the staff, and necessitated extensive and urgent technical support, focusing on the development of internal procedures for administration and collection of the T-GST, and conducting staff training and public awareness programmes. 
A general GST replaced the T-GST on 2 October 2011. The GST was designed broadly along the lines of an IMF report issued in October 2010. The IMF had been advocating for the introduction of a general consumption tax, not only as a government revenue expansion and diversification measure, but also as a tariff replacement measure, particularly in the light of pressure on the tariff regime arising from Maldives' World Trade Organization commitments and the development of the South Asian Free Trade Agreement (SAFTA), which promotes regional free trade and tariff-reduction arrangements.

In June 2011, the Attorney General's Office issued a draft GST Bill, which required significant amendments. The GST Bill was introduced into Parliament on 20 June 2011. Some of the proposed amendments were not accepted and parts of the Bill were changed when it was before Parliament, which resulted in some implementation difficulties. The resulting GST Act was passed by Parliament on 29 August 2011, ratified by the President on 2 September 2011, and commenced on 2 October 2011.

In essence, the GST Act imposes a GST on the value of goods and services supplied by registered businesses at an initial rate of $3.5 \%$, applicable to both the tourism and the general sector of the economy. To enable a regular revenue flow to the government, GST is required to be paid to MIRA by the 28th day of the month following the month in which it is accounted for by the supplier of the goods and services subject to the tax.

The 3.5\% rate in the tourism sector was short-lived. From 1 January 2012 to 1 November 2014, the GST rate in the tourism sector increased three times. By contrast, the GST rate in the general sector increased once in that period-to $6 \%$ on 1 January 2012. Table 1 sets out the various GST rates, which have applied since the commencement of the regime.
These rate increases were driven by a growing fiscal deficit, and demonstrate that the (international) tourism sector is a politically more lucrative source of GST revenue than the (domestic) general sector. Development partners and experts believe that there is still scope to increase the tourism GST rate up to $15 \%$.

A draft GST Regulation was issued for public consultation on 24 September 2011, and the final version of the GST Regulation was gazetted on 1 October 2011.

A Bill to amend the GST Act to increase the tourism sector GST rate to 15\% from 1 July 2013 and to apply the GST to hitherto exempt telecommunication services was submitted to the Parliamentary Secretariat on 27 May 2013. However, on 12 June 2013, the Bill was withdrawn for lack of support and therefore was never formally introduced onto the floor of Parliament.

\section{Table 1: Goods and Services Tax Rates}

From 2 October to 31 December 2011 $3.5 \%$

From 1 January to 31 December 2012

From January 2013 (nontourism)

From 1 January 2013 to 31 October 2014 (tourism)

From 1 November 2014 (tourism)

$12 \%$

Source: Author. 


\section{Box 4: The Coinage Problem}

The roll-out of the Goods and Services Tax (GST) at the rate of 3.5\% across the whole economy in October 2011 created one particularly unforeseen practical problem: a shortage of coins to pay customers change in their transactions. For example, goods which cost Rf100 prior to the introduction of GST would typically be paid for with a Rf100 note, with no change required. Once GST commenced, those goods would now cost Rf103.50. Customers would commonly pay for them with Rf100 and Rf5 notes, requiring the vendor to give the customer change of Rf1.50 in coins. Frequently, because of lack of coinage, vendors would simply not give change to their customers (thus overcharging them), and blame the situation on the new GST regime.

To address the limited number of coins in circulation at the beginning of October 2011 (and complaints from customers), MIRA visited businesses and supplied them with 668,813 coins-obtained from the Maldives Monetary Authority (MMA) - worth Rf173,995.

Source: Author.

Given the speed of the passage of the legislation, and amendments to it made by Parliament, considerable effort was required in the unrealistically short lead time of 1 month (from ratification to implementation) to educate MIRA staff, businesses, and the public on the GST regime, compile the GST Regulation, and put taxpayer and tax administration systems in place to cope with a GST commencement date of 2 October 2011. By way of example, a draft GST Regulation was issued for public consultation on 24 September 2011, and the final version of the GST Regulation was gazetted on 1 October 2011.
Unsurprisingly, there was widespread misunderstanding about the imposition of GST, inconsistent application, and numerous technical issues arising as each business attempted to apply the law and regulations to its specific circumstances. Not the least of the problems was Maldives' cash-based economy and absence of business records - a vital ingredient of any GST regime. In any event, the time period for implementation of GST was, of course, far too short. 
66 The government wanted a reduction in import duties to reduce costs for small businesses, particularly new entrants, as import duty is an upfront payment. Also, the government wanted to eliminate the bed tax to help guest houses, as part of its policy to introduce more low-end tourist accommodations, which enables low- and middle-income earners to enter the lucrative tourism market in Maldives. We looked at a general GST to make up for the lost revenue. 99

Arshad Jameel

Managing Partner, Urban Stitch Partnership, Male', and

Consultant to President's Office (2008-2011) 


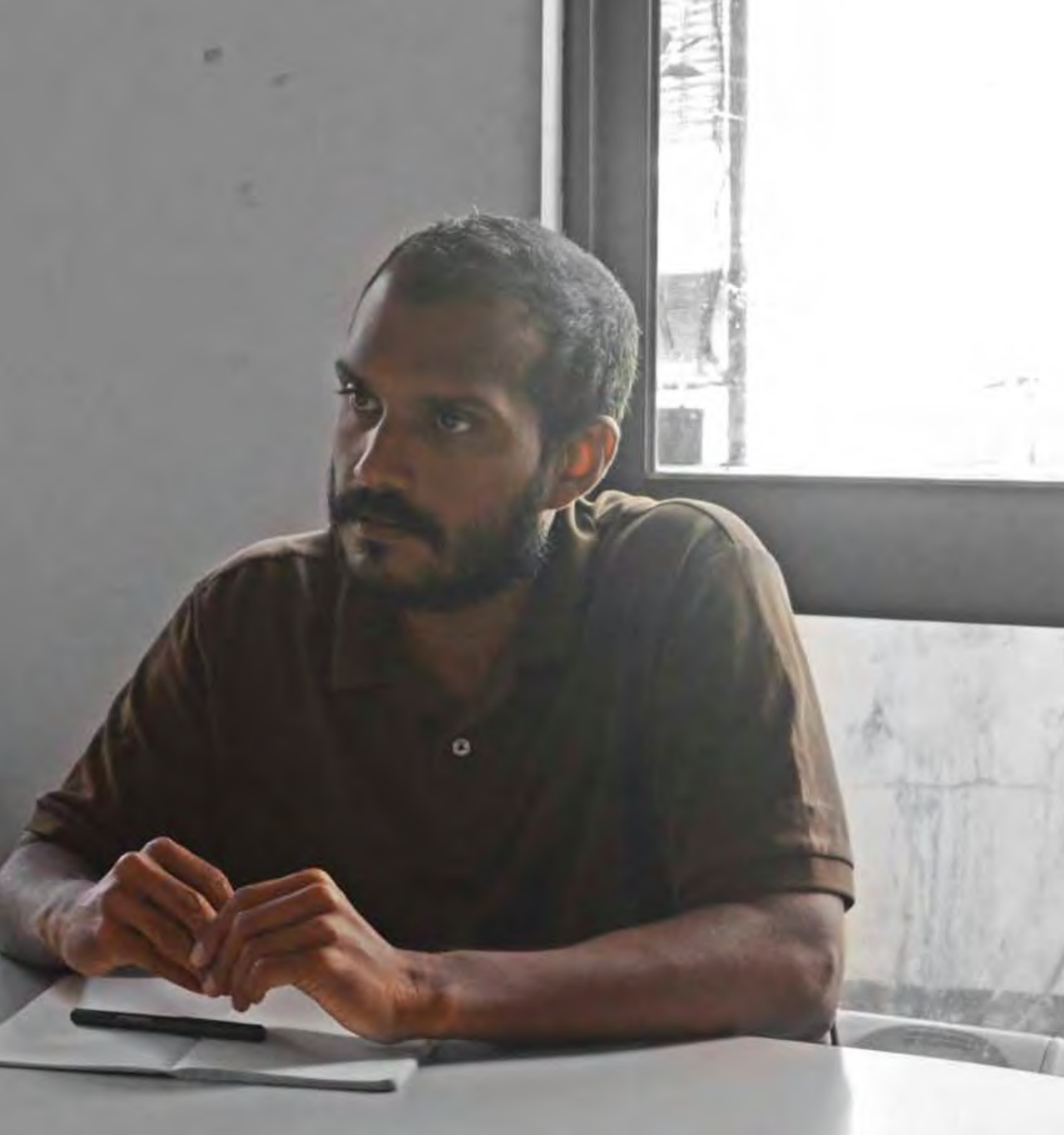




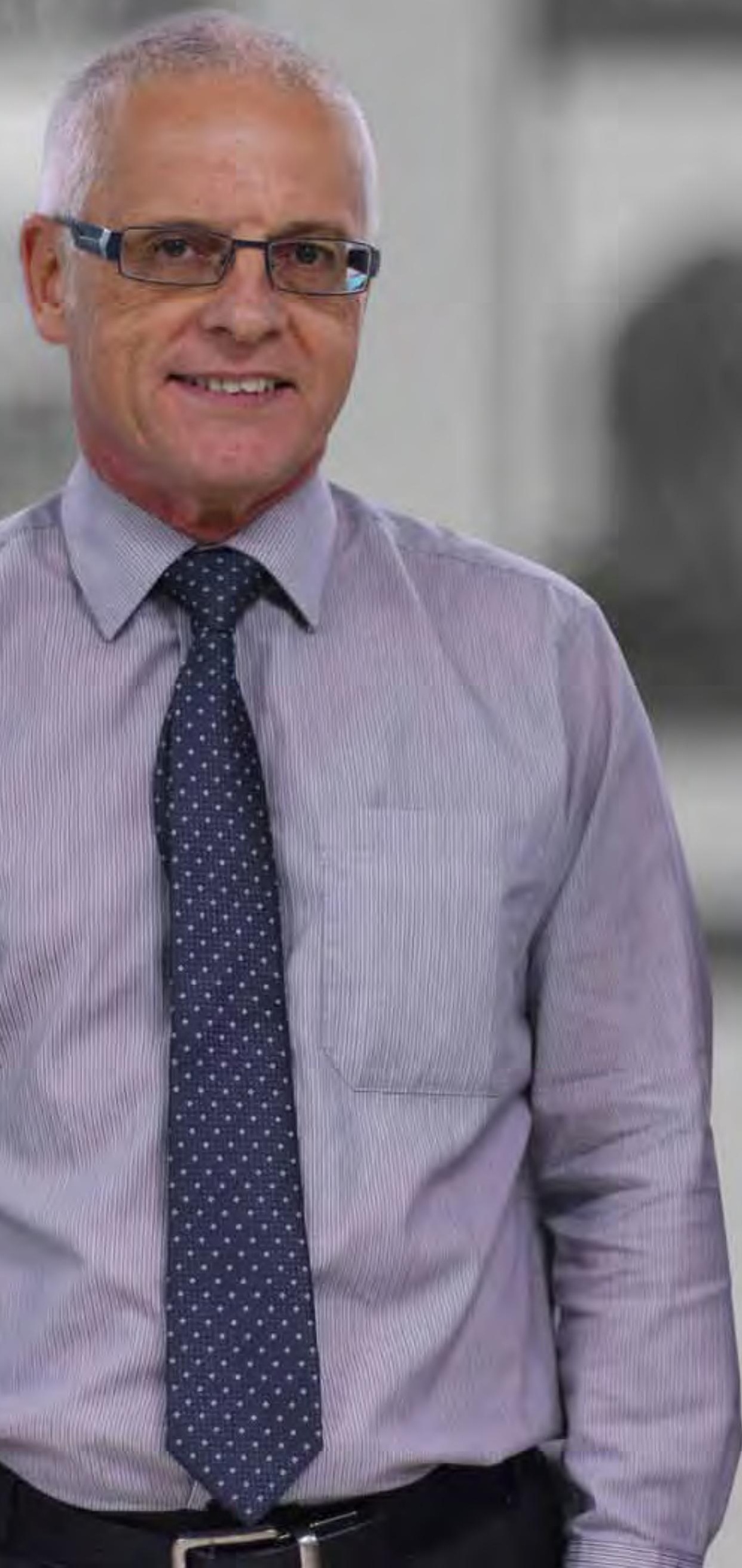


66 By contrast, for example, when New Zealand introduced its world-renowned and relatively simple GST into a sophisticated business environment, which already maintained extensive business records, a period of 10 months between the passage of the empowering legislation and its commencement was allowed to facilitate a thorough taxpayer awareness programme, to train tax administration staff, and to permit the necessary changes to recordkeeping and IT systems. 99 


\section{STANDARDIZATION OF LEASE RENTS CHARGED TO RESORTS}

Up until December 2010, each resort paid island lease rents to the government (via the Ministry of Tourism) according to the terms of the lease agreement it entered into with the government for the use of the island. ${ }^{8}$ The amount was negotiated on a lease-bylease basis, based on the resort's bed capacity. Thus, the government had been receiving various amountsfrom $\$ 800$ to $\$ 45,000$ per bed each year ${ }^{9}-$ generating total annual revenue of approximately $\$ 109.5$ million by 2007.

One consequence of this arrangement was that a large resort on a small island could pay far more land lease rental than a small high-end luxury resort with few rooms located on a large island. The extant lease rent regime was therefore criticized by the tourism industry as inequitable and a disincentive to increase the capacity of resorts and to promote their expansion, thereby limiting their future revenue potential.

An amendment to the Tourism Act in September $2010^{10}$ changed the basis of calculation of the lease rents applicable to all resorts to one based on the area of a resort island. The new formula incorporated a graduated scale, shown in Table 2.

Table 2: Tourist Resort Lease Rent Scale

$\begin{array}{lll}\text { Land Area } & \text { Rent Payable } & \text { Maximum Rent Payable } \\ \begin{array}{lll}\text { (a) }<200,000 \mathrm{~m}^{2} & \$ 8 \text { per sq. metre } & \$ 1,000,000 \\ \text { (b) } 200,001-400,000 \mathrm{~m}^{2} & \$ 1,500,000 & - \\ \text { (c) }>400,000 \mathrm{~m}^{2} & \$ 2,000,000 & -\end{array}\end{array}$

Source: Author.

Section 6(e) of the Tourism Act (Law Number 2/99).

Although, by September 2010, the highest amount was $\$ 11,727$ per bed per year.

10 Section 3 of the Second Amendment to the Tourism Act (Law Number 20/2010), which took effect on 8 September 2010. The wording of that section is confusing. Table 2 depicts how the section applies to lease rental payments in practice. The amendment Act also provided for extensions of lease periods for up to 50 years, upon payment of a lease extension fee of $\$ 100,000$ for each year of extension. Lease extension fees were required to be paid in full in quarterly installments within 24 months from 6 February 2014; otherwise, the extension of the lease would be invalidated (sections 1 and 2 of the Fourth Amendment to the Tourism Act [Law Number 4/2014]). A lease period may be extended to 99 years where: (a) the lessee is a public company registered in Maldives and leases the land for development of a tourist resort (which is one of the objects stated in the company's Memorandum of Association) (section 5 of the Second Amendment to the Tourism Act); or (b) a developed resort has been opened, all amounts owing to the government have been paid, and a lease extension fee of $\$ 5,000,000$ has been paid (section 2 of the Seventh Amendment to the Tourism Act [Law Number 8/2015]). 


\section{Lessons}

1. Adopt a realistic establishment period for the introduction of new taxes

2. Coordinate with the Central Bank in advance of the introduction of indirect taxes to ensure that there are sufficient notes and coins of the right denomination in circulation to meet the requirement for businesses to give the correct change in transactions with their customers

3. Review the legislation to identify areas that need to be supplemented by regulations 


\section{SPECIAL ECONOMIC ZONES}

On 27 August 2014, Parliament passed the Special Economic Zones (SEZ) Act, ${ }_{11}^{1}$ which was ratified by the President on 1 September 2014. ${ }^{12}$ This Act offers approved investors and developers in newly created SEZs a wide range of generous exemptions from customs duty, BPT, GST, and WHT for periods ranging from 2, 5, or 10 years (and, in some cases, indefinitely), depending on the nature and circumstances of the investment. Its provisions override those in any of the taxing acts. It remains to be seen how implementation and the resultant effects of this legislation pan out.

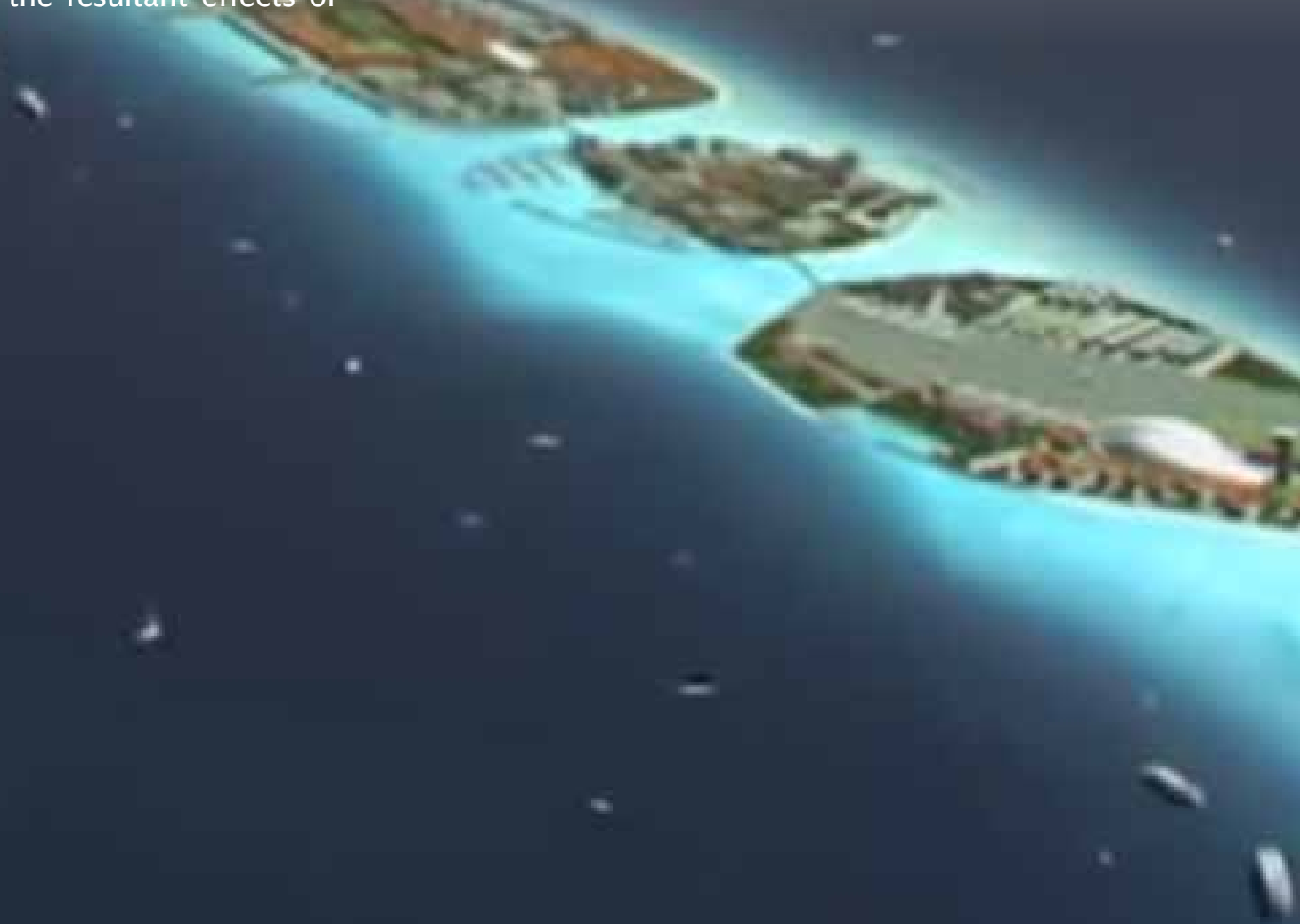

8

1 Law Number 24/2014.

12 The Act provides that some sections took effect on 1 September 2014 and other sections on dates proclaimed by the President. In any event, all of its provisions came into effect by 1 January 2015 (section 7 of the SEZ Act). 


\section{1 personally support the tax system. It helps provide basic needs of the country. Overall, the tax reforms have been a good thing. 99}

Abdulla Thayyib Managing Director, Aquaventure Maldives

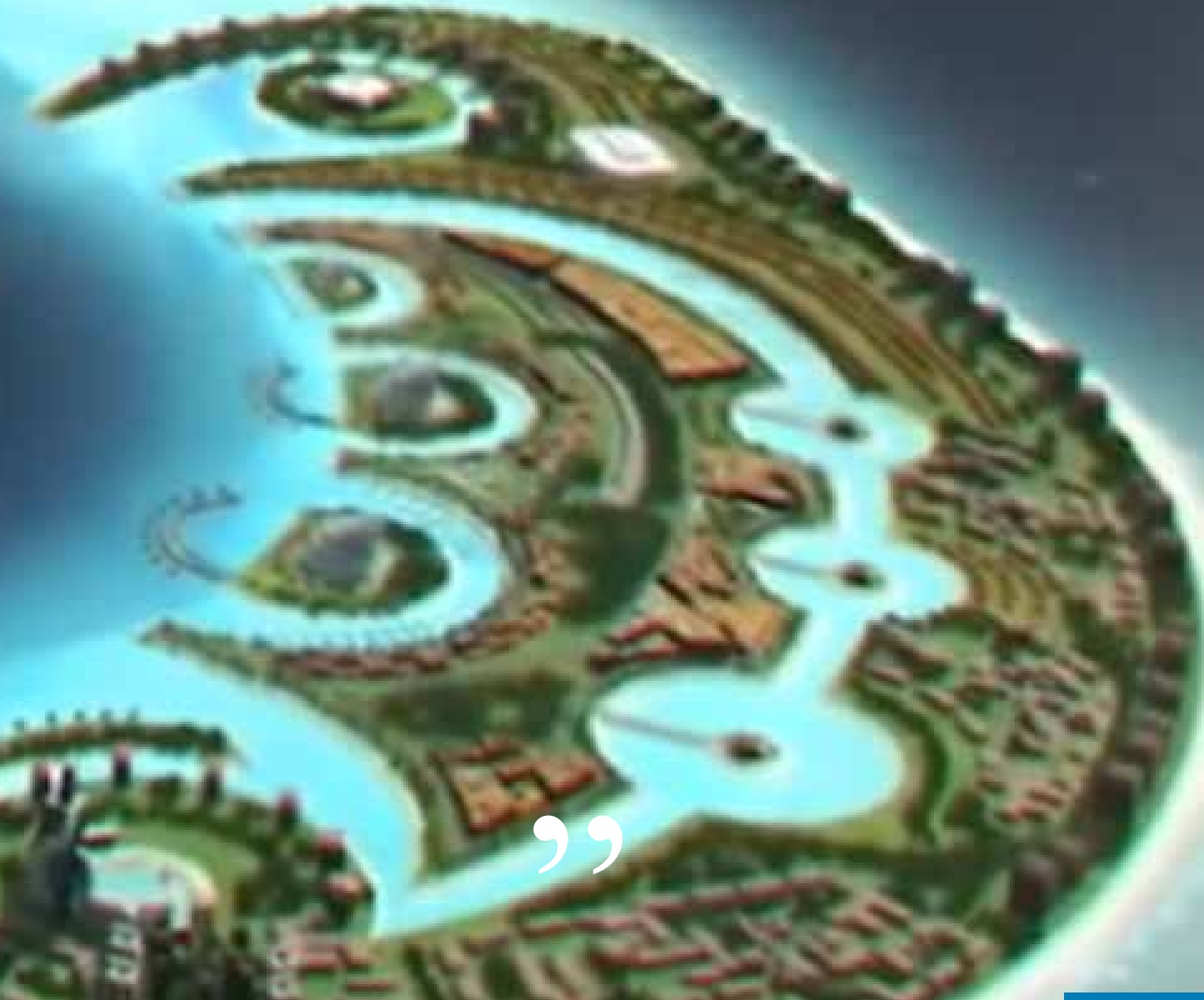


CHAPTER 4

Establishment of the

Tax Administration

System 
ris

है
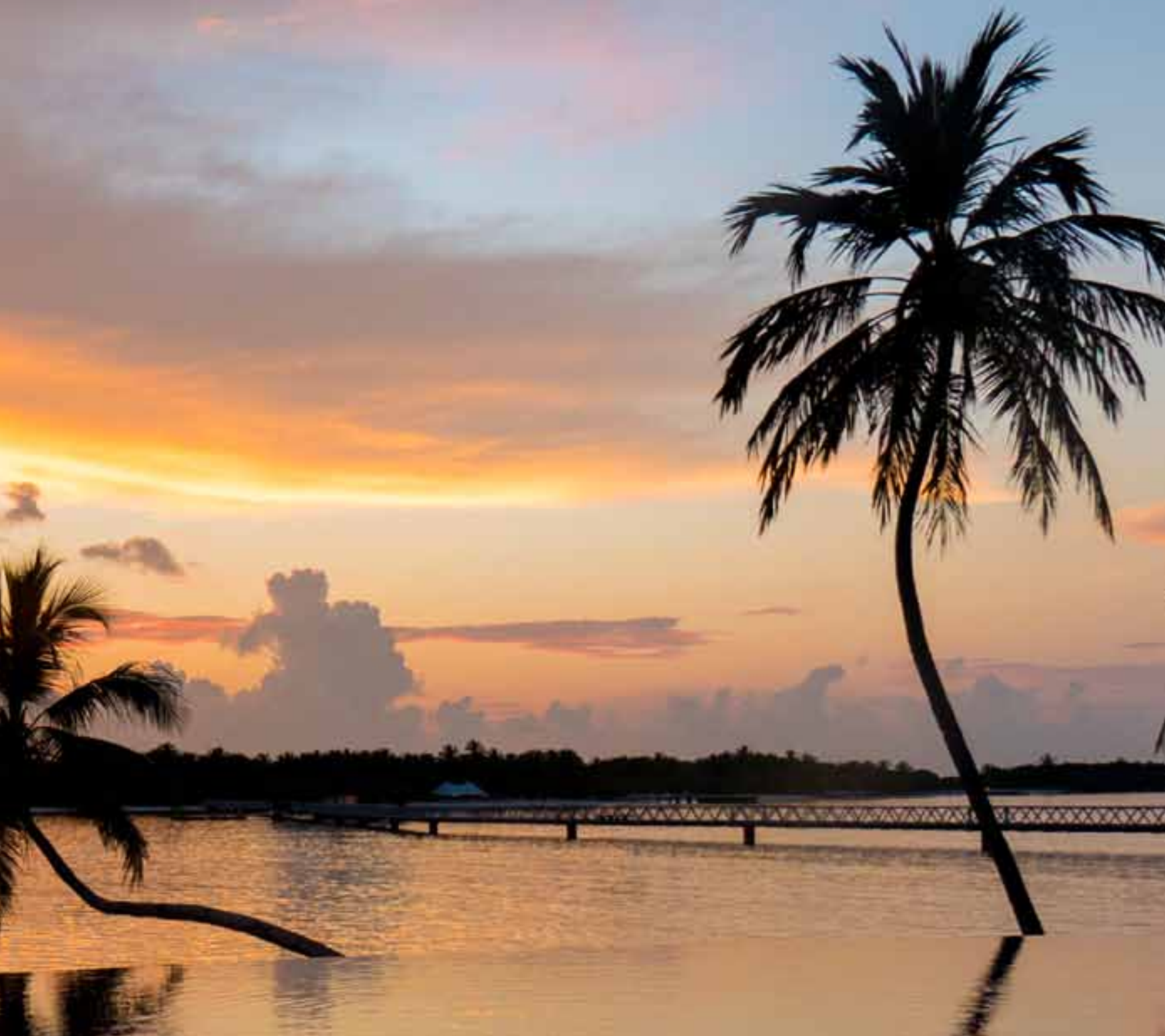

4 


\section{INCEPTION OF MALDIVES INLAND REVENUE AUTHORITY}

The necessary first step to implementing a new tax system is to put in place the legislation that provides the framework for the operation of the new regime. That was done on 18 March 2010 by way of the President's ratification of the Tax Administration Act (TAA). ${ }^{1}$

As we saw in Chapter 2, the Department of Inland Revenue (DIR) was established in 1996 as a division of the Ministry of Finance and Treasury (MoFT). Although it was a largely an autonomous unit within MoFT, DIR was nevertheless responsible to, and under the control of, the Minister of Finance and Treasury. That direct government control of the administration of taxation in Maldives was severed when Maldives Inland Revenue Authority (MIRA) was established as a "separate and independent legal entity" under section 2 of the TAA. The purpose of that separation was to ensure confidentiality of taxpayer data and to facilitate public confidence in the tax administration.

Section 3 of the TAA lays out the main aims of MIRA, viz. to: (a) enforce the tax laws and implement tax policies;

(b) carry out all work in respect of collecting all taxes imposed by the State pursuant to the law;

(c) ascertain whether the amount of tax payable has been calculated in accordance with the laws and regulations by all taxpayers and that any tax, fees or other monies payable are paid in full as and when they fall due;

(d) have regard for the rights of taxpayers whilst exercising the authority of MIRA;

(e) give full information to taxpayers on the tax laws and regulations, and make efforts to minimize the costs involved for taxpayers in paying taxes;

(f) plan a system, whereby the costs of administering tax will be minimized;

(g) prescribe the content and prepare tax returns, claims, statements, notices and other such forms required under the tax laws and make any amendments, if required; and

(h) establish a convenient mechanism for the administration of tax by means of modern technology.

\footnotetext{
Law Number 3/2010.
} 


\section{Box 5: Maldives Inland Revenue Authority's Vision Statement}

"To be recognised as a leading professional organisation engaged in collection of revenue in an effective and efficient manner and providing high-quality service to taxpayers."

The Tax Administration Act (TAA) also established a Board of Directors, the purpose and functions of which are to: ${ }^{\text {- }}$

1. Formulate regulations required to be made pursuant to the tax laws and determine procedures to be adhered to by taxpayers in order to assist them comply with the law;

2. Review the assets of the Commissioner General of Taxation and employees of Maldives Inland Revenue Authority (MIRA) and make regulations required for such review;

3. Ensure that MIRA makes efforts to implement the tax policies determined by the Minister, and advise the Minister on the changes required to achieve the objectives of MIRA; and

4. Advise the Commissioner General of Taxation on the administration of MIRA, where required.

a Section 4 of the TAA.

Source: MIRA. 


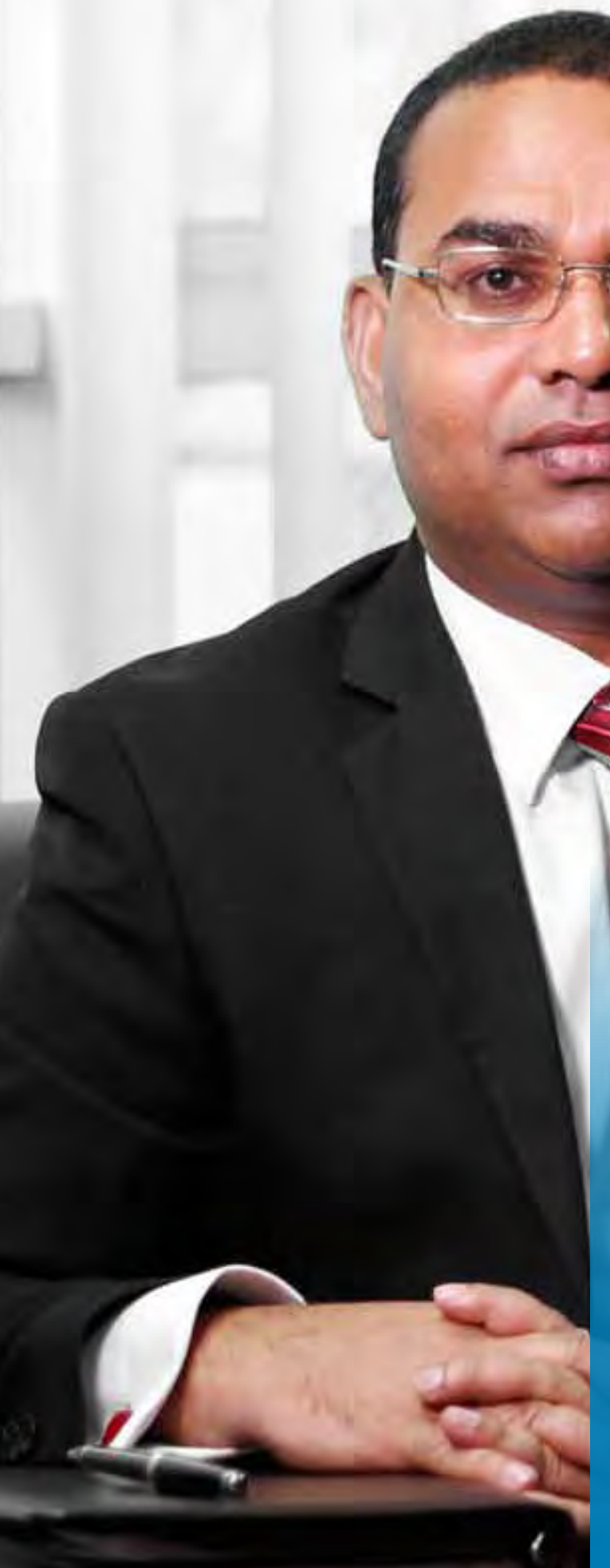

66 The Board of Directors is there to give guidance. It makes management more responsible. They are a check on corporate governancea watchdog. 99

Yazeed Mohamed Commissioner General of Taxation 


\section{RELATIONSHIP BETWEEN MALDIVES INLAND REVENUE AU- THORITY AND THE GOVERNMENT}

One shortcoming of the TAA is that it does not specifically set out the relationship between MIRA and the government (via the Minister of Finance and Treasury). As section 3(a) and (b) of the TAA makes clear, MIRA's role is, amongst other things, to "enforce the tax laws and implement tax policies" and to "carry out all work in respect of collecting all taxes imposed by the State." It is the role of the government to make tax policy. Yet the legislation is silent about the link between the Minister of Finance and Treasury and MIRA to convey tax policy from the former to the latter, and the information flow (within the bounds of taxpayer confidentiality) from the latter to the former, to inform the government's tax policymaking efforts. Although the Board is instructed to "ensure that the
MIRA makes efforts to implement the tax policies determined by the Minister, and advise the Minister on the changes required to achieve the objectives of the MIRA," there is no statutory mechanism by which the Minister is advised "from the ground up" on changes required to achieve the government's tax policy objectives. That is left to be achieved on an informal basis.

Ideally, tax administration legislation should prescribe a formal integrated circular flow of information and policy objectives between the government and MIRA, along the lines illustrated in Figure 8.

\section{Flgure 8: Information Flows Between Government and Tax Administration}

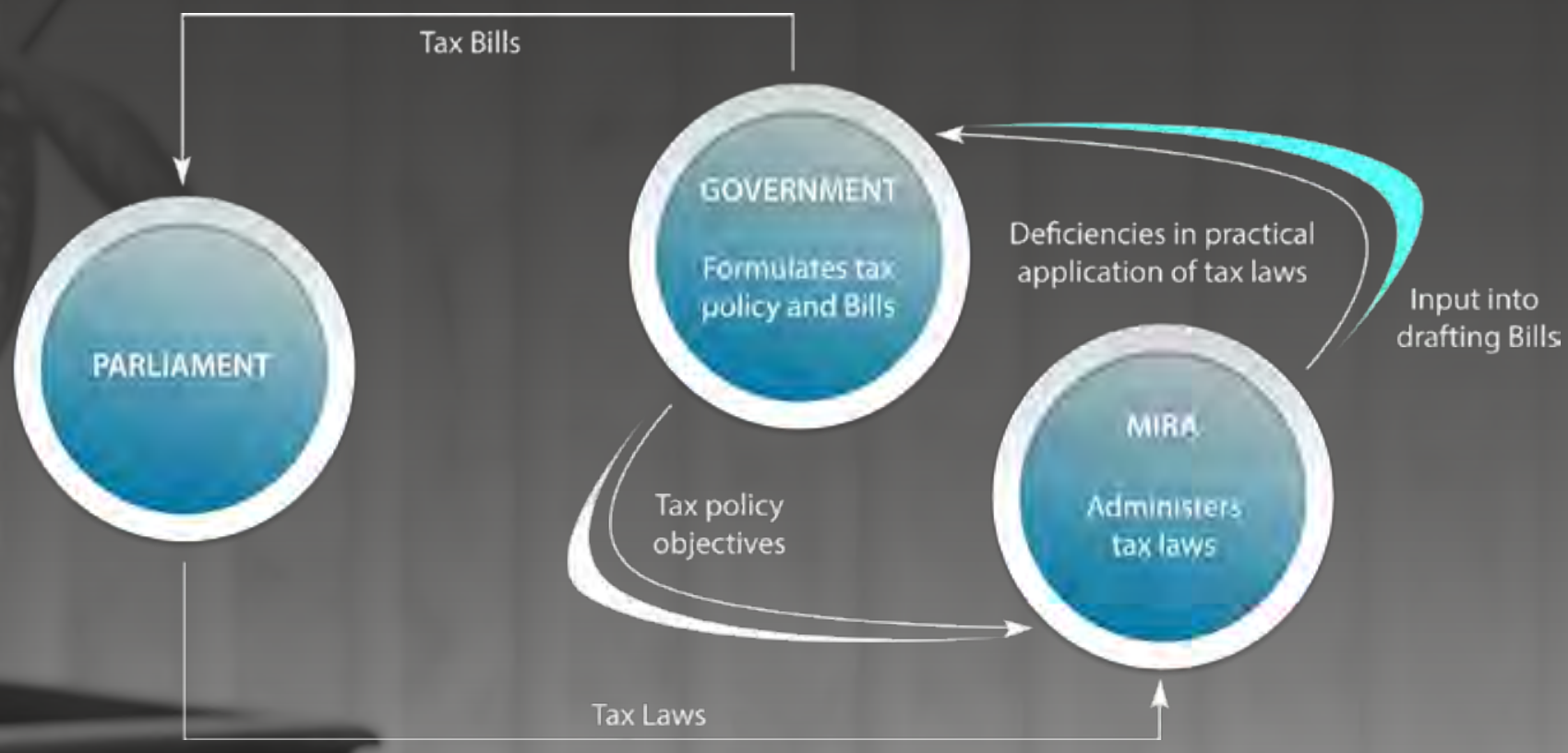

MIRA = Maldives Inland Revenue Authority.

Source: Author. 



\section{MIRA has no influences from MoFT.}

It is right for MIRA to implement its own policies and procedures, and give better incentives to technical staff and train them. This helps to retain them. MIRA's independence also ensured that taxpayer data was kept confidential, which increased taxpayers' trust in MIRA. But the disadvantage is that when we need financial assistance, MIRA does not have a direct voice in Cabinet. There is a detachment from government when resources are being allocated. However, we appreciate the assistance we have been receiving by Finance Ministers in catering for our financial requirements in most cases. 99

Hassan Zareer 


\section{ORGANIZATIONAL STRUCTURE}

MIRA is headed by the Commissioner General of Taxation who, together with the Deputy Commissioner General, is appointed by the President of Maldives with the approval of Parliament, in accordance with section 8 of the TAA. The Commissioner General is required to carry out the functions prescribed in the TAA and other tax laws, and to oversee the day-today administration of MIRA. ${ }^{3}$

Where required, the Commissioner General is advised by MIRA's Board of Directors on the administration of MIRA. The Board of Directors comprises seven members (including the Commissioner General and the Deputy Commissioner General of Taxation) who are also appointed by the President, with the approval of Parliament. The Board itself appoints its Chairperson and Deputy Chairperson.
The Commissioner General and Deputy Commissioner General are supported by a senior management team made up of five Directors General (Director GeneralAudit and Investigation; Director General-Enforcement and Compliance'; Director General-Technical and Public Awareness; Director General-Return and Payment Processing; and Director General-Human Resources and Administration) and eight Directors (Senior DirectorLarge Taxpayer Service; Senior Director-Enforcement; Director-Technical Service and Planning; DirectorHuman Resources and Administration; Director-Internal Audit; Director-Legal Affairs; Director-Investigation and Intelligence; and Director-Audit and Assessment).

After some restructuring as its organizational experience developed, MIRA had nine divisional units in 2015. They comprised seven "front line" units (1-7 in Figure 9) and two "back office" units (8 and 9).

\section{Figure 9: Organizational Structure of Maldives Inland Revenue Authority}

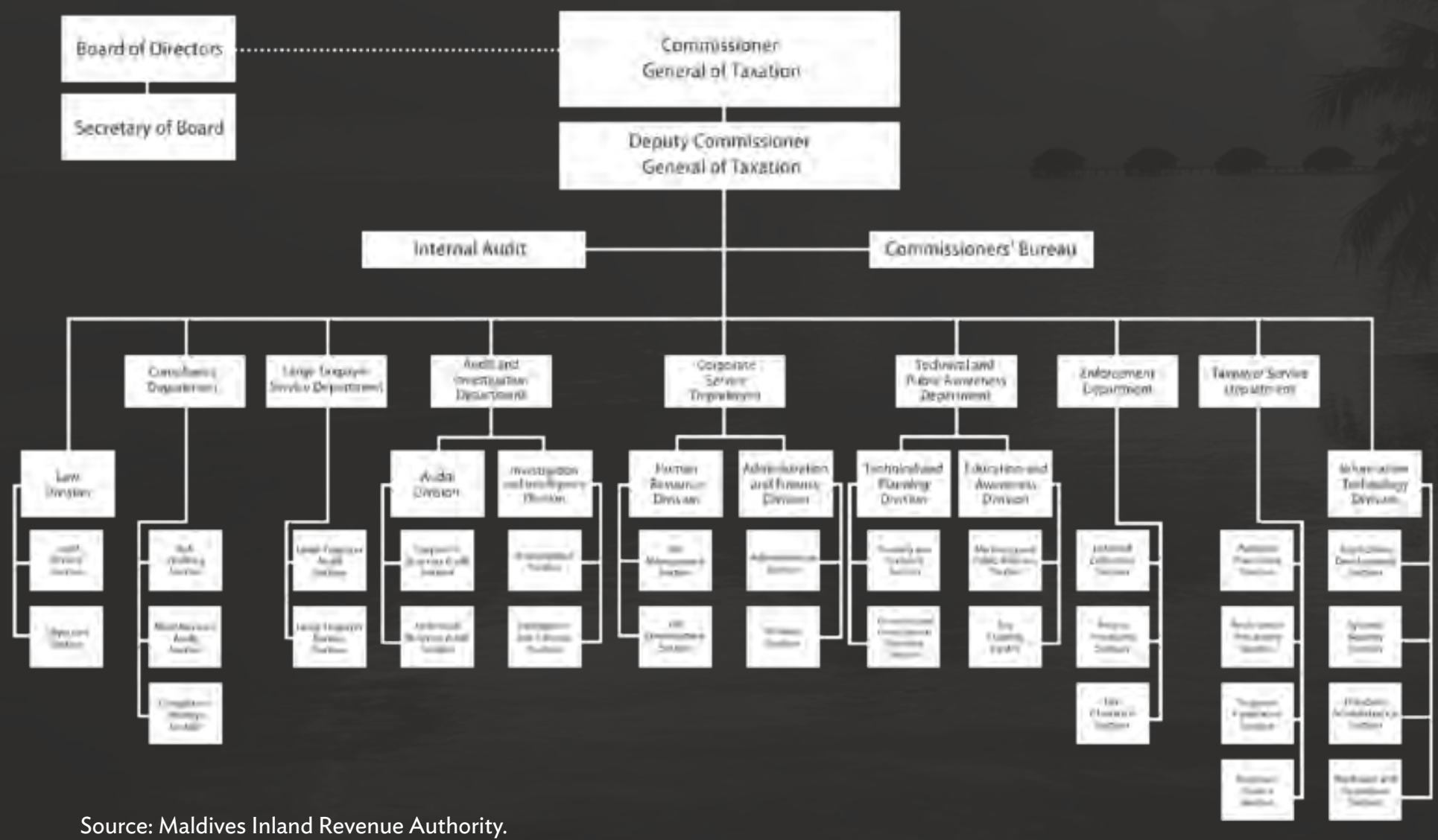

3 Section 10 of the TAA. 
The functions of each division are:

1. Commissioners' Bureau

- Manage Commissioners' offices

- Review taxpayer objections

- Represent MIRA in the Tax Appeal Tribunal and courts

- Undertake all other legal work

- Internal audit

2. Compliance Department

- Conduct microbusiness audits

- Compile taxpayer risk profiles

- Implement compliance strategy

3. Large Taxpayer Service Department

- Deal with large taxpayers, i.e., taxpayers which meet certain criteria related to size and ownership

- Verify whether large taxpayers are correctly calculating their tax in accordance with the tax laws and regulations, by conducting Goods and Services Tax (GST), BPT, Withholding Tax (WHT) and bank profit tax audits

- Ensure that large taxpayers file returns and make tax and other payments on time

- Provide assistance to, and resolve tax issues with, large taxpayers

4. Audit and Investigation Department

- Verify whether all taxable companies and individuals are correctly calculating their tax in accordance with the tax laws and regulations through:

» GST audit

» BPT audit

» WHT audit

» Tourism tax audit

» Green tax audit
- Conducting investigations

- Gathering intelligence

- Undertaking forensic activities

- Issuing assessments to nonfilers

5. Corporate Service Department

- Manage administrative procedures

- Human resource management

- Staff training

- Budget and financial statements

6. Technical and Public Awareness Department

- Prepare technical advice to government for the formulation of tax policies

- Plan and implement tasks necessary to implement tax policy

- Compile tax regulations and rulings

- Maintain and analyze revenue statistics

- Establish and maintain relations with other tax administrations and international tax organizations

- Educate taxpayers by providing comprehensive information to them

- Organize and conduct tax training programs through MIRA's Tax Training Academy

- Conduct tax awareness programs

- Marketing and public relations

7. Enforcement Department

- Process tax returns

- Undertake all necessary actions to recover taxes and other amounts collectible by MIRA from persons in default

- Take action against persons that fail to file returns

- Issue tax clearances 
8. Taxpayer Service Department

- Identify and register persons required to register under the tax laws

- Receive tax returns

- Receive and process tax payments

- Taxpayer facilitation, i.e. responding to taxpayer queries

- Monitor the work of regional branches
9. Management Information Systems Department

- Information communication technology

- System security and maintenance

- System hardware

- Developing software applications

- Database management and maintenance

\section{Box 6: Maldives Inland Revenue Authority's Mission Statement}

"To establish a highly committed and competent organisation, delivering effective and fair administration of the tax laws, promoting voluntary compliance and providing quality services to taxpayers."

Source: Maldives Inland Revenue Authority.

\section{INTERNAL COMMITTEES}

MIRA has established a number of committees in relation to particular areas of its work, which advise the Commissioner General. In 2015, there were 13 such committees:

1. Policy Committee

2. Technical Committee

3. Audit Committee

4. Appeal and Objection Committee

5. Human Resources Committee

6. Bid Evaluation Committee
7. Fine Relief Committee

8. Steering Committee for the disclosure of GST registered persons in default

9. Award Committee

10. Sexual Offenses Prevention Committee

11. Review Committee under the Right of Information Act

12. Licensing Committee

13. Technical Support to Legal Team Committee 


\section{STAFF COMPLEMENT}

Ultimately any organization is only as good as the staff which it employs. MIRA is no exception. To attain its values and to carry out its mission, MIRA has successfully recruited skilled staff, including many accounting, business, and law graduates.

The focus of MIRA's staff recruitment strategy is to employ young and motivated people who are enthusiastic about achieving MIRA's objectives, and to train and to instill a work commitment in them.
Generally, MIRA staff are not recruited from other government agencies. As a body independent from the Maldives public sector, MIRA has, to a large extent, been free to reward its employees for performance, unfettered by remuneration constraints imposed on government departments.

As an anti-corruption measure, a subcommittee of the Board of Directors periodically reviews the assets and liabilities of all MIRA employees.

\section{The staffing policy has been to recruit bright, young people who have a committed work ethic. While we recruit the cream of young qualified people, we cannot retain all of them.}

\section{Industrious staff of MIRA have established themselves as exemplary by working tremendously hard in achieving the objectives of MIRA and continue to build MIRA as a proficient tax authority with integrity and fairness. 99}

Yazeed Mohamed

Commissioner General of Taxation 


\section{INTERNAL ADMINISTRATIVE PROCEDURES}

Following best business practice, MIRA has developed and documented internal procedures for its administration functions. These cover the administration of MIRA's key resource: its staff. MIRA's internal Staff Administration Regulation addresses:

- Organizational structure

- Confidentiality

- Staff indemnity

- Code of conduct

- Disclosure of personal information

- Declaration of assets and liabilities

- Commissioner General
- Deputy Commissioner General

- Committees

- Recordkeeping

- Recruitment

- Working hours

- Corrective actions

- Termination of employment

- Salaries and bonuses

- Leave

- Evaluation

- Training

- Promotion

\section{Box 7: Maldives Inland Revenue Authority's Logo}

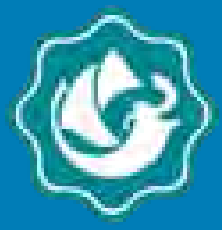

The shape of the logo of Maldives Inland Revenue Authority (MIRA) is derived from Maldives' 5 laari coin, which represents the national revenue, while the vessel within it signifies the traditional Vaaru Odi (sailing vessel) used to collect Vaaru, a form of tax. The points of the octagonal shape indicate MIRA's reach to all corners of Maldives, while encompassing an Islamic theme.

The conch portrayed in the hull of the vessel conveys a call for voluntary compliance, the conch being a conventional medium to call the community for participation in national matters.

The turquoise colour of the logo resembles the shallow waters of Maldives' lagoons, which reflect fairness and transparency that MIRA embodies in reaching its objectives. 
MIRA has given high priority to staff development and training both to enhance the staff's technical skills and personal and career development, and to keep staff motivated. Given the new staff's lack of experience in taxation matters, and to quickly develop their technical knowledge, the initial training focus centered on tax laws and procedures.

Employees participate in both local and overseas training programs, and conferences and seminars, and receive study awards to obtain Association of Chartered Certified Accountants (ACCA) qualifications. To enhance their knowledge, all new recruits participate in a formally structured induction program.

A training unit was established to provide regular training to taxpayers and to develop on-going staff training. Training programme syllabi were developed.

Staff training takes the form of:

- technical workshops on tax policy, tax laws and international tax;
- general support training delivered by dedicated institutions (e.g., on International Financial Reporting Standards and accounting issues, Islamic finance, Dhivehi language, audit forensics, corruption prevention and stress management);

- informal on-the-job support training

- "Train the trainers" training programmes (particularly for licensed tax agent (LTA) training); and

- overseas training with participants from other tax administrations.

In 2012 and 2013, training on tax laws and regulations, and MIRA's policies and procedures was extended to members and staff of the Tax Appeal Tribunal (TAT) and the judiciary.

To create a smooth working relationship between MIRA and TAT, discussions at a technical level were undertaken to rectify issues with documents and information exchanged by both institutions.

\section{Numerous changes and works have been carried [out] to make the administration a "customer-oriented" place, rather than the "employee-oriented" place often seen in many State institutions. Works have been carried out to make MIRA a learning organization which understands the emerging issues in taxation and is aware of the changes in the global business environment. 99}

Yazeed Mohamed 
ON-THE-JOB TRAINING BY EXTERNAL CONSULTANTS

MIRA found that one of the most effective forms of external technical assistance is on-the-job training provided by international consultants. This involves an extended presence of the consultants within
MIRA, working with staff in the office and in the field. The consultants are available on call to assist in legal interpretation matters, to advise on how to deal with taxpayers, and to provide guidance in field audits.

66 Much of the external consultant's work under a longterm presence, on-the-job training arrangement in a nascent tax administration is to build up the confidence of inexperienced staff to deal with taxpayers and their technical issues. A strong rapport is established with the staff. The advantage of this approach is evident, for instance, in taxpayer meetings, to neutralize the power imbalance between young and unsophisticated third world developing country tax administration staff and first world MNE corporate head office "heavyweights" and their professional advisors; and in field audits, where a taxpayer can be recalcitrant and sometimes aggressive. 99

Kevin Holmes ADB International Tax Adviser to Maldives (2011-2015) 


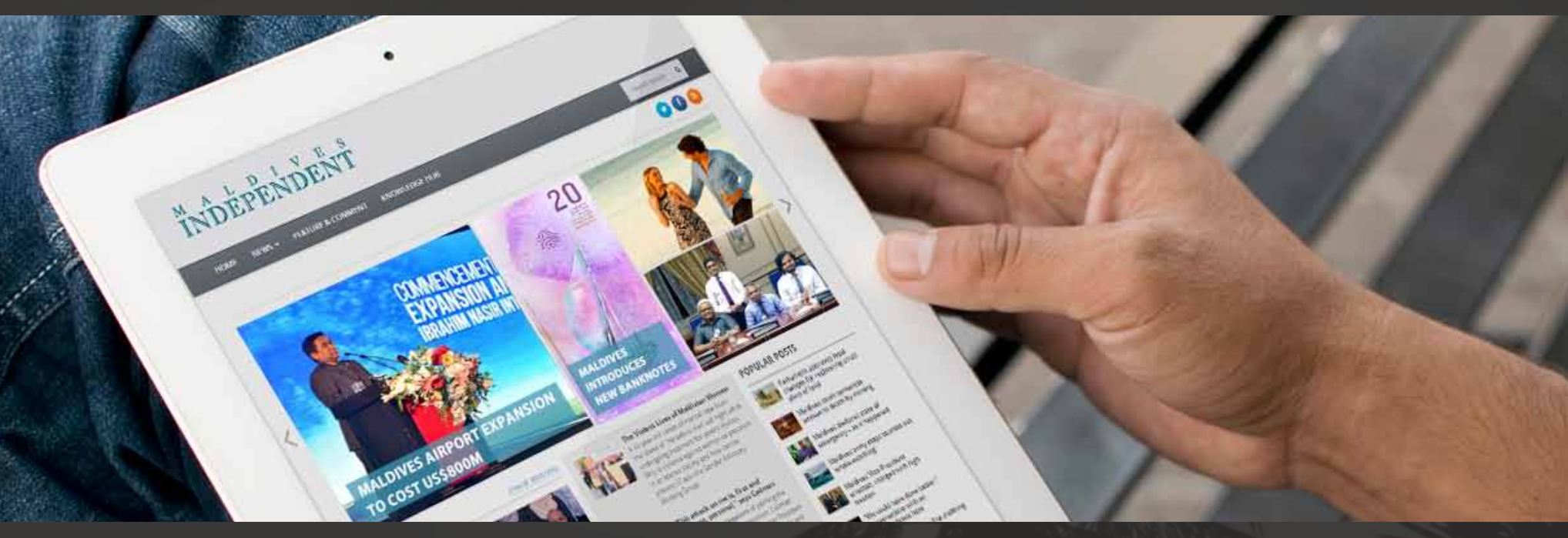

66 There are those rare projects which were heavily supervised and set up with the help of foreign technical expertise such as the Pension Fund and MIRA which can boast a fair level of success ...99

Reader comment Maldives Independent, 13 May 2015

\section{Lessons}

1. Establish an independent revenue authority governed by its own statute.

2. Formalize information flows between the government policymakers and the tax authority, and vice versa.

3. Formulate a comprehensive organizational structure with clear lines of authority and responsibilities.

4. Recruit young qualified staff, committed to the organization's objectives, and untainted by undesirable past work practices.

5. Subject all staff to periodic anti-corruption reviews.

6. Reward staff for performance.

7. Invest heavily in staff training at technical, career development, and personal levels.

8. Engage appropriately qualified and experienced external consultants to work alongside staff to give advice and on-the-job training. 

66 MIRA has become the primary center of revenue for the Maldivian government. It has become an admired institution among everyone. 99

Ahmed Mohamed Chairman of MIRA Board of Directors (2010-2015) 


\section{REGISTRATION OF TAXPAYERS}

From 1 October 2010, MIRA began to establish a register of all taxpayers that pay taxes and government fees and duties, which were to be collected by it. As payers of the first tax, Tourism Goods and Services Tax (T-GST) taxpayers were the top priority for registration.

Application of the T-GST was confined to supplies of goods and services in the Maldives tourism sector. Because of the limited number of taxpayers which were required to account for T-GST, most potential taxpayers were registered from the commencement of the regime. The Ministry of Economic Development's (MED) database of operators in the tourism sector was used as a benchmark to ensure that all liable T-GST taxpayers were brought within the tax's net. The initial list of registered taxpayers was then buttressed by surveillance procedures designed to capture existing potential taxpayers and to monitor new taxpayers, which were subject to general business registration. MIRA also adopted monitoring procedures using other data captured by it (e.g., fees, royalties, etc. collected by MIRA).

The T-GST database (being a subset of the register of all taxpayers) also became a reliable check on BPT taxpayers in the tourism sector, since that database was comprehensive insofar as resorts and other enterprises supplying goods and services to foreign tourists were concerned (e.g., dive centers, spas, shops and boutiques located at resorts), which are often outsourced by resorts. This is the most significant sector group contributing to BPT.

The MED also maintains a database of cooperative societies, trade permits for various business ventures, copyrights, import and export licences, and local and foreign investments. Where appropriate, MIRA examines these databases to identify potential taxpayers not already registered with MIRA.

The Registrar of Companies is required under section 20 of the TAA to notify MIRA of newly incorporated companies and foreign companies becoming registered in Maldives, within 2 months of the respective event. Again, where appropriate, MIRA checks the information in these updates with its own databases to identify potential taxpayers not already registered with MIRA, although generally MIRA already has this information since it is not possible to register a company until the relevant fee has been paid to MIRA. Furthermore, a tax or fee cannot be paid before a person is registered or has been issued a taxpayer identification number by MIRA.

The MED database captures, among other things, the nature, the accounting period, and the most recently filed accounting results of each registrant's business. Upon the introduction of the BPT regime on 18 July 2011, MIRA filtered this data into the following categories:

- Companies with pre-18 July 2011 balance dates,

- Companies with post-18 July 2011 balance dates,

- Individuals with pre-18 July 2011 balance dates,

- Individuals with post-18 July 2011 balance dates, and

- Registered businesses that are inactive.

This information was used to forecast 2011 BPT revenue and the timing of its receipt. 
The greatest exposure with Business Profit Tax registration concerns individuals who own rental properties and derive taxable rental income. The Male' City Council database of properties in Male' was examined, but it was not comprehensive. Teams of Maldives Inland Revenue Authority staff therefore physically surveyed all properties in Male' to determine the nature of occupancy (owned or tenanted), the owner of the property, the size of the property, etc., to enhance the robustness of the Business Profit Tax taxpayer database in respect of rental income.

Source: Author.

\section{TAXPAYER SERVICES}

Since the notion of paying tax was novel in Maldives, taxpayers required assistance to understand the new tax regimes and to comply with them. There were no tax consultants for taxpayers to turn to. Therefore, MIRA needed to quickly provide two key services to taxpayers: a taxpayer services unit and a public education programme.

On 1 January 2011, MIRA opened its Taxpayer Service Centre in Male', and a telephone hotline and dedicated website were subsequently launched in 2011 to provide basic information to taxpayers on taxation issues. Subsequently, regional taxpayer service centers were opened in Kulhudhuffushi (in the far north of the country) and Addu (in the far south of the country), and collection centers were opened in the Department of Immigration and Emigration office in Male' to facilitate the expedient collection of visa fees (Fuvahmulah, in the far south of the country; Fonadhoo, in the south of the country; and Nilandhoo and Eydhafushi, nearer to the center of the country. MIRA plans to open further service and collection centers in each atoll, to facilitate taxpayer compliance throughout the country.

MIRA also conducts taxpayer satisfaction surveys at its service centers.

\section{$\mathbf{6} 6$ In the outer islands and even the bigger atolls, there is non- compliance. By the end of 2016, we will open branches and have other presences in almost all 19 atolls. And we are going to address auditors and tax agents in the atolls. Currently, there are resource constraints with transport over the spread- out geographic regions, and with stipends. 99}

Yazeed Mohamed

Commissioner General of Taxation 


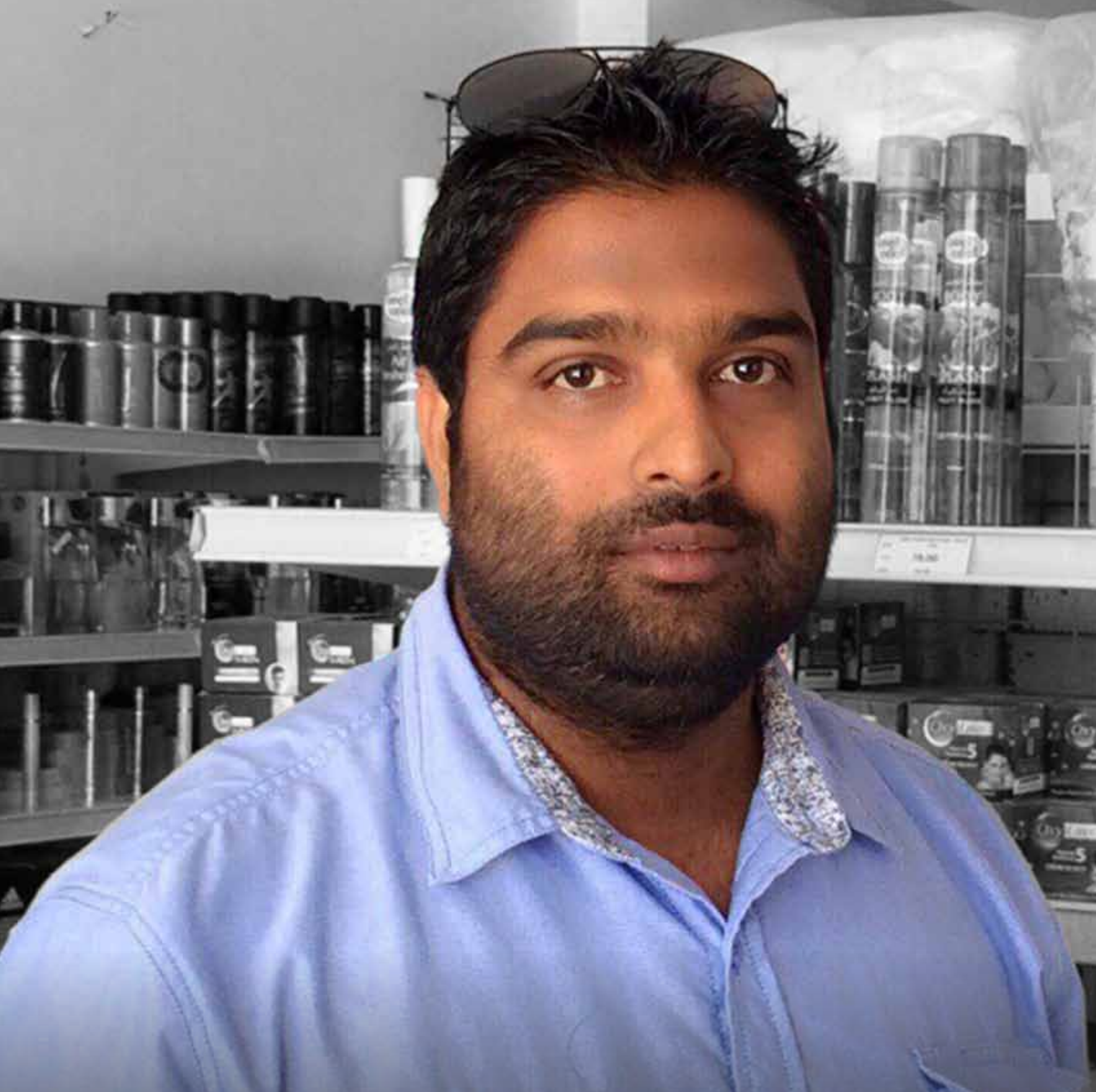

MIRAconnect was introduced in 2013, which allows taxpayers to register, update their information, and submit returns through the internet. On 11 May 2015, MIRA's online tax payment platform was launched.
As an additional measure to combat tax evasion, in 2013, MIRA incorporated into its website a "whistleblowing" platform, whereby anyone can anonymously share information about suspected tax offenses. 


\section{MIRA staff are very friendly and helpful. They give us all the information we need. It's easy to get answers with a phone conversation, and MIRA's internet webpage is easy to use and fast to get information from anywhere. 99}

Anwarusalam Aboobakuru Chief Operating Officer, Biyalanco, Kulhudhuffushi

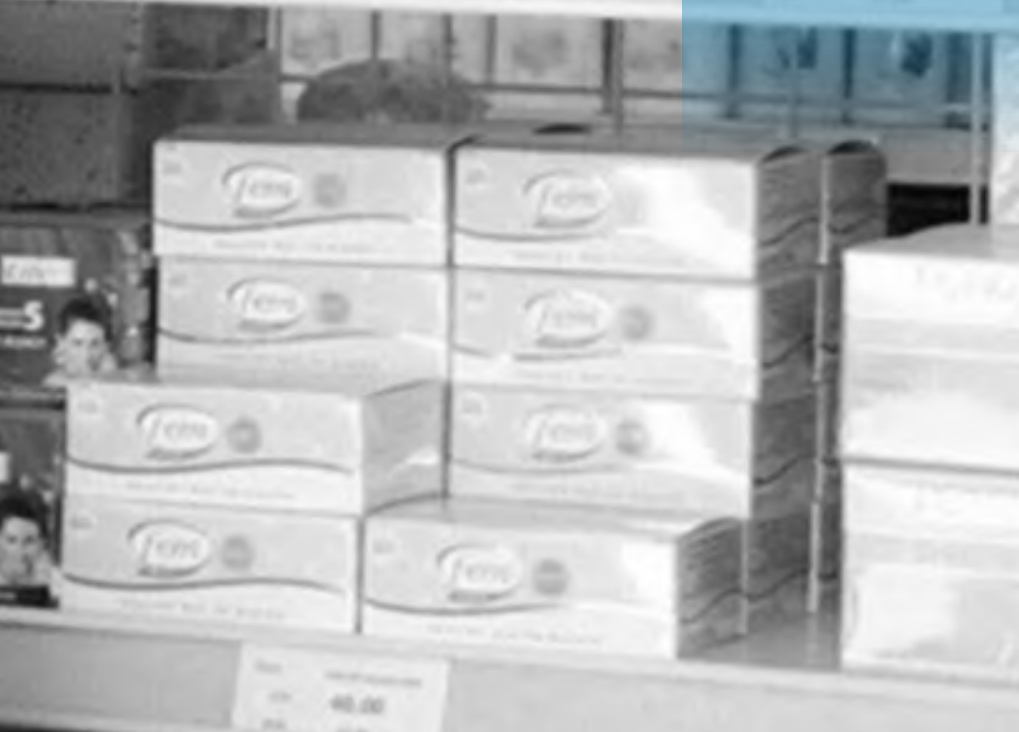




\section{$66_{\text {It is MIRA's belief that a positive }}$ outlook on MIRA from the} general public can be attributed to developing trust between MIRA and the public. Thus, different programs are conducted by MIRA in order to build relations and improve the view of the public towards MIRA. 99

MIRA Annual Report 2013

MIRA embarked on an extensive public awareness programme in 2011. With subsequent changes in the tax law and the increasing number of new taxpayers, the impetus of the public education mandate continues to be maintained, with the objective of cementing MIRA as the fountain of tax knowledge in Maldives.

\section{MIRA's public awareness}

campaigns have been effective in communicating with people. Maldives is a small community. It is easy to communicate messages. 99

Yazeed Mohamed Commissioner General of Taxation
Vitally, MIRA's public education programmes extend to schools. If it is to be successful in the long term, it is imperative that the concept and benefits of a modern tax system are embedded in the impressionable young minds of the nation's future taxpayers.

\section{All young people are on} social media. So communication on Facebook and the internet is the most effective way for MIRA to make young people aware of MIRA and the tax system.99

Fathmath Shaha Hassan Business Studies student, Clique College, Male' 
Public awareness activities in Male' and the atolls are delivered in both Dhivehi and English. These activities focus on BPT, GST and tax administration law and practice, regulations and rulings, and registration and tax return requirements. Taxpayer education activities include:

- Radio interviews

- Television interviews

- Television panel discussions

- Media releases

- News briefs to stakeholders

- MIRA website FAQs and examples for taxpayers

- Social media, e.g., use of Facebook and Twitter

- SMS messages to taxpayers

- Emails to taxpayers

- Flyers

- Brochures

- Banners

- Public billboards (both static and walking)

- Announcements in the Government Gazette

- Public seminars
- Public lectures

- Presentations to taxpayers and industry groups

- Presentations to accounting and consultancy firms

- Presentations to stakeholder government departments, including judges

- Workshops

- Television advertising, including on TV screens in cafes and restaurants

- Newspaper advertisements (in both traditional and online newspapers)

- Online tax awareness calendar

- Q\&A sessions

- School visits

- Circulars for public release

- 1415 MIRA hotline

- Road shows

- Attendance at fairs

Moreover, MIRA began producing its own television program, Vaaru (Tax) in 2012 and launched its first annual "tax week" in 2013. 


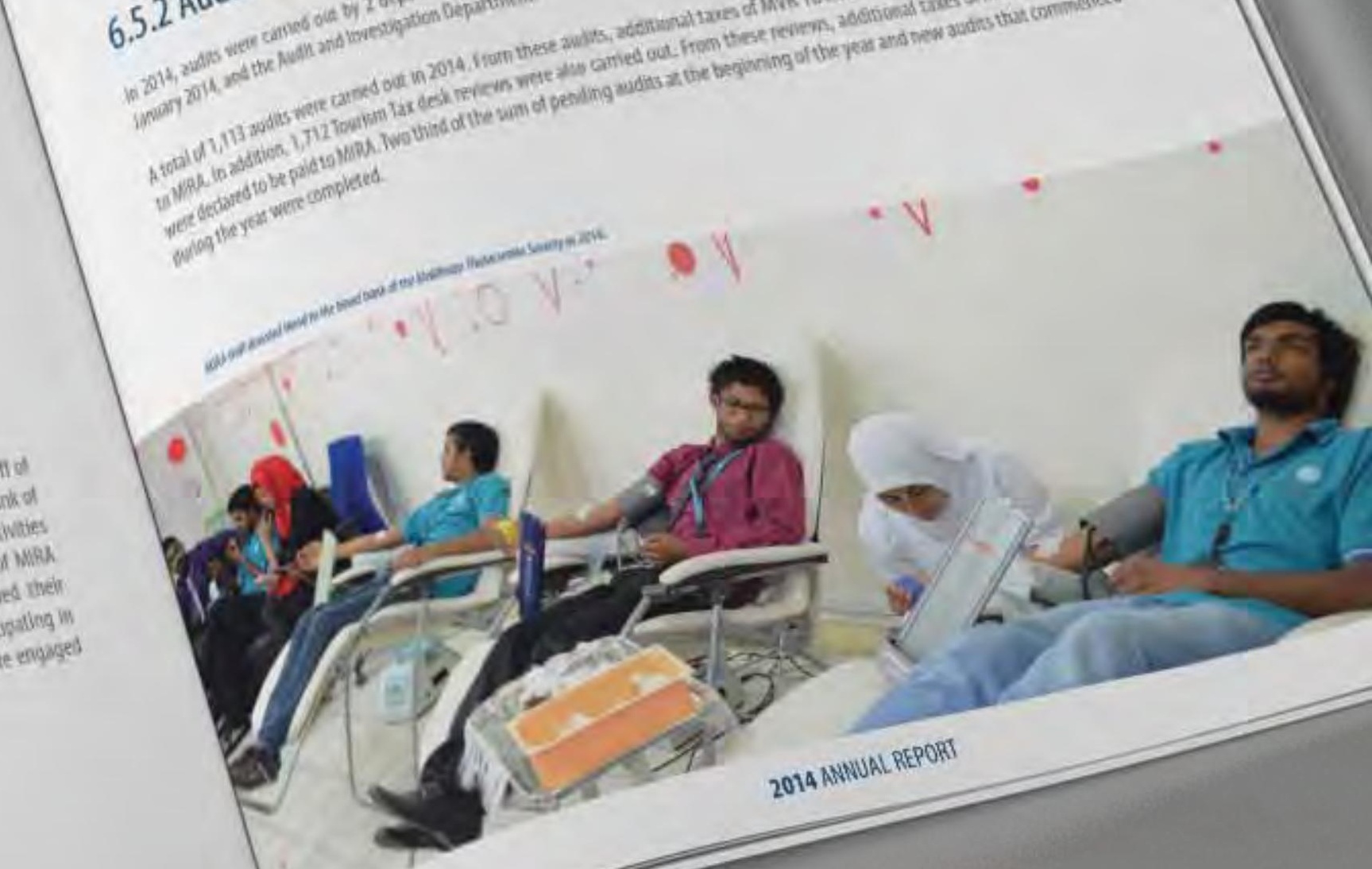

66 Educating and increasing awareness of taxpayers and the public on tax matters is considered to be a crucial component in encouraging taxpayers to comply with relevant laws and regulations. 99

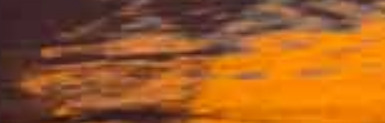




\section{RECORDKEEPING EDUCATION}

Because the Maldives economy is largely cash based, prior to the introduction of GST and BPT there was no imperative for businesses to maintain accounting records (other than companies registered under the Companies Act). But, of course, the effectiveness of self-assessment under the voluntary compliance GST and BPT regimes is critically dependent upon proper recordkeeping of transactions. The fledgling accounting profession in Maldives could not offer much help because it simply did not have the capacity to provide accounting services to the multitude of businesses that fell within the ambit of GST and BPT in 2011. It was therefore left to MIRA to educate small businessmen and landlords, in particular, about recordkeeping. MIRA developed and distributed templates of basic accounting records to allow taxpayers to record their transactions.

\section{Businesses were not keeping proper records. We had to}

start from scratch and provide them with books. Even large businesses - we had to encourage them and carry out enforcement actions to discipline them to keep proper business records. We are still struggling with this with small businesses, and have formed a separate department-a compliance team - to be in the field throughout the day to check that business records are being kept and proper tax invoices are being issued. This is leading to a culture of proper recordkeeping. 99

Hassan Zareer

Deputy Commissioner General of Taxation 


\section{TAXPAYERS' CHARTER}

A modern tax system is not about a tax administration unilaterally expropriating wealth from a country's citizens. Taxpayers have rights, which ensure that they are treated lawfully and fairly-and are not overtaxed-by the government. In this spirit, on 2 August 2014, MIRA published its Taxpayers' Charter, a statement of taxpayers' rights, obligations and responsibilities, and service standards that taxpayers can expect from MIRA.

With regard to taxpayers, per se, the Taxpayers' Charter sets out:

- taxpayers' rights to:

» be treated fairly and with respect;

» be treated as honest;

» receive professional service from MIRA;

» have reliable information and advice;

» have assistance to get things done correctly;

» easy compliance with tax requirements, have their information protected and their privacy respected;

» have their agents accepted by MIRA;

» have their right to complain respected;

» have their right to object to and appeal MIRA's decisions respected; and

» make MIRA accountable for its actions.

- taxpayers' obligations to:

» register with MIRA in accordance with the law,

» inform MIRA of any changes to the information that they have provided to MIRA,

» file returns and pay taxes in a timely manner,

» disclose relevant information and records,

» cooperate with MIRA staff,

» respect MIRA staff, and

» take care to ensure that their tax-related responsibilites are carried out correctly.

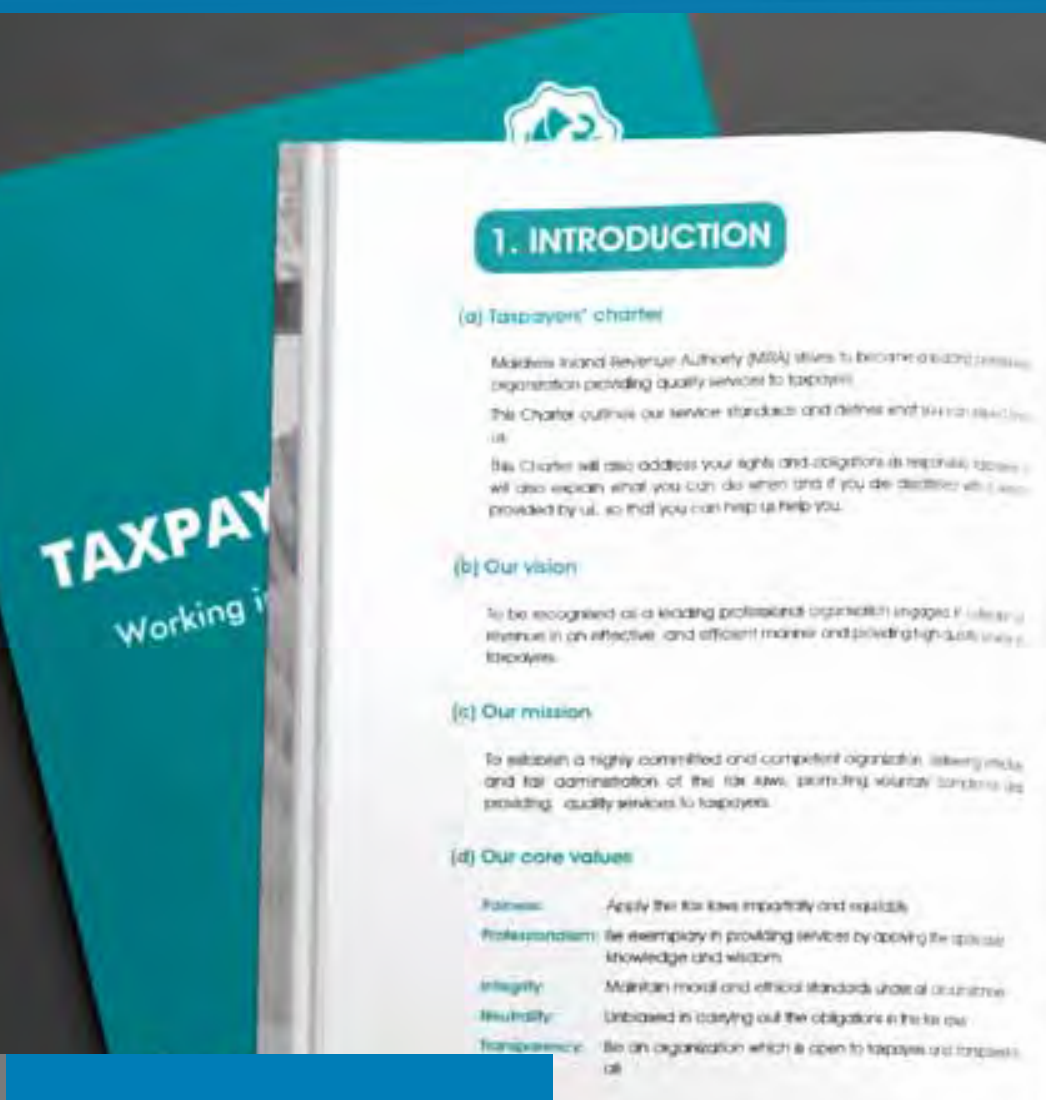

\section{YOUR RIEHTS}

You con expect us to

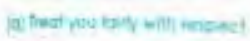

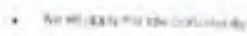

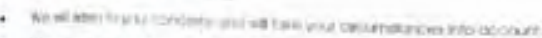

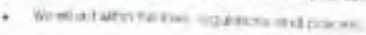

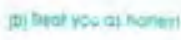

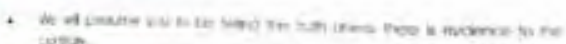
जotem

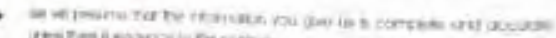

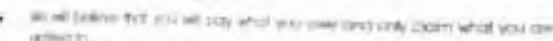
19:-10

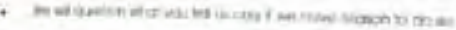

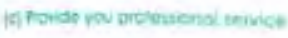

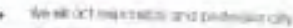

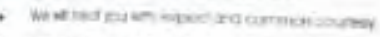

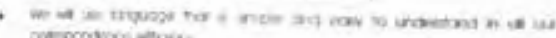

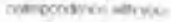

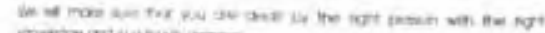

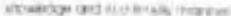

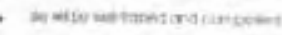

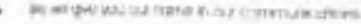

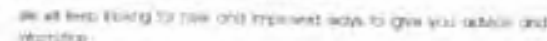
inemissis

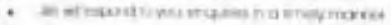


The Charter also states MIRA's service standards in terms of the time within which MIRA expects to provide certain services to taxpayers. These standards are detailed in Table 3.

Table 3: Maldives Inland Revenue Authority's Service Standards

\begin{tabular}{|c|c|}
\hline Service & Standard \\
\hline Registering taxpayers & Within 1 day \\
\hline Registering for GST & Within 1 day \\
\hline Registering for MIRAconnect & Within 3 days \\
\hline Registering a bank account & Within 1 day \\
\hline Changing accounting period & Within 2 days \\
\hline Registering signatories & Within 1 day \\
\hline Request for payment status & Within 1 day \\
\hline Request for tax clearance & Within 2 days \\
\hline Changing taxable period & Within 3 days \\
\hline Changing accounting basis & Within 3 days \\
\hline Registering MIRA approved auditor & Within 5 days \\
\hline Issuing WHT certificate & Within 1 day \\
\hline Responding to 1415 hotline calls & Within 1 day \\
\hline Responding to email queries & Within 2 days \\
\hline Responding to letters & Within 3 days \\
\hline Reviewing objections & Within 45 days \\
\hline Requests for meeting & Within 3 days \\
\hline Updating website & As and when required \\
\hline
\end{tabular}

GST = general Goods and Services Tax, MIRA = Maldives Inland Revenue Authority, WHT = Withholding Tax.

Source: MIRA. 


\section{TAX RULINGS}

As noted in Chapter 3 in the context of the BPT Regulation, the broad language of the taxing statutes passed by Parliament, accompanied by Parliament's preference to leave detailed administrative matters to the tax administrators, requires that the government passes regulations to handle those matters.

In addition, MIRA also issues tax rulings, which set out dicta on the meaning and application of the tax laws. Tax rulings automatically form part of the relevant tax regulation, and are therefore binding upon taxpayers. ${ }^{4}$

Generally, when confronted with a tax issue (which is often raised by a taxpayer or its tax advisor who identifies an ambiguity in the application of the law), MIRA drafts a ruling to address-and, ideally, to resolve-the issue. The draft ruling is subject to a rigorous internal review procedure before it is released for submissions from the public or affected taxpayers, where that is considered appropriate. A finalized version of the ruling is subject to evaluation and approval by MIRA's Technical Committee before it is formally issued.

Since issuing its first ruling on 1 February 2011, MIRA has been particularly vigilant in issuing rulings. Many of them have concerned very complex issues, for the benefit of more sophisticated taxpayers.

\section{PUBLICATION OF GUIDELINES}

In addition to regulations and rulings, MIRA also publishes a number of guides and instructions on completing forms and tax returns, to assist taxpayers in understanding and complying with the BPT and GST laws. Unlike acts, regulations, and rulings, guides are not legally binding upon taxpayers, but are intended to inform taxpayers in user-friendly-rather than legalistic-language. They reflect MIRA's interpretation of (potentially) contentious issues in the tax law. Table 4 lists the guides that MIRA has published since $2011 .^{5}$

\section{Table 4: Guides Published by Maldives Inland Revenue Authority (2011-2015)}

\section{BPT}

Withholding Tax Guide

Guide to Currency and Exchange Rate

Penalties under the GST and BPT Acts

BPT Return Filing Requirements for companies, partnerships and other persons except individuals

BPT Return Filing Requirements for individuals

Taxation of International Air Transportation Services

Section $84(a)$ of the TAA.

Some guides cover both BPT and GST. 
GST Record-Keeping Booklet

GST Food Guide

GST Input Tax Guide

Guide to Zero-rated Goods and Services

Guide to GST and Agency Relationships

Guide to Currency and Exchange Rate

Guide to Third Amendment to the GST Act

Guide to GST on Telecommunication and Courier Services

Penalties under the GST and BPT Acts

Taxation of International Air Transportation Services

\section{Other Taxes}

Green Tax Guide

\section{Tax Administration}

Record Keeping Guide

Taxpayer Registration Guide

Guide to Registration of Rental Income Earners

Guide to Audit

MIRAconnect Guide

Online Payment Guide

Objection and Appeal Guide

BPT = Business Profit Tax, GST = Goods and Services Tax, MIRA = Maldives Inland Revenue Authority.

Source: Author. 


\title{
66 The compliance regime is on the shoulders of SMEs. Taxpayers
} know MIRA is visible. MIRA's [visible] presence is very important. If we don't do that, we won't see the compliance level we have achieved today. In the first 5-6 months, they [SMEs] fully comply, then compliance progressively decreases, until eventually they stop filing. So we need to impose penalties to get them to comply again. We also need to impose penalties to protect good taxpayers. 99

\author{
Yazeed Mohamed \\ Commissioner General of Taxation
}

Compliance visits began with the introduction of the first tax, T-GST, and are ongoing. Staff visits to taxpayers to check taxpayers' compliance with the tax legislation involves pre-visit analyses of the taxpayers' returns, and a review of the issues arising therefrom with the taxpayers on the visits.

It quickly became evident that considerably more taxpayer education was required after the first T-GST, BPT, and GST returns were received and reviewed. Therefore, further compliance check visits to taxpayers were made to ensure correct compliance and prevention of future taxpayer errors, to answer taxpayer queries, and to disseminate circulars and explanatory brochures to taxpayers.

The value of compliance check visits to taxpayers on introduction of a new tax is to:

- provide taxpayer education-leaving the taxpayer with MIRA publications and contact details,

- enhance awareness of the taxpayer's responsibilities,
- explain how to correctly calculate its tax liability,

- emphasize the need for taxpayer voluntary compliance,

- explain the rights, obligations, and responsibilities of taxpayers,

- provide MIRA with the opportunity to address interpretation and practice issues,

- determine the extent of compliance and the degree to which taxpayers correctly understand the operation of the BPT and GST systems,

- sample test the accuracy of taxpayers' accounting systems upon which GST and BPT returns rely,

- answer taxpayer queries,

- build rapport with taxpayers,

- ascertain the level of taxpayer awareness about forthcoming changes to the tax regime,

- give MIRA staff an opportunity to interview taxpayers and review their records, and

- pinpoint areas of policy, statutory interpretation and practice that require attention and, where necessary, correction. 
MIRA's objective is to be accommodating; if subsequently a taxpayer is still noncompliant, penalties are applied.

MIRA recognizes good tax compliance by conferring its Ran Laari (Gold Coin) Award on taxpayers with outstanding compliance. This award, which was first made at MIRA's anniversary function on 2 August 2014, acknowledges taxpayers that pay the highest amount of taxes in accordance with the tax laws and regulations, in individual, corporate, and state-owned enterprise categories.

To address those taxpayers that fail to file the returns and pay tax, MIRA has implemented a reporting system of returns and payments, drawing on the taxpayer registration database. Defaulters are identified and followed up.

\section{AUDIT}

Adoption of the international best practice system of voluntary compliance by taxpayers requires an effective tax auditing operation to ensure that taxpayers are indeed voluntarily complying with the law. Therefore, MIRA established its Audit and Investigation Department (AID) at the outset of the new tax regime. That required building capacity of MIRA staff in tax auditing, developing audit strategies (including audit selection procedures) implementation of full audits and establishing appropriate information technology systems for the department to operate efficiently and effectively.
Modern tax auditing under a voluntary compliance regime requires the application of risk profiling to make a selection of taxpayers to be audited, to ensure that they pay the correct amount of tax. MIRA's initial problem in this respect was that it had no experienced tax auditors. Given the lack of experience, external assistance was required to establish an effective audit department. Therefore, ADB-funded tax audit specialists were engaged to design audit strategies and to compile audit procedure manuals to be used in conducting GST and BPT audits, to design and to develop training material for auditors, and to train MIRA staff on implementing strategies for desk and field audits. 
66 Whilst literacy is high, tax literacy amongst SMEs is not. Many businesses are familyowned and operated, and historically have had no need for or obligation to keep business records. Many businesses, and particularly cash businesses (which dominate the sector) still do not maintain adequate records, making auditing difficult and, as a consequence, exposing taxpayers to indirect (formula assessment) methods of determining income, which can be punitive. 99

Colin Hutchins 

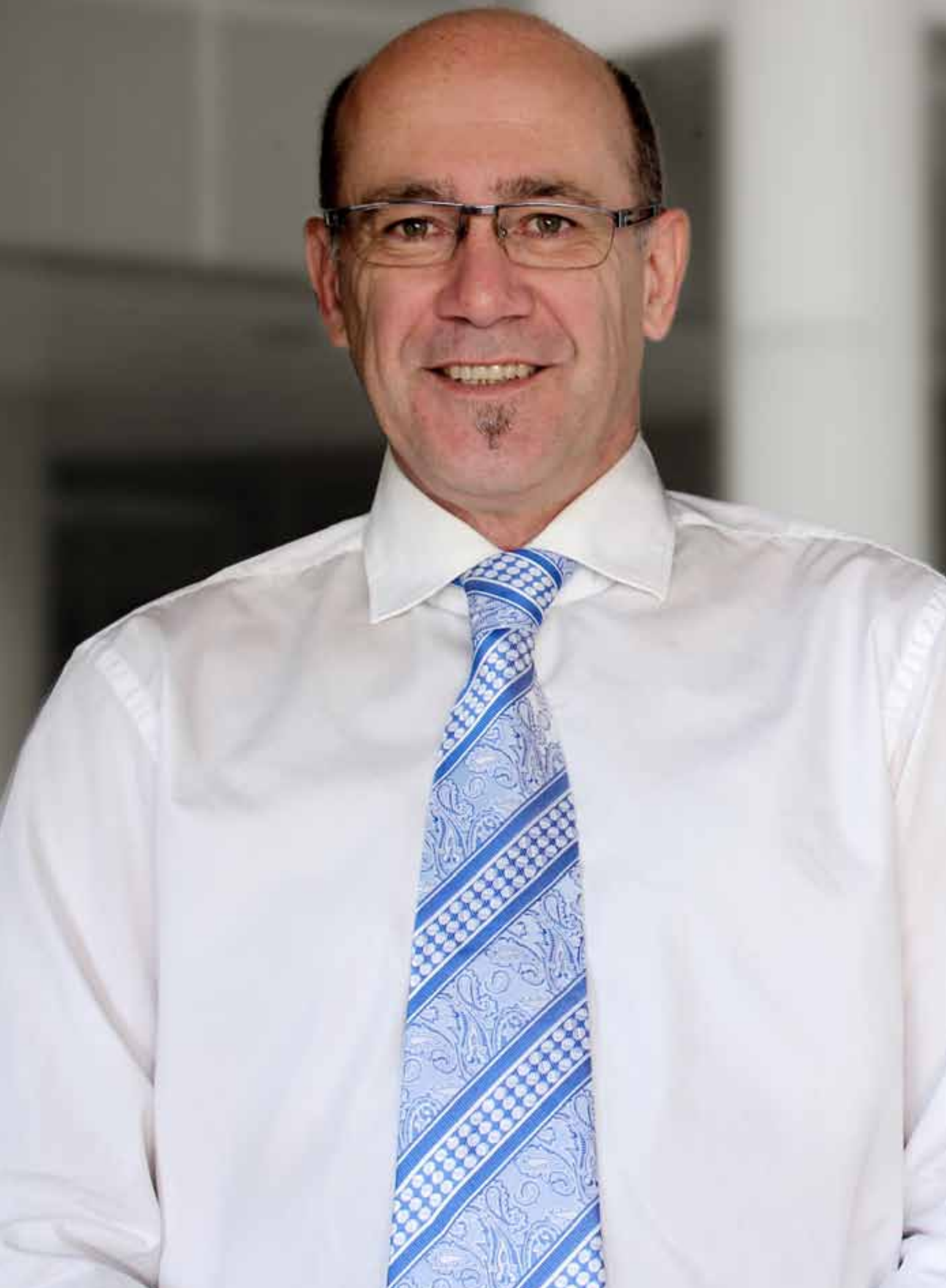


\section{The requirement to have all accounts independently audited was well intentioned but impractical in practice. The small accounting/auditing fraternity in Maldives simply does not have the members to perform the required audits, and efforts to increase the pool of accredited auditors by relaxing the admission criteria have undermined the confidence that can be placed in those audits. 99}

Colin Hutchins

ADB International Audit Consultant to MIRA (2012-2013)

\begin{abstract}
Because BPT is a tax on business profits, it depends on reliable taxpayer financial statements. To ensure the veracity of those statements, they needed to be accompanied by an independent auditor's report. However, the accounting profession in Maldives was only in its formative stage in 2011, and there was a paucity of auditors qualified to carry out the verification work. Even as late as 2008 , DIR officials were bemoaning that no accounting or auditing procedures and standards had been adopted in Maldives. Little progress was made in subsequent years.
\end{abstract}

Nevertheless, if the basis of the determination of a taxpayer's taxable business profits was to have any credibility at all, it needed to be subject to external evaluation. As a measure to ensure the integrity of financial statements submitted to MIRA, minimize bogus audits, and address the lack of availability of fully qualified auditors, since April 2012, MIRA has required that taxpayers' financial statements comply with International Financial Reporting Standards and are audited by suitably qualified people who are registered with MIRA. ${ }^{6}$

BPT taxpayers are classified into four classes depending on their turnover (large, medium-sized, small, and micro), and auditors are classified into three categories (A, B, and C) depending on their qualifications and experience. The relevant class of auditor must match the class of taxpayer. Micro businesses (i.e., businesses with an annual turnover of less than $\mathrm{Rf} 5$ million $)^{7}$ are not required to appoint an auditor.

By the end of 2015, there were 38 registered auditors (4 in Category A, 7 in Category B, and 27 in Category C).

\footnotetext{
Tax Ruling Number TR-2012/B5, superseded by TR-2015/B39, which in turn has now been superseded by TR-2015/B49.

Approximately $\$ 325,000$.
} 
66 Foreign taxpayers avoid tax on foreign sales by transfer pricing. The tourism industry has agreed that this must stop, and we have their backing in taking action against it. If we don't, it will spread to all large taxpayers, including domestic taxpayers who will use foreign companies to do the same thing. MIRA is developing its risk profiling further to address these problems. We also respond to these sorts of issues through regulations. This is important because the tax system is on the shoulders of $10 \%$ of all taxpayers. 99

\author{
Yazeed Mohamed \\ Commissioner General of Taxation
}

More than $70 \%$ of tax revenue collected by MIRA is received from large taxpayers. MIRA's Large Taxpayer Services Department was established on 1 January 2014 to liaise with, check the compliance of, and audit large taxpayers. Generally, large taxpayers are determined by reference to their size and ownership structure. All large taxpayers are audited each year.

\title{
OBJECTIONS AND APPEALS
}

Once the new taxes were being implemented, and audits were being conducted, MIRA began to issue tax assessments. Since these assessments could be challenged by taxpayers, an Objection Unit within MIRA and objection and appeals procedures were established to deal with taxpayers' objections.
A legal team was formed to handle appeals to the Tax Appeal Tribunal (TAT) when taxpayers' objections are disallowed by MIRA, and to pursue unpaid taxes through the courts. 


\section{TAX APPEAL TRIBUNAL}

The Tax Appeal Tribunal (TAT) was established in 2010 under Chapter 6 of the TAA. TAT is the court of first instance in tax disputes. It comprises five members. Its decisions may be appealed in the High Court.
The TAT Regulation was gazetted on 30 April 2012. It deals with matters related to TAT's composition, jurisdiction, and powers; warrants; appeal procedures and hearings; and decisions. MIRA provided input into writing the TAT Regulation and to training its staff.

The tax recovery sequence, which MIRA applies, is:

1. Deferred payment arrangements

2. Access to bank accounts

3. Recovery from third parties

4. Skip tracing

5. Civil suit

6. Seizure of land and other property

- Enforcement policy (2011, updated in 2015)

- Policy on Disclosure of Noncompliant GST Registered Persons (2012)

- Policy on Skip Tracing Persons with Outstanding Payments (2012)

- Policy on Accessing Information of Bank Accounts of Taxpayers and Freezing their Bank Accounts (2012)

- Policy on Dealing with Persons that Issue Dishonoured Cheques to MIRA (2012).
In addition, in 2011, Public Finance Circular No. 2011/07 was issued by Ministry of Finance and Treasury (MoFT), requiring confirmation from MIRA that no outstanding amounts are payable to the government, before any Ministry enters into or amends an agreement with, or issues or amends a license of a person. 
66 Recordkeeping is the big problem. Licensed tax agents are assisting taxpayers to keep records. They are performing a bookkeeping role. 99

\author{
Hassan Zareer \\ Deputy Commissioner General of Taxation
}

MIRA recognizes the significant role that licensed tax agents (LTAs) play in ensuring that the new Maldives BPT and GST regimes operate efficiently and in accordance with the law. LTAs are effective intermediaries between taxpayers and MIRA to help taxpayers to understand the law and to meet their tax obligations. LTAs can enhance the efficiency of the tax system and ensure that taxpayers adopt proper tax compliance habits. It is more effective use of MIRA's limited resources to deal with one person representing many taxpayers than to deal with each of those taxpayers individually.
This role of LTAs is provided for in the TAA. ${ }^{8}$ In addition, section 74 of the BPT Regulation permits tax agents licensed by MIRA to prepare accounts and file tax returns on behalf of taxpayers that fall under the BPT Act.

The Tax Agents Regulation ${ }^{9}$ provides for the licensing of two categories of tax agent with MIRA, and sets out the details and scope of their work, their qualifications, appointment procedures, removal, and code of conduct. By the end of 2015, there were 19 LTAs.

\title{
66 The business community wasn't ready for tax. They don't
} keep records. They work from their houses. They use informal business practices. Therefore, MIRA has given fine relief arrangements to SMEs because they found it difficult to comply with the tax system. But even though they had been operating like that, more are putting in systems and hiring agents. There has only been MIRA to help taxpayers, and that is not enough. We need more public auditors and tax agents. This also increases job opportunities in society, and gives people an alternative to going for government jobs. To encourage that, they can be part-time auditors and agents in the meantime. 99

Yazeed Mohamed

Commissioner General of Taxation

Section 25 of the TAA.

9 Regulation Number 2014/R-36, gazetted on 18 June 2014. 


\section{REVENUE ESTIMATES AND REPORTS}

Transparency is critical to maintain public confidence in the tax system. Consequently, MIRA publishes regular revenue reports and variance reports (of actual collections vs. budgeted estimates), as well as provides tax revenue statistics to MoFT for budgetary and monitoring purposes.
The first Monthly Revenue Report was issued on 15 February 2011 and the first Quarterly Report on 26 April 2011. MIRA published its first Annual Report on 31 May 2012. In addition to tax collection data, the quarterly and annual reports provide information about MIRA's activities and service performance.

\section{LIAISON WITH OTHER GOVERNMENT BODIES}

To carry out its audit and intelligence gathering work, to facilitate the exchange of information and to broaden staff training opportunities, MIRA entered into memoranda of understanding (MoUs) with other Maldives government agencies, including:

- Maldives Customs Service

- Maldives Police Service
- Anti-Corruption Commission

- Department of Immigration and Emigration

- Maldives Pension Administration Office

- Department of National Planning

- Department of National Registration

\section{There is a clear need for Maldives to enter into double tax treaties and/or information exchange agreements with key countries, to ensure that they can cooperate with, and seek the assistance of, other tax authorities to address transfer pricing and other base erosion practices. 99}


Since Maldives is an open economy, which is dependent on international tourism business and foreign investment, from the outset MIRA adopted an international outlook in its administration of the new tax system. This involved entering into international tax agreement negotiations to facilitate ease of crossborder commerce.

MIRA compiled a benchmark model double tax agreement (DTA) and model tax information exchange agreement (TIEA) for Maldives, and commenced DTA negotiations with India, Italy, Qatar, Singapore, Sri Lanka, and the United Arab Emirates, and TIEA negotiations with the Czech Republic, India, the Republic of Korea, and Ukraine. MIRA also addressed the tax aspects of proposed air services agreements with Hong Kong, China and Sri Lanka, and investment promotion and protection agreements with Sri Lanka and Turkey.

International memberships and affiliations are vital in the globalized tax world for tax administrations to enhance their international tax knowledge, ensure that they are conversant with international best practice, and for the exchange of ideas and experiences. MIRA is therefore a member of the International Bureau of Fiscal Documentation, International Fiscal Association, Commonwealth Association of Tax Administrations, Association of Tax Authorities of Islamic Countries, and SAARCCompetent Authorities on Avoidance of Double Taxation and Mutual Administrative Assistance in Tax Matters. MIRA is also an observer at the Study Group on Asian Tax Administration and Research.

It is to MIRA's credit that, despite having existed for only 3 years, SAARC Member States placed confidence in MIRA to draft a SAARC multilateral DTA. In addition, MIRA also took an active role in the formulation of the draft SAARC multilateral air transport agreement.

In 2013, MIRA signed an MoU with the Inland Revenue Board of Malaysia to provide cooperation and assistance in capacity building and training of MIRA employees.

\section{IT REQUIREMENTS}

Upgrading of MIRA's IT systems was required to facilitate the efficient administration of the new taxes. That involved an overall assessment of the extant level of automation across MIRA and the quality of existing systems; defining a roadmap for the automation of processes and procedures for tax administration; developing a tax database and tax audit system for the establishment of AID; and building the capacity of operational and IT staff within MIRA in the use and maintenance of the IT systems. Specific attention was given to the information systems security plan and contingency plan, reporting of security incidents, maintenance of data integrity, and annual protection assessments.
Rather than purchase a commercial off-the-shelf IT solution as was originally intended, in September 2010 MIRA decided to leverage the SAP Enterprise Revenue Planning system-i.e., a business management system-which was implemented in MoFT in 2008. This necessitated the installation of an additional Public Sector Collection and Disbursement engine to cover revenue collection to meet MIRA's additional workload. SAP tax information management system developments initially focused on returns and payments processing procedures, and (exception) reports based thereon, with referral to AID for follow-up action. SAP reconfigured the T-GST module of MIRA's IT system to accommodate the subsequently introduced general GST. 


\title{
66 The business perception of MIRA is good. It is seen as the first government institution that is independent and professional. It is young and energetic and uses modern technology. 99
}

\author{
Arshad Jameel \\ Managing Partner, Urban Stitch Partnership, Male', and Consultant to \\ President's Office 2008-2011
}

Work on implementing the SAP Tax Revenue and Management (TRM) System commenced in 2011. However, work on the project was halted temporarily in June 2011 pending the outcome of the proposed changes to the tax system, described in Chapter 3. The TRM System became operational in December 2012.

Components of the SAP package were:

- Taxpayer registration

- Filing compliance

- Returns processing

- Revenue accounting

Comprehensive sample user testing programmes based on MIRA's business requirement were carried out. A $100 \%$ data migration check was made, involving the participation of all MIRA staff. Some data migration errors were detected, which were checked by a MIRA team.

In 2013, modules were added for managing the recording and collection of resort land rent, long-term agricultural leased island land rent, company and cooperative society annual fees, and vehicle fees. In addition, in collaboration with the National Centre for Information Technology, visa fees began to be accepted through the internet in 2013.

As business with taxpayers is increasingly transacted via telecommunications, it is essential that a proper record of communications is maintained between MIRA and taxpayers. This is vital for telephone communications, where disputes can easily arise about what was said in a telephone conversation. To circumvent these sorts of problems, and as part of the broader enhancement of MIRA's communications structure to incorporate newly opened branches, an automatic 1415 hotline call routing system was also introduced in 2013, which logs and records communications between taxpayers and MIRA.

In 2014 , financial assistance of $\$ 850,000$ was provided by the Government of Japan, via ADB, to fund the establishment of a Customer Relations Management system, which is a taxpayer communications system linking to the TRM system.

In addition, reporting and analytics using SAP Business Objects (Dashboards), covering e-filing and e-services, were installed. Pilot testing of taxpayer online access was also undertaken.

To effectively maintain the SAP system for automated tax administration functions, including support to the help desk and improving technical requirements (such as security and remote access), the IT staff complement was expanded. Comprehensive user training and postimplementation support was provided by SAP.

Nowadays, IT staff develop in-house applications to automate MIRA tasks. 


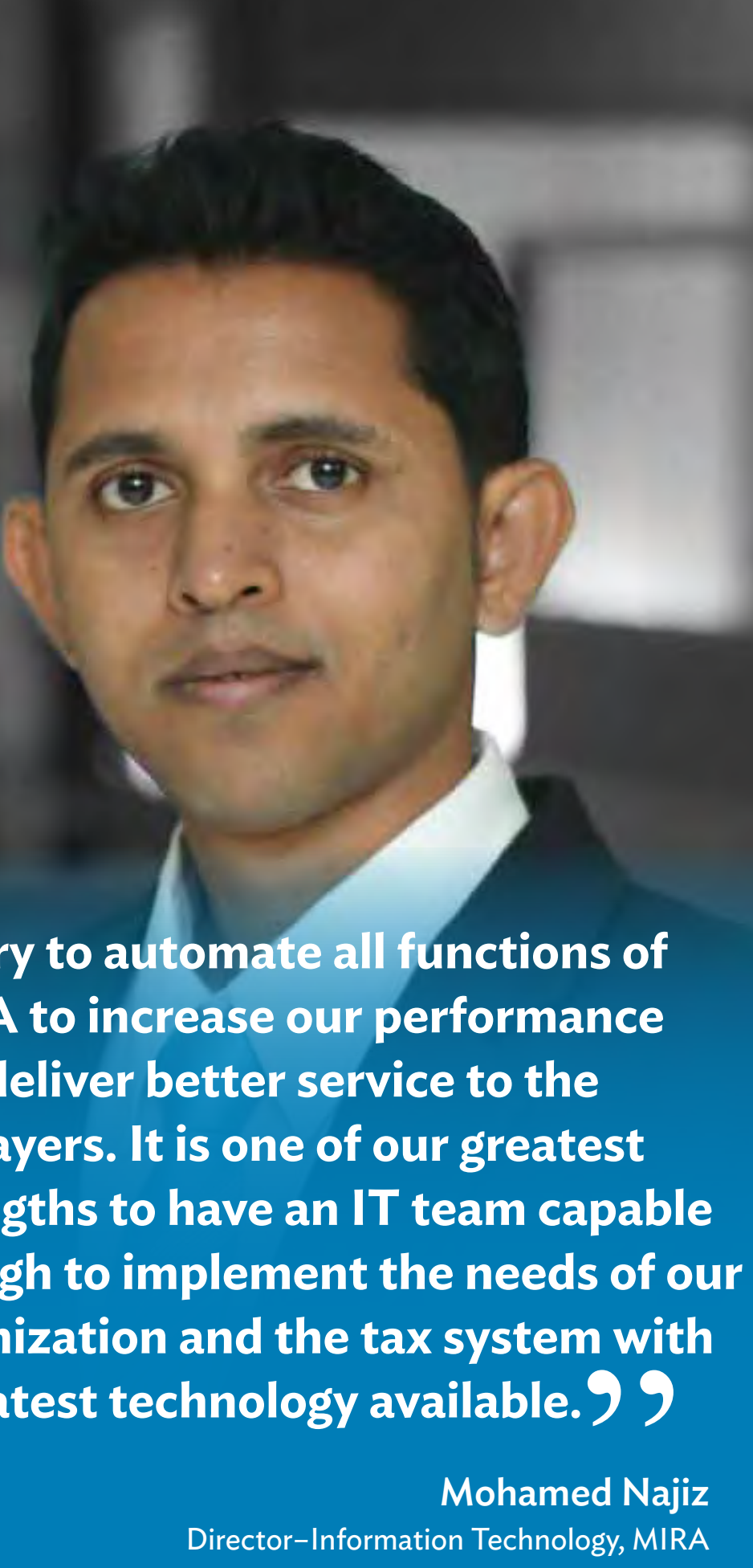




\section{Special consideration was given in forming a tax system with the cooperation of taxpayers to provide efficient services to taxpayers and also provide a system that would facilitate the fulfillment of their responsibilities. 99}

Yazeed Mohamed

Commissioner General of Taxation

\section{Box 9: Maldives Inland Revenue Authority's Core Values}

- Fairness: Apply the tax laws impartially and equitably

- Professionalism: Be exemplary in providing services by applying the applicable knowledge and wisdom

- Integrity: Maintain moral and ethical standards under all circumstances

- Neutrality: Be unbiased in carrying out the obligations in the tax laws

- Transparency: Be an organization which is open to taxpayers and transparent to all

\section{Lessons}

MIRA learned that the key areas in designing an administration system for a new tax are to:

1. properly plan the implementation,

2. develop internal operational and administrative procedures,

3. undertake a training needs analysis,

4. develop training materials,

5. plan and deliver training (and evaluate the effectiveness of the training),

6. maintain public trust in the tax system,

7. instill in staff the importance of keeping taxpayer information confidential, 
8. design a comprehensive taxpayer awareness campaign,

9. ensure that a comprehensive taxpayer registration database is compiled, using corroborating data from other government registration agencies and intelligence from the tax authority's existing information,

10. invest in taxpayer service centers and public awareness programs, to educate and assist taxpayers to meet their obligations and to understand their rights under the new tax laws,

11. ensure that the taxpayers have, or are educated to adopt, proper recordkeeping systems to support voluntary tax compliance,

12. publish a Taxpayers' Charter, which sets out taxpayers' rights and obligations and the tax administration's service standards,

13. regularly publish tax rulings and guides to assist taxpayers to interpret the law and to understand the tax administration's interpretation of it,

14. institute a compliance monitoring regime, including compliance visits to taxpayers,

15. carry out audits on samples of taxpayers, which are selected using risk profiling techniques,

16. engage external expertise if auditors are inexperienced,

17. identify large taxpayers, which are critical to revenue collection performance, and establish a dedicated unit to deal directly with all tax matters relating to them,

18. ensure that robust enforcement policies are developed and published,

19. enhance the level of taxpayer compliance and to utilize the tax administration's resources more effectively,

20. introduce an LTA regime, allowing tax agents to act as intermediaries between taxpayers and the tax administration,

21. provide the public with monthly, quarterly, and annual reports of the tax authority's performance,

22. ensure that the privacy provisions of the taxing statutes permit exchange of information between the tax authority and other domestic government bodies and foreign tax authorities,

23. quickly progress DTA and TIEA negotiations with trading and investor partner countries,

24. become affiliated with international tax bodies to facilitate exchange of knowledge and to take advantage of training opportunities, and

25. implement a modern online-based IT system appropriate to the tax administration's needs. 


\section{CHAPTER 5}

\section{Some Unique Difficulties \\ and Challenges of Implementation}

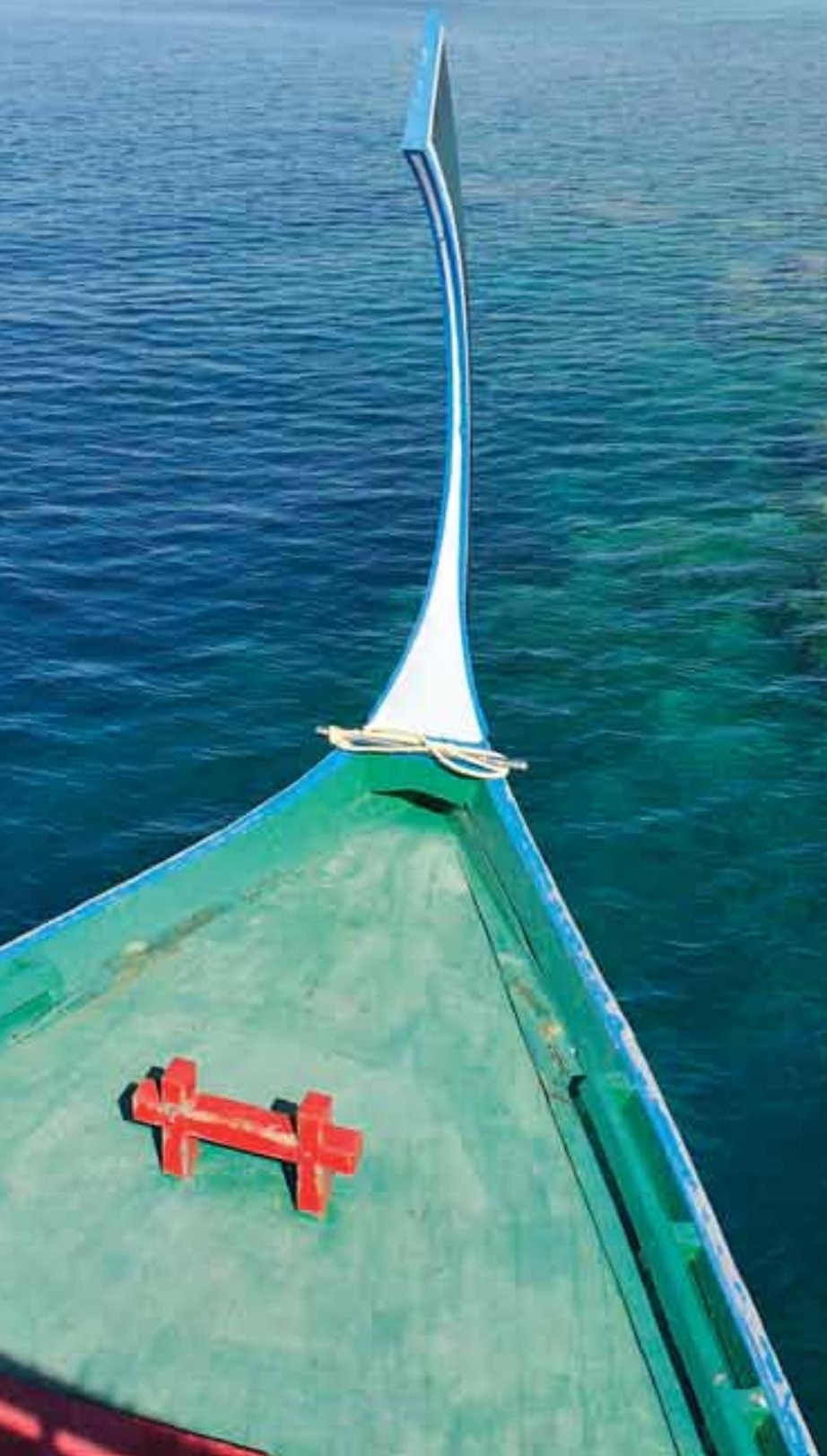

W. 


\section{FOUR PARTICULAR IMPLEMENTATION CHALLENGES}

This chapter highlights four unique challenges faced by Maldives in implementing its new tax regime:

1. The dichotomized economy

2. Changing government priorities and the time constraint

\section{DICHOTOMIZED ECONOMY}

The Maldives economy is dichotomized. This means that the economy comprises two broad categories of activity. For convenience, taxpayers from each category will be referred to as Group A and Group B.

Group A consists of a highly developed and sophisticated tourist resort sector comprising many international operators, which are often part of a multinational group of companies, and other significant sectors of the economy, including banks, large construction companies, and state-owned enterprises.

At the other end of the spectrum, Group B comprises a relatively unsophisticated small business sector, a significant proportion of which are cash-based undertakings. While other taxpayers fall more toward the middle of the spectrum, their significance is far less than those in groups $A$ and $B$.

The dichotomized nature of the Maldives economy poses challenges for tax administration. Members of Group A generally have reliable accounting systems, which allow for fairly ready compilation of their tax liabilities, but they have historically enjoyed tax-free status in Maldives. The introduction of Business Profit Tax (BPT) and (to a lesser extent) Goods and Services Tax (GST) has imposed an additional cost of doing business, which, like all operating costs, needs to be managed and, where possible, minimized. While the tax rates in Maldives are modest by international standards, they are nevertheless a significant step away from the former tax-free status and indeed the effective global tax rates borne by many multinational businesses.

\section{Policy and legislative shortcomings}

4. Taxpayer voluntary compliance and selfassessment

This chapter will also consider how external experts assisted in combating these difficulties.

Typically with the assistance of their professional advisors, Group A taxpayers are inclined to take more aggressive tax positions and to enter into tax mitigation arrangements, by adopting a range of structural, funding, and pricing measures which minimize their domestic tax impost and potentially fall foul of the Maldives international transfer pricing and antiavoidance rules. The challenge for Maldives Inland Revenue Authority (MIRA) is to determine how, with limited resources and relatively inexperienced tax auditors, it tackles these well-resourced multinational businesses, particularly when

- the local branch or entity itself has little or no control over head office funding, administrative charges, and pricing strategies;

- MIRA has limited access to records stored and controlled offshore; and

- there is a lack of comparative data to assess whether related-party transactions are taking place at arm's length.

Group A taxpayers require MIRA to invest extensively in staff development to cope with the arising technical and legal interpretation issues, which highlight the need for the government to develop a comprehensive network of tax information exchange agreements, including membership of the Organisation for Economic Co-operation and Development (OECD) Global Forum on Transparency and Exchange of Information for Tax Purposes. 
Group B requires MIRA to embark on large-scale taxpayer education and awareness programs, including the need to train taxpayers to keep basic business records, a practice foreign to long-time businesspeople who carry out all of their business transactions in cash and do not keep any formal accounting records. Rather than producing tax avoidance problems for MIRA, Group B manifests tax evasion and fraudulent practices, which require MIRA to develop skill sets appropriate to addressing such criminal activity. For this purpose, with the assistance of the Maldives Police Service, MIRA staff have been trained in forensic investigation techniques.

Fortunately, because of the exemption from BPT for annual taxable profits of less than Rf500,000, many of the country's numerous small businesses fall outside the BPT regime. ${ }^{1}$ This outcome is logical from the perspectives of both tax equity (not taxing low-income earners) and tax compliance (since even greater tax and accounting education and tax policing resources would be required if they fell within the tax net).

Nevertheless, many small operators do fall within the ambit of GST and, as a consequence, they need to instigate or improve their transaction-recording mechanisms. Section 103 of the GST Regulation stipulates that documents could be maintained without the use of software until 31 December 2011. In an effort to encourage small businesses to adopt recordkeeping software, the government consideredand publicly announced-a proposal to provide taxpayers with software to maintain business records, either at no cost to taxpayers or by way of soft loans. While the government was contemplating this idea, MIRA visited 230 businesses in 2011 to gather information about software they use. As a result, MIRA issued a series of tax rulings, which extended the period allowed to taxpayers under section 103 of the GST Regulation to maintain records without the use of software to 30 June 2012, ${ }^{2}$ then to 31 December $2012,{ }^{3}$ and then removing the time limit altogether, instead requiring that records maintained without the use of software be done so in accordance with specimen records issued by MIRA. ${ }^{4}$

It is unfortunate that the government was unable to proceed with its initiative since it would have brought an immediate marked improvement to the general standard of small business recordkeeping in Maldives and buttressed revenue collection from that source. It was the sort of worthwhile project that lent itself to international funding from aid agencies, especially given the relatively small population of businesses in Maldives. ${ }^{5}$ In the event in 2011 MIRA distributed GST recordkeeping books to 570 businesses.

More generally, once a businessperson knows from their accounting records and statements how the business is actually performing, they are in a far better position to make rational and timely business decisions. This point is particularly relevant in Maldives, given its high turnover of business operations.

\title{
66 There are not enough auditors on the island, so it is a huge expense to get audits done. Also, we paid a huge amount for technical systems support after we were first told that MIRA would give GST software to businesses. 99
}

\author{
Anwarusalam Aboobakuru \\ Chief Operating Officer, Biyalanco, Kulhudhuffushi
}

\footnotetext{
Section $7(\mathrm{e})$ of the BPT Act.

Tax Ruling Number 220-PR/TR/2011/4 (18 December 2011).

Tax Ruling Number TR-2012/G6 (7 June 2012).

4 Tax Ruling Number TR-2012/G10 (13 December 2012).

5 In this respect, it is worth noting the approach of the Republic of Korea to plugging GST revenue leakage by requiring businesses to record electronically with the tax authority transactions that are subject to GST. This ensures that the tax authority has a record of GST output tax paid, which can be matched automatically against GST input tax credits claimed.
} 


\section{6 "On the plus side, those SMEs that have introduced}

recognized accounting packages, and who have adopted good record-keeping practices, have enjoyed the indirect, nontax benefits of:

- better information to assess and improve the performance of their business operations

- the ability to identify business risks and opportunities which may otherwise have gone unnoticed

- more accurate assessment of the value of their businesses, enabling them to seek additional capital and access loans to develop their businesses, and to realistically assess business opportunities (i.e., acquiring new businesses or disposing of underperforming activities). 99

Colin Hutchins

ADB International Audit Consultant to MIRA (2012-2013)

\section{CHANGING GOVERNMENT PRIORITIES AND THE TIME CONSTRAINT}

When Parliament passed the BPT Act on 30 December 2010, the BPT regime was expected to take effect from 1 January 2012. ${ }^{6}$ However, the government decided to implement the law from 18 July 2011. That decision necessitated a reordering of priorities, resulting in MIRA diverting resources toward, and concentrating on, establishing effective mechanisms to administer BPT. This predominantly involved the urgent compilation, passage, and release of the BPT Regulation before the BPT regime took effect, at the same time as it was required to address interpretation and practice issues in the application of the Tourism Goods and Services Tax (T-GST) regime.

However, this redirection of MIRA resources toward BPT was complicated by two matters: (a) An action was filed in the High Court against the state challenging section 77 of the BPT Regulation, which defined "date of commencement of the Act" to mean 18 July 2011. The plaintiff contended that the proper interpretation of the act required implementation on 1 January 2012. The BPT collectable for the period 18 July 2011 until 31 December 2011 (including withholding tax, which has already been collected) was at risk if the plaintiff succeeded. As it happened, the court has never issued a decision and the plaintiff ultimately withdrew the case, but the practical effect was that MIRA needed to promulgate the BPT Regulation (which it did by publication in the Government Gazette on 18 August 2011, after approval by the Attorney General), not actually knowing whether

Section 41 of the English translation of the BPT Act. 
the presumption in the regulation of a commencement date of 18 July 2011 was valid.

(b) In July 2011, the government changed its tax reform implementation priorities when it decided that GST would be introduced from 1 October 2011 and that Corporate Profit Tax (CPT) and Personal Income Tax (PIT) would be implemented from 1 January 2012. As a result, the T-GST Act and T-GST Regulation were repealed with effect from 2 October 2011, and the BPT Act and BPT Regulation were to be repealed from 1 January 2012. This change in the order of the government's priorities again necessitated a change in MIRA's priorities. This was particularly the case with GST.
The Maldives Chamber of Commerce challenged the introduction of the GST regime itself in the High Court, primarily on constitutional grounds. ${ }^{7}$ Ultimately, the Chamber of Commerce withdrew its case, but again the practical effect was that MIRA was required to marshal resources into establishing the GST regime, including compiling and issuing the GST Regulation (which it did by publication in the Government Gazette on 1 October 2011, just a day before the commencement of the GST regime) once more not actually knowing whether the court would uphold the constitutionality of this tax.

\section{POLICY AND LEGISLATIVE SHORTCOMINGS}

A number of policy and legislative drafting deficiencies have resulted in a loss of revenue to the government and an allocation of a disproportionate amount of MIRA resources to address them. Four examples illustrate the tax policy deficiency:

1. Allowing BPT deductions when there is no corresponding assessment of the amount deducted. This problem manifests itself in two primary ways:

- Businesses are allowed a deduction for remuneration paid to persons associated with the business (e.g., directors, shareholders, and partners) up to a predetermined limit but, in the absence of a tax on personal income, the government receives no tax on those amounts in the hands of the recipient. Deductions always result in a loss of tax revenue for the government. Tax symmetry requires that the amount deducted is taxed elsewhere.

- Similarly, interest is deductible by a business (sometimes subject to a cap). Because interest received by a lender who is not in business is not taxed, tax avoidance arrangements are encouraged by manufacturing artificially large loans from people associated with the business, to maximize the interest deduction and simultaneously augment the nontaxable amount derived by the lender.

2. Withholding tax (WHT) is not levied on interest payments to foreign lenders.

As mentioned earlier, the tax saving arising from a deduction claimed by a business for interest paid to a foreign lender leaves the government in a net "loss" position.

3. Irrational classification of some GST-exempt and zero-rated goods and services.

- The inclusion and exclusion of goods in Schedule 1 (Zero-Rated Essential Goods) of the GST Act is not based on rational, transparent criteria: some goods that are included are questionable (e.g., adult diapers), while the reasoning behind the omission of others is unclear (e.g., toilet paper). Furthermore, from a tax policy perspective, it is simply illogical to exemptrather than zero-rate-international transportation services. ${ }^{8}$

4. The failure to include imports within the GST net. The international norm is to require GST to be imposed on imports to ensure tax neutrality between foreign supplied goods and services and competing local supplies. The absence of GST on 
imports requires additional compliance and audit resources to be allocated to ensure that importers (which are required to be registered for GST purposes) are not able to circumvent their GST liabilities by applying their imported goods and services to uses other than making taxable supplies, e.g., for own private consumption or to make GSTexempt supplies. The omission also opens up opportunities for "carousel fraud." In addition, the opportunity to utilize the GST regime as a check on the veracity of valuations declared by importers for customs duty purposes was missed.

Section $6(a)(4)$ of the BPT Act, ${ }^{10}$ which attempts to define the WHT base, illustrates how poor legislation drafting results in difficulties for tax administrators. ${ }^{11}$ The section is written so broadly that, in many circumstances, it defies practical application.

More fundamentally, section 4(a) of the BPT Act fails to clearly establish whether or not the taxable profits of a noncorporate business encompass its foreignsourced profits.
These deficiencies create tax policing difficulties and tax avoidance opportunities, which threaten the tax base and result in

(i) forecasted revenues not being achieved; and

(ii) unnecessary additional government expenditure being required to fund

(a) additional resources to monitor a more complex compliance regime and to interpret incoherent tax legislation,

(b) extra audit and investigation resources for MIRA to detect, monitor, and challenge tax avoidance arrangements, and

(c) more frequent use of legal processes where taxpayers object to MIRA's position.

It cannot necessarily be left to regulations to provide clarification and to fill the gaps in the legislation, since the magnitude of the corrective measures required would render the regulations ultra vires.

9 "Carousel fraud" is the practice of importing goods from a country where they are not subject to GST, selling them in Maldives with the GST added, then deliberately not paying the GST to MIRA.

10 Section 6(a)(4) of the BPT Act states that a "payment of fees for management, personal or technical services and any other commission or fee not constituting income from any employment" is subject to WHT.

11. Law Number 14/2011. 


\section{TAXPAYER VOLUNTARY COMPLIANCE AND SELF-ASSESSMENT}

Maldives adopted the international best-practice approach in the design of tax systems, basing the new tax regimes on the principle of taxpayer voluntary compliance and self-assessment. This approach is enshrined in various parts of the country's tax legislation, e.g., section 17 of the BPT Act. Taxpayer self-assessment means that the taxpayer files a tax return in which he or she calculates his or her tax liability after voluntarily making a full declaration of all income or other amount subject to tax.

For this approach to work properly, taxpayers must be aware of the possibility that they will be audited (to confirm the veracity of their returns and calculations) and that they will be penalized if omissions or miscalculations are detected. This is essentially a carrot-and-stick approach, which relies on a robust penalties regime to act as a deterrent from taxpayers committing tax offenses.

During the course of administering the T-GST Act, the BPT Act, and the GST Act in 2011, it became clear that there were deficiencies in the operation of the Tax Administration Act (TAA). The TAA required amendment to allow MIRA to more effectively counter delinquent taxpayers' resistance to pay tax. Consequently, the First Amendment to the TAA was ratified by the President on 29 December 2011. This amendment act

- augmented MIRA's audit and investigation powers,

- authorized MIRA to freeze the bank accounts of noncompliant taxpayers, and

- empowered MIRA to determine offenses and implement penalties under the tax laws.
The amendment act also gave MIRA the right to issue tax rulings, which automatically amend tax regulations, and imposed obligations on MIRA. It required MIRA to submit annual reports to Parliament and the President and to specify the tax principles required to implement tax laws and regulations.

MIRA spent considerable time on interpretation and application of the amended TAA, particularly the audit, investigation, and tax recovery provisions, which Parliament amended in 2011 in anticipation of the repeal of the BPT Act and the enactment of the CPT and PIT bills. Since that repeal and those enactments have not occurred, there are a number of legal issues surrounding the relationship between the audit, investigation, and tax recovery provisions in the amended TAA and those in the continuing BPT Act. Taxpayers under challenge began citing the legislative inconsistencies in their defense, together with inconsistencies with the Constitution. These inconsistencies highlight a very significant shortcoming in Parliament's ability to pass coherent legislation: the amendment act was passed in December 2011 when it was known that BPT was still in operation-and had been for 6 months.

A further problem with the amendment to the TAA is that the realistic deterrent monetary penalties for tax offenses, which were proposed in the initial amendment bill submitted to Parliament, were significantly diluted by Parliament members before the bill was enacted. An obvious consequence of that dilution is that the enacted penalties became so insubstantial that they failed to achieve their purpose as a punishment for tax offenses and a deterrent for taxpayers tempted to (re)offend. The weak penalties reflect either (or both) a lack of understanding of the concepts of voluntary disclosure and taxpayer selfassessment or the impact of vested interests. 


\section{Lessons}

1. Ensure that tax legislation is simple and clear (at least to avoid disputes about the date of its commencement).

2. Require legal drafters to liaise with tax administrators to write tax law capable of practical application.

3. Tax policy makers need to fully appreciate the tax avoidance opportunities that poorly written tax legislation creates, which results in undermining the tax base.

4. Parliament must ensure that amending legislation which affects, or cross-references, another act is coherent and consistent.

5. Tax legislation must be updated and amended regularly (preferably at least annually), to keep abreast of changes in the commercial environment.

\section{USE OF EXTERNAL EXPERTISE}

To address the challenges faced by MIRA in implementing the new tax regime, the assistance of foreign tax experts was necessary. Through a number of technical assistance (TA) projects between October 2010 and December 2015, Asian Development Bank (ADB) was the predominant international agency advising MIRA and MoFT on policy, technical, structural, and organizational issues. Specifically, support was manifested in the engagement of tax policy, administration, audit, and information technology (IT) consultants, tasked principally with guiding MIRA in the implementation of T-GST, BPT, and GST; strategy development; revenue management coordination; systems implementation; and training. In total, ADB allotted $\$ 4.8$ million for these purposes.

ADB TA was delivered through three key projects:

(i) Institutional Strengthening for Economic Management to

(a) strengthen administration of the new taxes introduced under the ADB Economic Recovery Program and (b) develop the capacity of MIRA to implement the tax measures; ${ }^{12}$

(ii) Developing the Revenue Administration Management Information System (RAMIS) to

(a) develop and install a web-based automated RAMIS,

(b) deliver training programs for tax officials and a public awareness program for taxpayers, and

(c) conduct a study on revenue policies and the regulatory framework for expanding the revenue base and streamlining revenue administration; ${ }^{13}$ and

(iii) Enhancing Tax Administration Capacity to support the government's efforts to

(a) enhance services through customizing a Customer Relations Management system at MIRA,

(b) provide support to tax officials to build MIRA's capacity and to put in place a public awareness program, and

(c) review policies and regulations to expand the country's revenue base. ${ }^{14}$ 
The assistance provided through ADB, by drawing on independent consultants experienced in tax policy, law, and administration, focused on

- advice on technical and procedural issues arising from the implementation of the T-GST, BPT, and GST laws and the TAA, and increasing taxpayer awareness of the correct application of the tax laws;

- developing and implementing a comprehensive and effective approach to raising public awareness of BPT and GST;

- developing clear and comprehensive regulations to ensure smooth implementation of primary tax legislation and to clarify ambiguities in the law;

- compiling detailed systematic operational procedures on how to administer the legislation and regulations, ensuring that MIRA took ownership of the procedures and was capable of continuously developing them as the country's legislative, administrative, and technical environments changed;

- preparing clear, comprehensive, and cogent bills on new and amending legislation for submission to Parliament;

- undertaking comprehensive training programs across all of MIRA's operational functions and compiling training program syllabi;

- developing internal operational procedures as well as tax audit and IT methodologies;

- assisting with the development, implementation, and maintenance of the Tax Revenue and Management and CRM IT systems;
- training and coaching in specific IT project management methodologies;

- supporting MIRA in implementing e-filing and comprehensive e-tax internet-based taxpayer services; and

- on-the-job assistance and training with the desk and field audits.

Because of MIRA's dearth of experience in international tax, the authority benefited considerably from the experience of ADB consultants in assisting it to address complicated international tax issues (e.g., transfer pricing, international corporate restructuring, and permanent establishment issues), in double tax agreement and tax information exchange agreement negotiations, and in determining the tax ramifications of other international agreements into which the government has entered.

The real value to MIRA of ADB's TA in this respect was having consultants "on the ground" on a longterm basis, sitting next to staff daily and working with them to resolve "live" issues as they arose from taxpayers and to be present on taxpayers' premises during the undertaking of audits. This was the basis for effective mentoring, advice, and document reviews, allowing for effective working relationships to be forged with MIRA staff.

Other international agency support was also forthcoming, largely in the form of short-term capacity building and training programs. This support was given principally by the International Monetary Fund, the Inland Revenue Authority of Singapore, and the OECD. 
Table 5: Technical Assistance Projects (2011-2015)

\begin{tabular}{|c|c|c|c|c|}
\hline ADB & IMF & Kuwait Fund & $\begin{array}{c}\text { Temasek } \\
\text { Foundation } \\
\text { (Singapore) }\end{array}$ & OECD \\
\hline $\begin{array}{l}\text { - Diversification of } \\
\text { tax base } \\
\text { - Customized IT } \\
\text { platform } \\
\text { - Public awareness } \\
\text { - Capacity } \\
\text { enhancement in } \\
\text { tax policy and tax } \\
\text { audit }\end{array}$ & $\begin{array}{l}\text { - International tax } \\
\text { compliance } \\
\text { - Transfer pricing } \\
\text { training } \\
\text { - Strategic planning }\end{array}$ & $\begin{array}{l}\text { - International tax } \\
\text { avoidance and tax } \\
\text { evasion } \\
\text { - Managing self- } \\
\text { assessment } \\
\text { - Audit training } \\
\text { - Transfer pricing } \\
\text { training } \\
\text { - Practical aspects } \\
\text { of international } \\
\text { tax planning } \\
\text { - Study tours }\end{array}$ & & $\begin{array}{l}\text { - Transfer pricing } \\
\text { training } \\
\text { - International tax } \\
\text { training } \\
\text { - Tax information } \\
\text { exchange training }\end{array}$ \\
\hline
\end{tabular}

ADB = Asian Development Bank, GST = general Goods and Services Tax, IMF = International Monetary Fund, IT = information technology, OECD = Organisation of Economic Co-operation and Development.

Source: Author.

\section{Lessons}

Engage experienced tax consultants to work with and build professional relationships with staff by providing on-the-job assistance and training on a flexible, long-term basis. 
66 We need [technical assistance] from all areas. We could not do it ourselves. Consultants were not always capable. It is difficult to assess the capacity of consultants through their CVs. We find out their actual ability only when they start. Where they are not the right person for the job, we need to be able to change them immediately. 99

Hassan Zareer

Deputy Commissioner General of Taxation 


\section{CHAPTER 6 Success Factors}

(2) IIINIn)

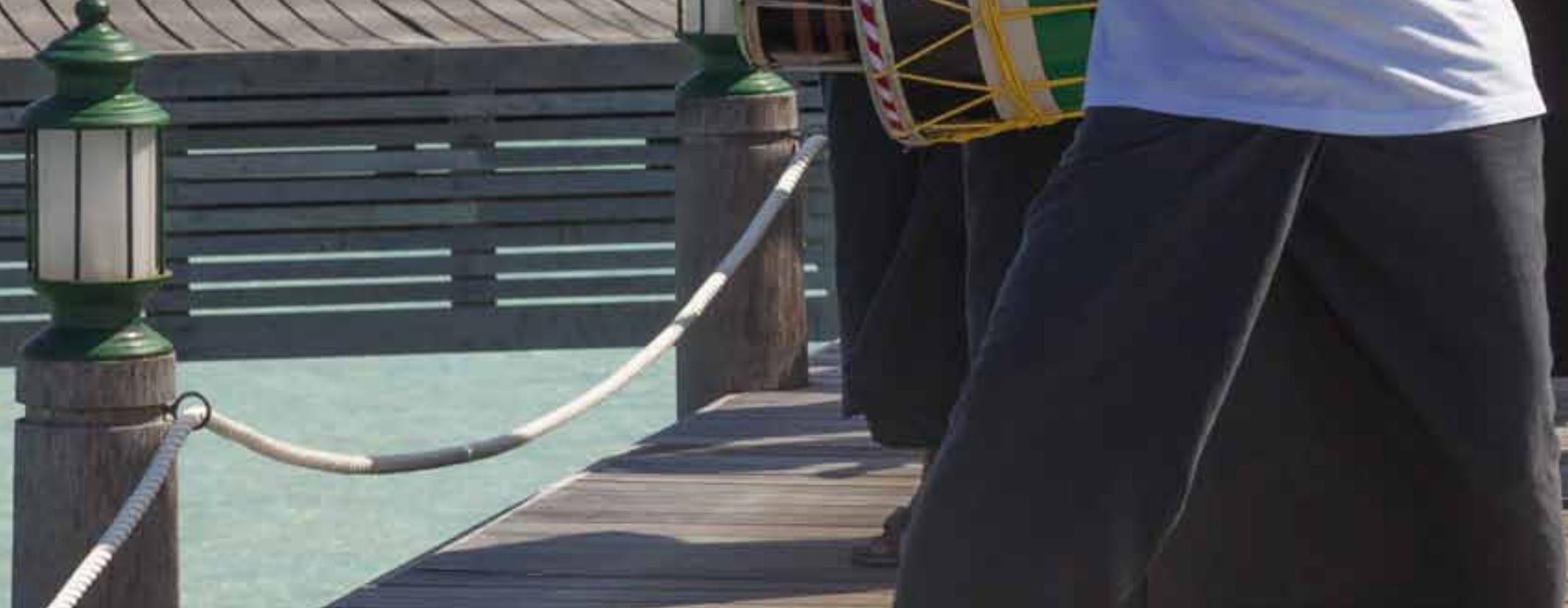




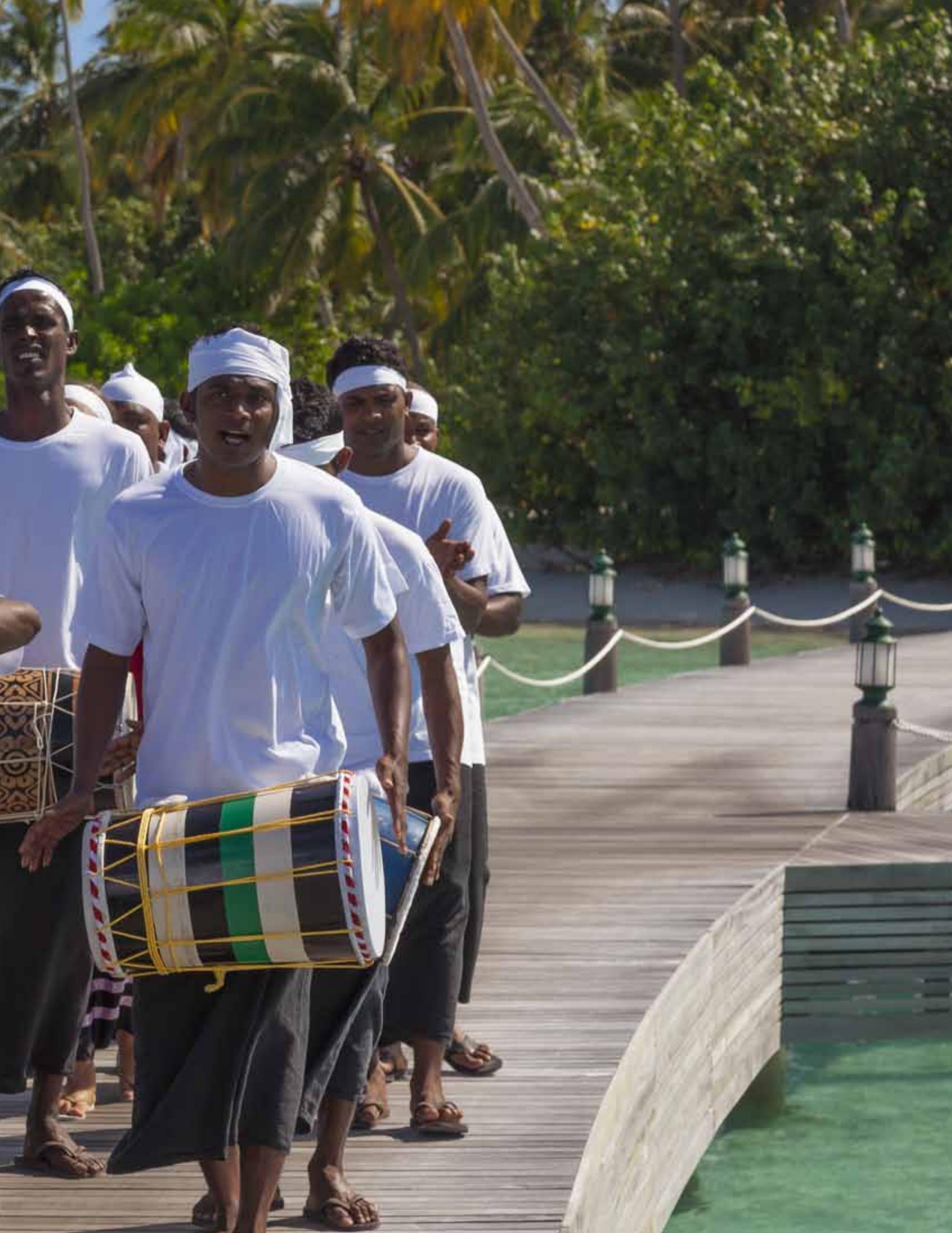




\section{KEY SUCCESS FACTORS}

There is little doubt that the tax reforms in Maldives since 2010 have been successful. The main objective was to increase government revenue, which certainly has been achieved.

Furthermore, Maldives Inland Revenue Authority (MIRA) has been largely successful in its administration of the new taxes. In this respect, the main success factors can be attributed to the following:

- MIRA's leadership; emanating from the Commissioner General, MIRA has adopted a clear long-term strategy and focused on the successful achievement of short-term operational targets;

- MIRA's young, qualified, competent, and motivated staff;

- Intense public awareness campaigns, involving regular media spotlight and atoll visits;

- MIRA's political independence;

- Public trust in MIRA as a professional, nonpartisan institution;

- MIRA's corruption-free status; and

- MIRA's cooperation with other institutions.

66 There have been three success factors of MIRA. First, leadership of CG [Commissioner General], which I have never seen in Maldives before. He explores every possible option. He is the last person to leave the office. We would not have made the achievements we have without him. Second, our young and highly qualified staff. And third, being an independent authority where we were free to do what we wanted in establishing MIRA and its structure. 99

Hassan Zareer

Deputy Commissioner General of Taxation 


\section{REVENUE COLLECTION}

The principal objective of the government's tax reform program was to increase the government's tax revenue collections. Thus, the primary indicator of the success or failure of the reform measures is whether, and to what extent, revenue collections have increased as a result of the reforms. The benefits of the country's modern tax system are clearly evident in the considerably increased government revenue since 2011. This has been supported by MIRA's tenacity in pursuing outstanding dues, both with respect to the post-2010 tax regimes and those amounts owed to the state but uncollected before MIRA came into being.

Total revenue collected during the 6-year period from 2010 to 2015 increased at an annual rate of $43 \%$, from Rf2.41 billion in 2010 to Rf13.06 billion in 2015. As shown in Table 6, the immediate effect of the introduction of the new taxes in 2011 was an $89.2 \%$ increase in tax revenue collected compared with 2010.
The increase in the GST rate from $3.5 \%$ to $6 \%$ on 1 January 2012, and the first full year's collection of BPT and general sector GST were the key reasons for the $56.8 \%$ increase in revenue collected by MIRA in 2012. The T-GST rate increase to $8 \%$ on 1 January 2013 was a significant contributor to the $25.6 \%$ annual increase in tax receipts in 2013. Similarly, the increase in the tourism GST rate to $12 \%$ on 1 November 2014 was a major driver of the $13.6 \%$ increase in tax revenue in 2015.

Moreover, the dramatic growth in tax revenue collected throughout the 2011-2014 period was also on the back of increasing tourist arrivals as well as robust domestic economic activity and development.

Table 6: Total Tax Revenue Collection (2010-2015)

\begin{tabular}{ccc} 
Year & $\begin{array}{c}\text { Total Revenue Collection } \\
\text { (Rf billion) }\end{array}$ & Percentage Increase \\
2010 & 2.41 & 89.2 \\
2011 & 4.56 & 56.8 \\
2012 & 7.15 & 25.6 \\
2013 & 8.99 & 28.1 \\
2014 & 11.50 & 13.6 \\
2015 & 13.06 & \\
\hline Total (2011-2015) & $\mathbf{4 5 . 2 6}$ & $\mathbf{4 2 . 7}$
\end{tabular}




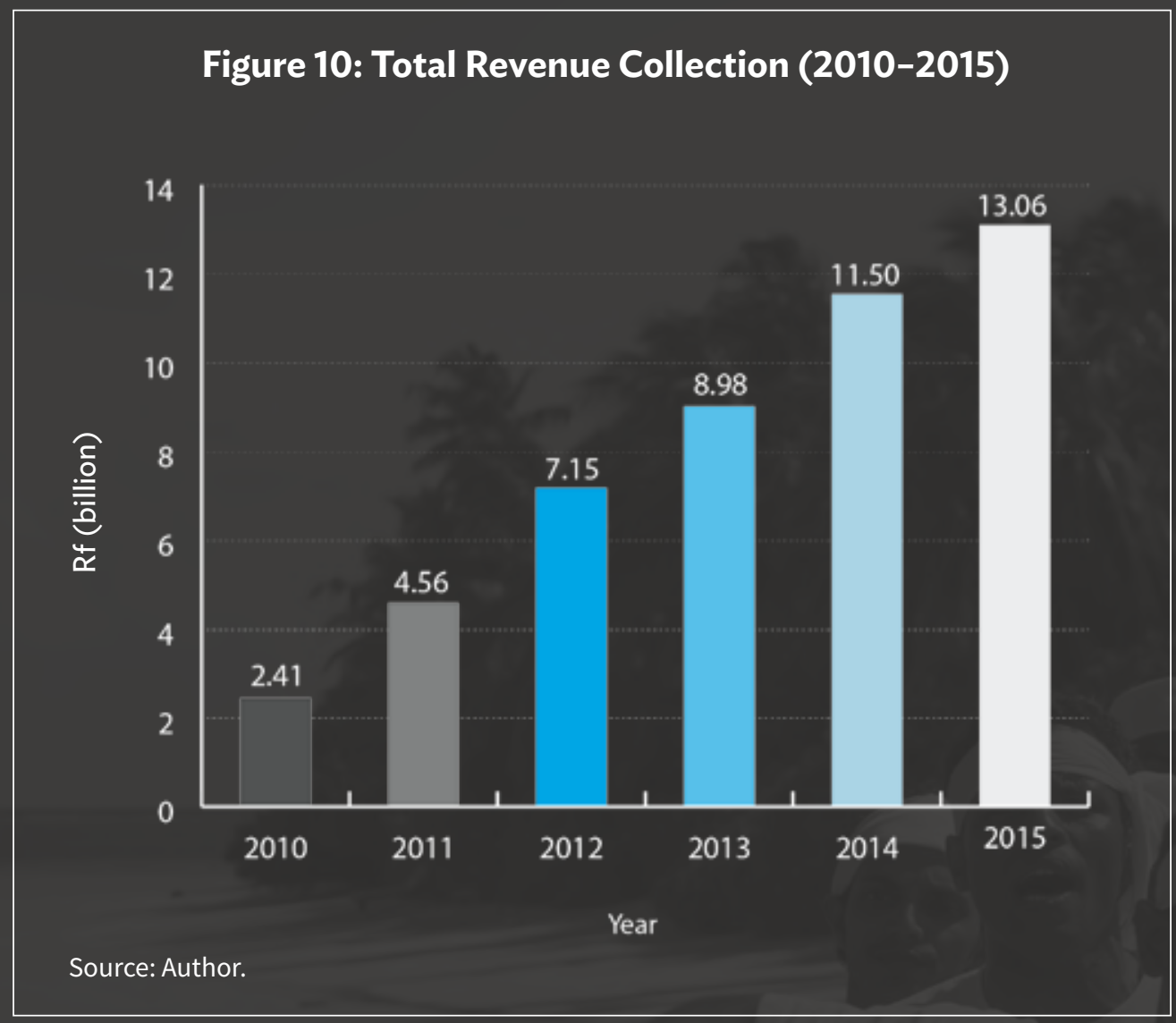

\section{CONTRIBUTION TO STATE COFFERS}

Not unexpectedly, tax revenue collected by MIRA as a proportion of all state revenue increased considerably, especially once the full effect of the reduced import duties was felt. Figure 11 shows that MIRA was collecting $77 \%$ of all of the government's income by 2014, compared with 37\% in 2010.

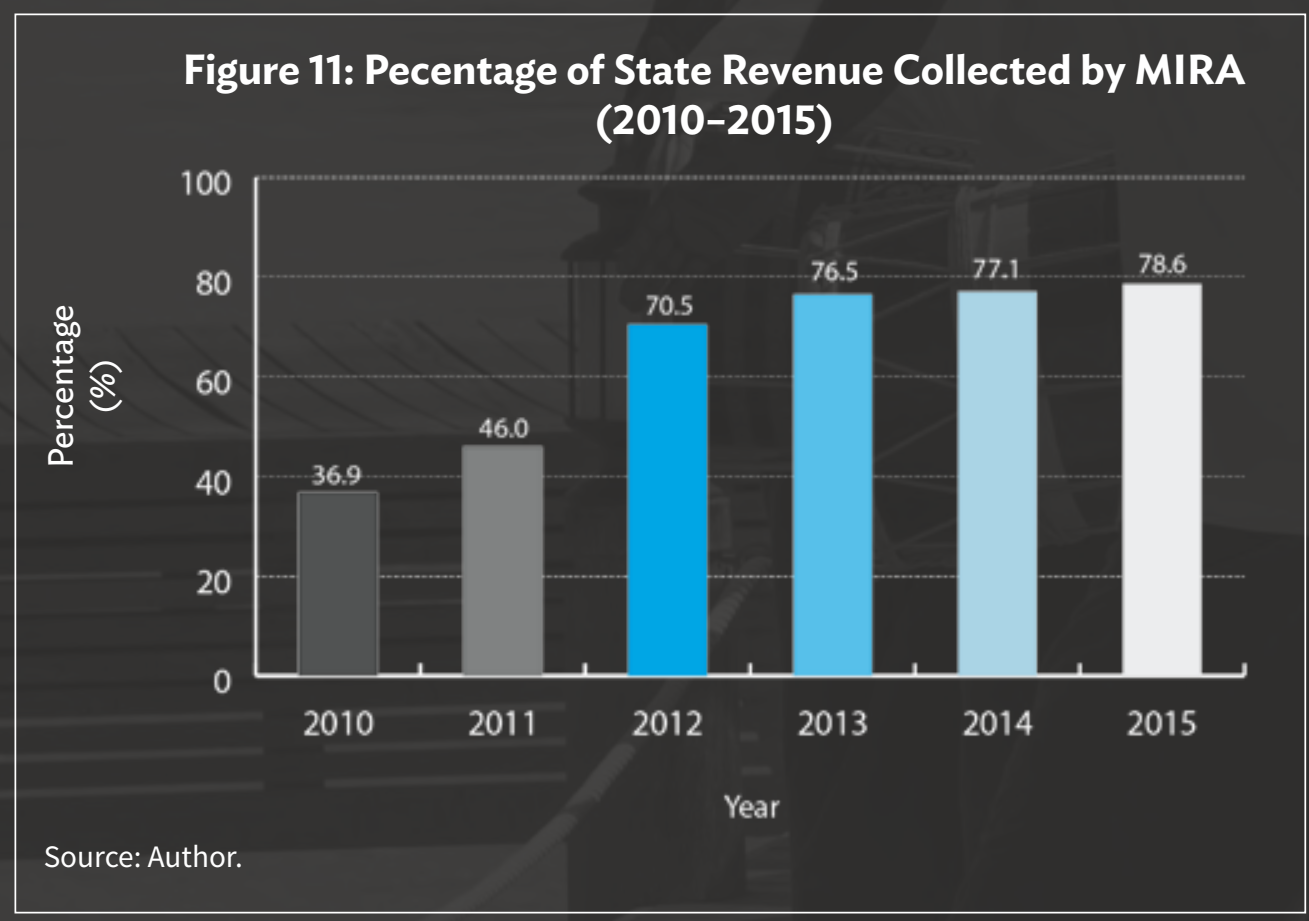




\section{TAX-GROSS DOMESTIC PRODUCT RATIO}

There was also a commensurate increase in the taxgross domestic product (GDP) ratio, the common measure of the proportion of a country's total output (or income) represented by government tax revenue.
After the tax reforms, Maldives' tax-GDP ratio more than doubled from $9.8 \%$ in 2010 to $25.2 \%$ in $2015 .{ }^{1}$ It is projected to increase to $28 \%$ in 2016.

Figure 12: Tax-Gross Domestic Product Ratios (2010-2016)

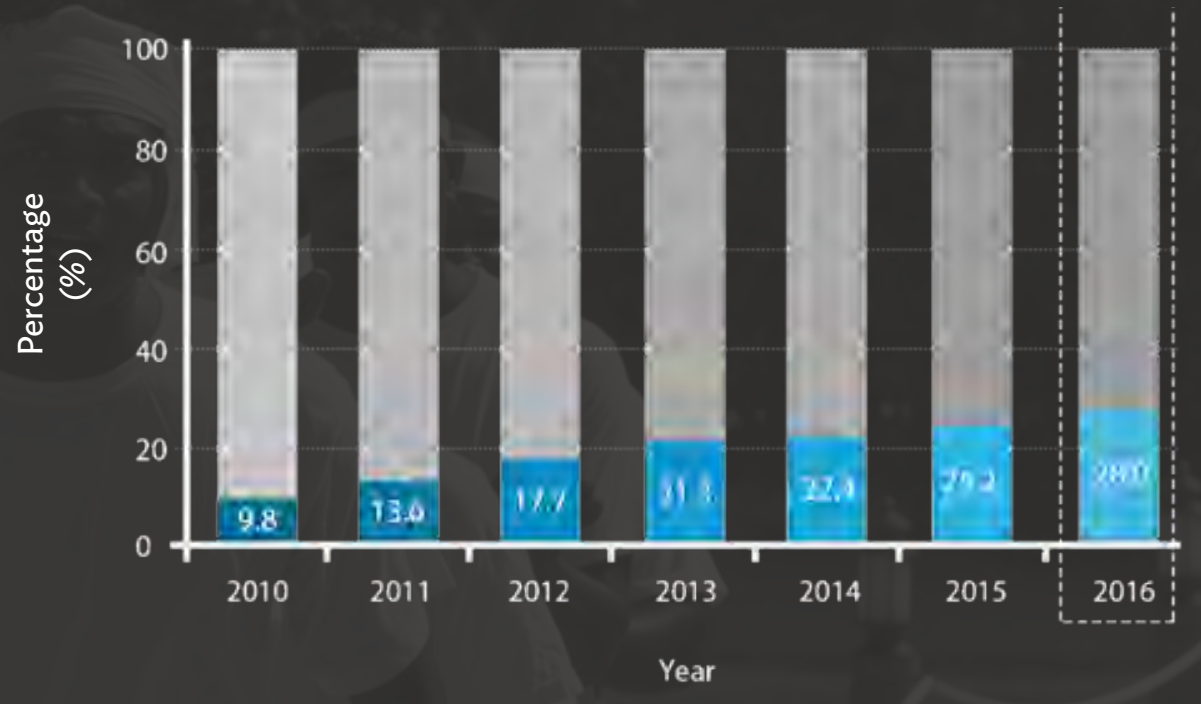

Expected

Source: Author.

Excluding resort lease rents. 


\section{COMPOSITION OF TOTAL GOVERNMENT REVENUE}

The contribution of various revenue types also changed dramatically after the tax reforms were introduced. Figure 13 illustrates that $88 \%$ of all government revenue in 2000 was sourced from import duties (62\%) and tourism tax (26\%). That dependency, however, had fallen markedly by 2011.

In 2011, although import duties still accounted for $52 \%$ of total government revenue, Figure 14 demonstrates that the new taxes (Tourism Goods and Services Tax [T-GST], Goods and Services Tax [GST], and Business Profit Tax [BPT]) were making an impact-although BPT and the general sector GST had not yet been operational for a full year. ${ }^{2}$ Together the new taxes accounted for just under $20 \%$ of total government revenue.

The full impact of the tax reform measures was evident by 2014, when nearly two-thirds of government revenue was attributable to GST and BPT. As Figure 15 illustrates, dependence on import duties had fallen to $16 \%$ and tourism tax to $8 \%$, the latter now extinguished altogether. This diversification of the revenue base has spread the tax burden, with a focus on consumption expenditure, and reduced costs of production through the reduction in import duties.

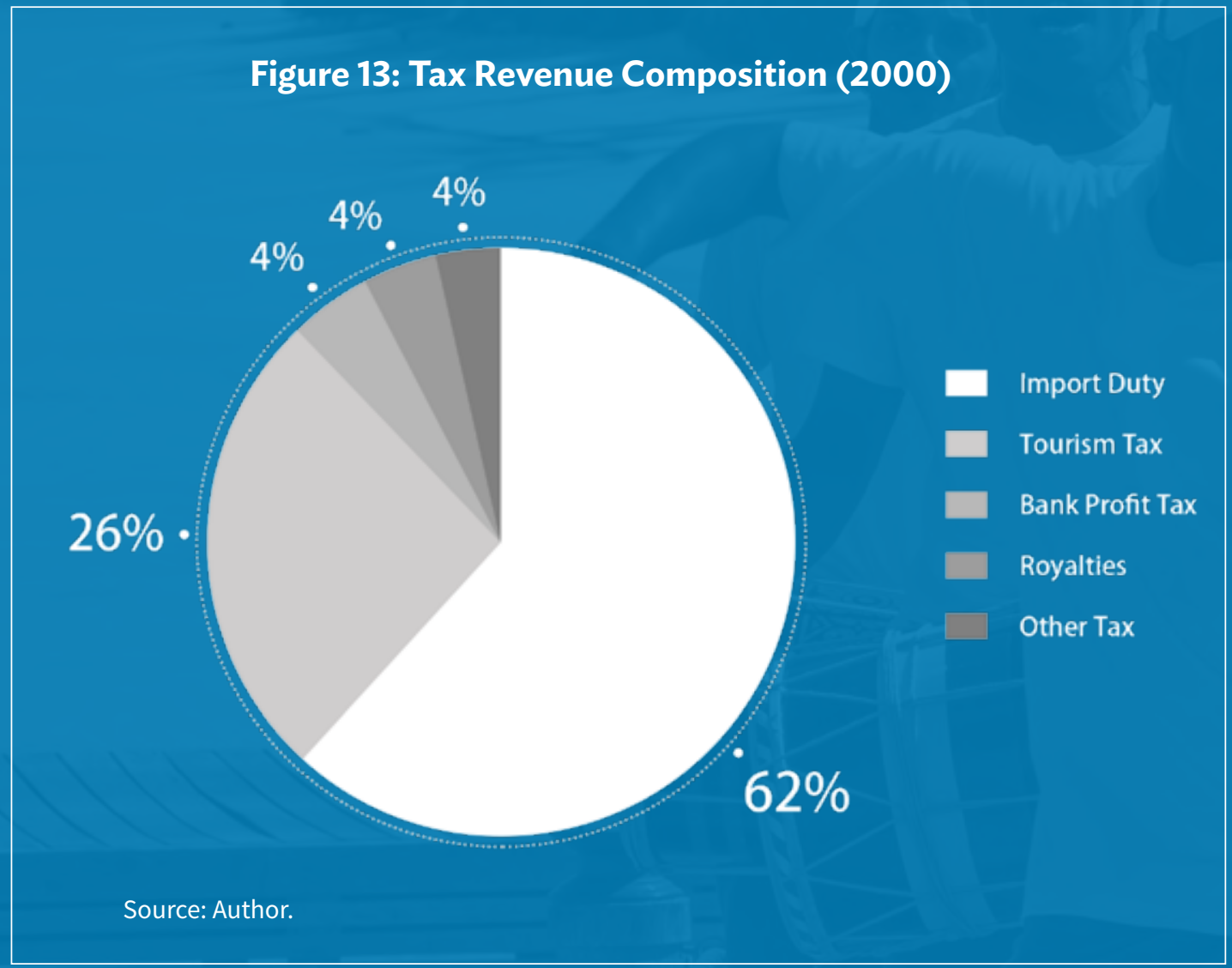

2 Collection of BPT did not take full effect until 2012. 


\section{Figure 14: Tax Revenue Composition (2011)}
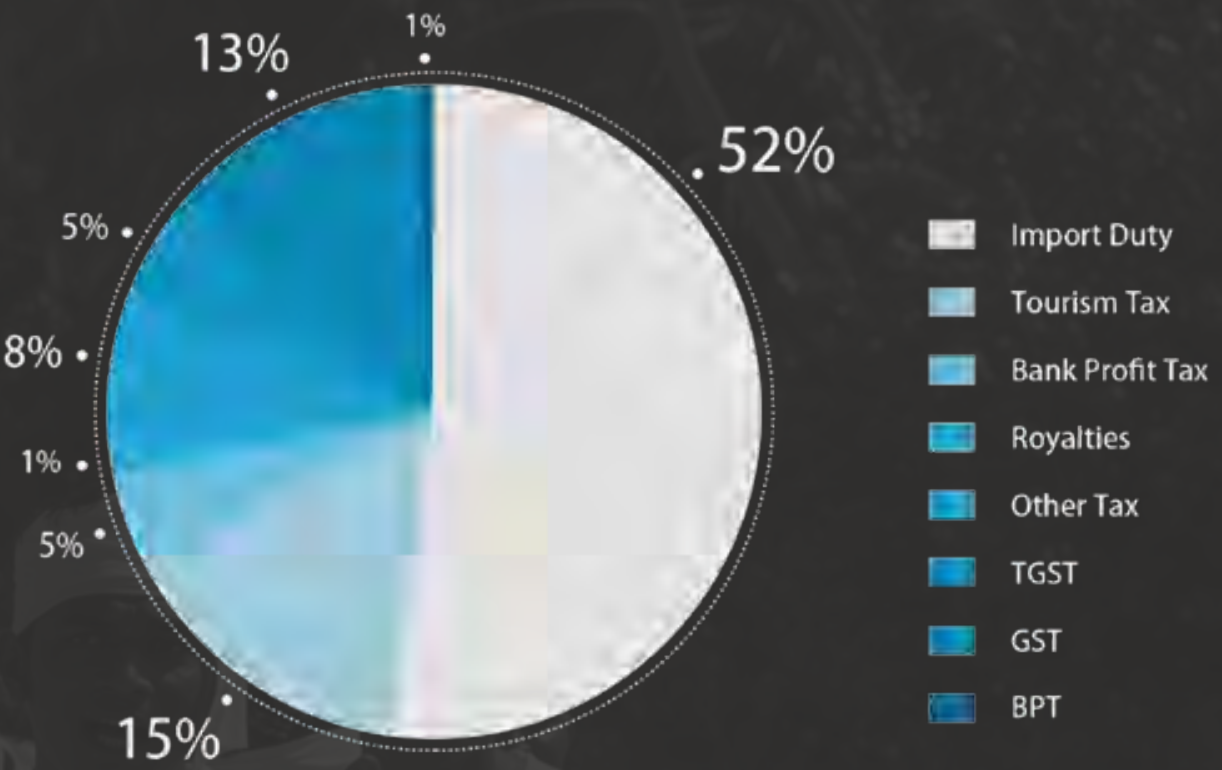

BPT $=$ Business Profit Tax, GST = Goods and Services Tax, T-GST $=$ Tourism Goods and Services Tax . Source: Author.

Figure 15: Tax Revenue Composition (2014)

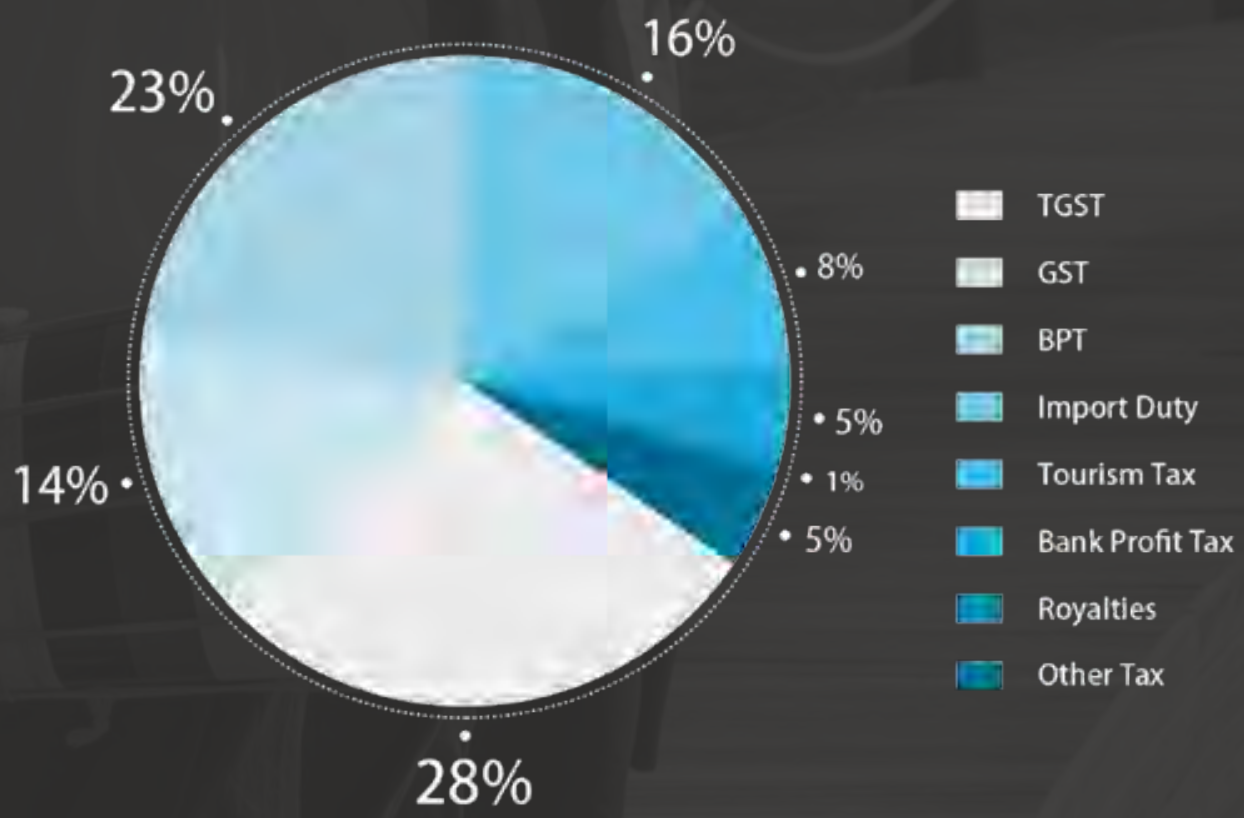

BPT $=$ Business Profit Tax, GST $=$ Goods and Services Tax, T-GST $=$ Tourism Goods and Services Tax. Source: Author. 


\section{COMPOSITION OF REVENUE COLLECTED BY MALDIVES INLAND REVENUE AUTHORITY}

Table 7 shows the contribution of each revenue type collected by MIRA. In 2010, by far the main contributor was tourism land lease rents (46\%), followed at a distance by tourism tax (23\%) and bank profit tax (8\%). The new tax measures show how that position dramatically changed. By 2015 , GST was the main contributor, accounting for slightly over $46 \%$ of all government revenue collected by MIRA, with BPT (including Withholding Tax [WHT]) contributing just over $20 \%$. However, although diversification of revenue sources was one objective of the tax reforms, two-thirds of the GST collected in 2015 still came from the tourism sector.
For the first time, Maldives recorded more than 1 million tourist arrivals in 2013. Growth in that sector carried through to a boost in tourism GST, tourism tax, and the airport service charge. Furthermore, spending by the increased number of tourists flowed through to increased GST receipts in the general sector. The tourism sector rate of GST, which increased from $6 \%$ to $8 \%$ on 1 January 2013 and again to $12 \%$ on 1 November 2014 , also contributed to the increased collection of tourism GST.

\section{Table 7: Revenue Collected by Maldives Inland Revenue Authority, 2010-2015 (Rf million)}

\begin{tabular}{|c|c|c|c|c|c|c|}
\hline \multirow[b]{2}{*}{ Revenue Source } & \multicolumn{6}{|c|}{ Year ended 31 December } \\
\hline & 2010 & 2011 & 2012 & 2013 & 2014 & 2015 \\
\hline BPT (excluding WHT) & - & 0.4 & $1,157.1$ & $1,586.7$ & $2,075.2$ & $2,246.2$ \\
\hline WHT & - & 34.7 & 244.0 & 295.1 & 400.1 & 428.4 \\
\hline GST - tourism & - & 836.5 & $1,566.4$ & $2,451.2$ & $3,027.1$ & $4,147.3$ \\
\hline GST - nontourism & - & 86.8 & $1,005.7$ & $1,203.5$ & $1,515.1$ & $1,907.2$ \\
\hline Airport service charge & 35.5 & 337.5 & 299.9 & 350.3 & 432.0 & 496.7 \\
\hline Bank profit tax & 203.2 & 229.9 & 313.2 & 355.0 & 482.2 & 512.7 \\
\hline Tourism tax & 549.4 & 750.7 & 802.9 & 860.1 & 804.7 & 0.6 \\
\hline Tourism land lease rental & $1,100.4$ & $1,202.5$ & $1,049.8$ & $1,068.8$ & $1,156.2$ & $1,199.2$ \\
\hline $\begin{array}{l}\text { Lease period extension } \\
\text { fee }\end{array}$ & 19.1 & 511.3 & 168.7 & - & 789.4 & $1,095.9$ \\
\hline Land sales tax & 10.8 & 7.3 & 16.6 & 20.7 & 28.5 & 29.1 \\
\hline Other nontax revenue $\mathrm{e}^{\mathrm{a}}$ & 494.3 & 562.6 & 527.9 & 801.7 & 786.9 & 992.6 \\
\hline Total & $2,412.7$ & $4,560.2$ & $7,152.1$ & $8,993.1$ & $11,497.4$ & $13,056.0$ \\
\hline
\end{tabular}

BPT = Business Profit Tax, GST = Goods and Services Tax, WHT = Withholding Tax .

a Other nontax revenue, collected by MIRA, includes business permits, fines, nontourism property income, proceeds from sale of assets, resident permits, royalties, revenue stamp sales, and vehicle and vessel fees.

Source: Author. 


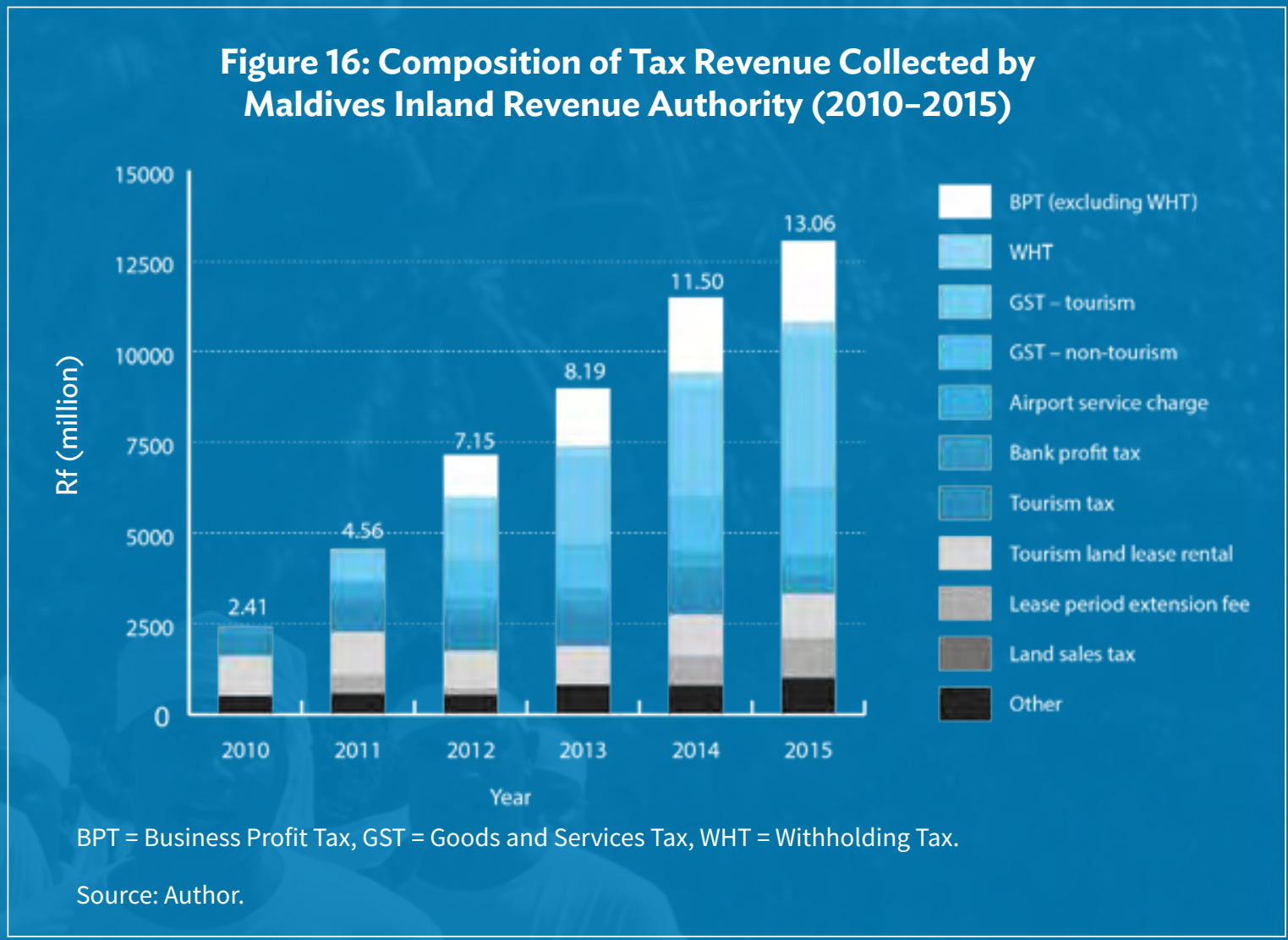

General economic and business growth in Maldives during 2013-2015 contributed to the increase in BPT and general sector GST collections. These increases also suggest that BPT and general sector GST taxpayers became increasingly aware of their tax obligations, thus increasing the level of taxpayer compliance.

Nonrealization of substantial lease period extension fees (applicable to resort islands) was attributed to a change in government policy, which froze the collection of such fees in 2012.

Until 1 October 2014, an airport service charge (ASC) of $\$ 12$ was imposed on each Maldivian aged over 2 years departing Maldives by air. ${ }^{3}$ An ASC of $\$ 18.50$ was imposed on each foreigner who departed Maldives by air. After a failed attempt in May 2013 to increase the charge by $62 \%$, the government subsequently obtained Parliament's approval to increase the charge on foreigners, who are the main contributors of ASC, by $35 \%$ to $\$ 25$.

The government also attempted to increase the tourism GST rate from $8 \%$ to $15 \%$, with effect from 1 June 2013. The proposition failed to achieve adequate parliamentary support and the GST
Amendment Bill, which was to empower the new rate, was withdrawn in June 2013.

Largely as a result of ballooning government expenditure, the budget deficit continually widened during the posttax reform period. Consequently, the government announced a policy reversal on import duties and increased the general GST rate to $6 \%$ from 1 January 2014 and the tourism GST rate beyond the increase to $8 \%$ planned for 2013 to $12 \%$ with effect from 1 November 2014.

The performance of WHT is worthy of mention since, after fervent lobbying by the tourism sector in particular, in August 2011 the President undertook to abolish WHT. The intention of the government prior to February 2012 was to replace the BPT Act by CPT and PIT legislation. Parliament in April 2012 passed the CPT Bill, which imposed a WHT rate of $0 \%$. However, the President in the post-February 2012 government declined to ratify the law and returned it to Parliament for reconsideration, but it never reemerged. Abolition of WHT at this stage of the Maldives' tax reform experience is irrational, particularly in the absence of an income tax and the government's dire need for tax revenue.

3 The ASC (formerly "airport tax") was transferred from the airport authority to central government accounts in November 2009. 


\section{Figure 17: Percentage Composition of Revenue Collected by Maldives Inland Revenue Authority in 2015}

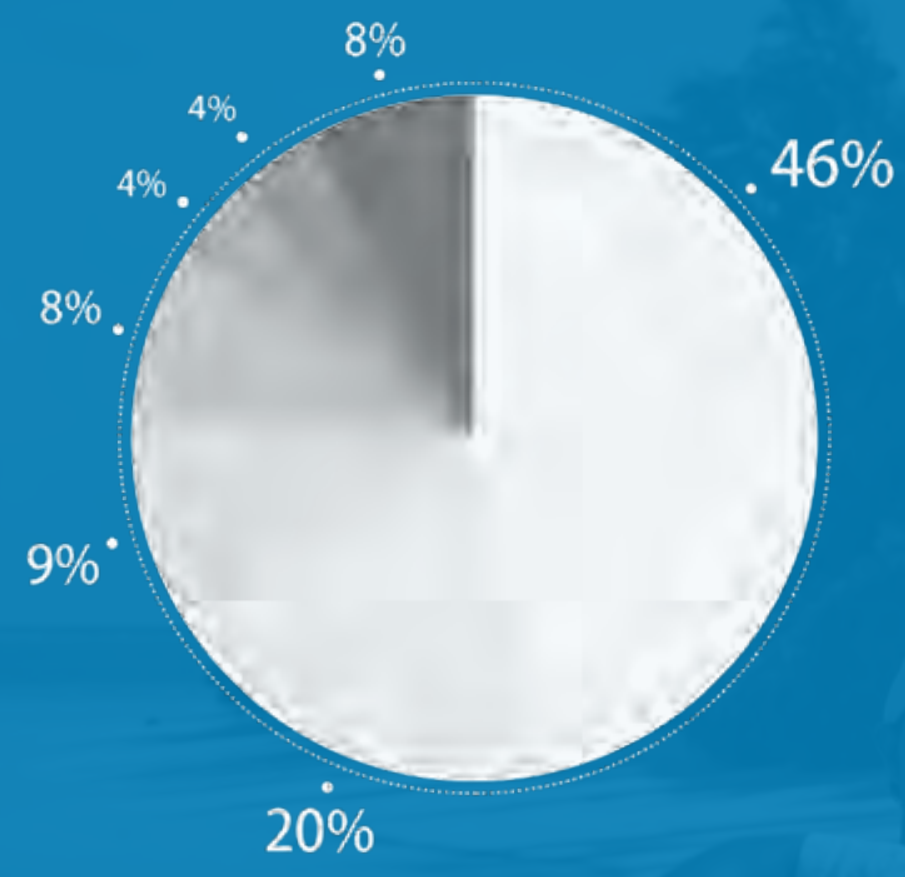

GST

BPT

E. Tourism Land Rent

Lease Period Extension Fees

Bank Profit Tax

Airport Service Charge

Other

BPT = Business Profit Tax, GST = Goods and Services Tax.

Source: Author.

\section{TAX RECEIPTS}

Payments of tourism GST, tourism land rent, tourism tax, and the airport service charge are required to be made in US dollars. Figure 18 shows how the tax receipts have grown in 2010-2015. The 69\% increase in US dollar tax receipts in 2011 is attributable to the introduction of T-GST (and subsequently tourism GST). The $27 \%$ increase in $2013,44 \%$ in 2014 , and $15 \%$ in 2015 came about because of:

(i) the increased tourism GST rates (a 33\% increase in the rate in 2013 and a $50 \%$ increase in the rate in 2014)

(ii) the generally buoyant tourism market in 2013 and 2014 , evidenced in particular by a $17.4 \%$ increase in tourist arrivals in 2013 and a 7.1\% increase in 2014; and (iii) an 11\% growth in nominal GDP in 2013 and $9.7 \%$ in 2014.

Although the majority of revenue collected by MIRA is in US dollars, as a percentage of total receipts, it has fallen from $82.4 \%$ in 2011 to $61 \%$ in 2015 because of

(i) the greater contribution now made by Maldivian businesses and consumers who pay tax in Maldivian rufiyaa, and

(ii) the requirement that all BPT be paid in Maldivian rufiyaa. 
Figure 18: Revenue Receipts (in US Dollars, 2010-2015)

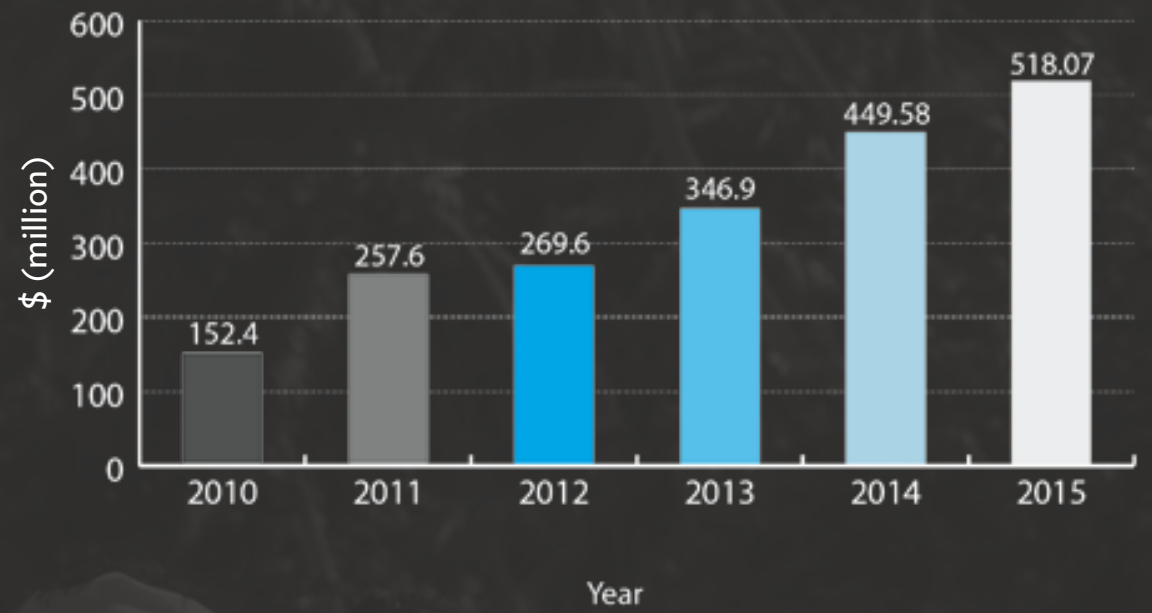

Source: Author.

Figure 19: Currency Composition of Tax Receipts

(2010-2015)

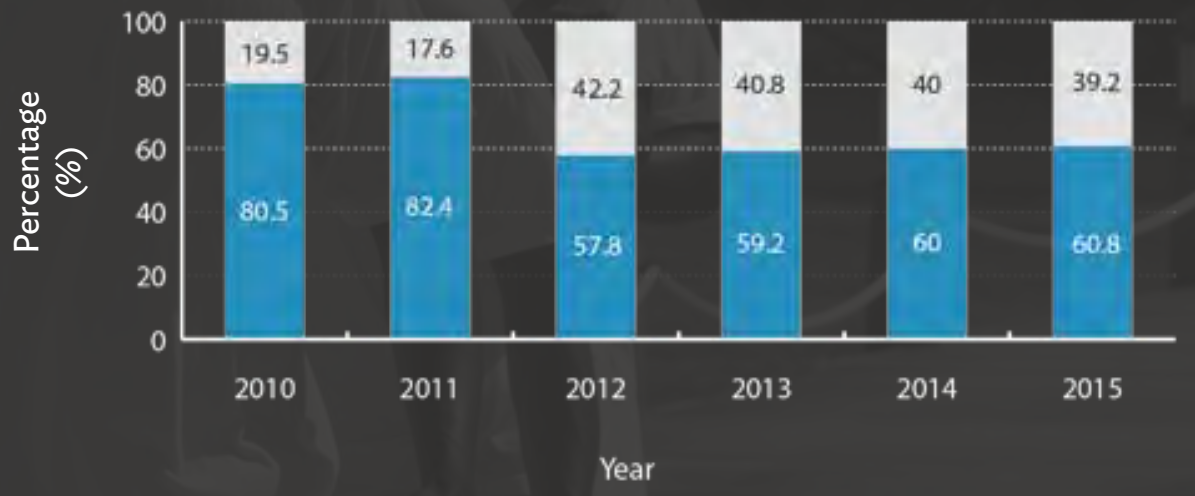





\section{STAFF}

Success is not measured by tax revenue receipts alone. Other $\operatorname{tax}$ administration outputs, which ultimately drive the increase in tax revenue, can also be measured and assessed. However, like revenue collection, those outputs are generated by MIRA staff. Before looking at tax administration outputs, it is worth seeing how staff numbers and staff composition changed from 2010 to 2015.

Figure 20 shows that MIRA's staff complement increased at an annual compound rate of nearly 33\% from 59 staff members in 2010 to 244 in 2015.
Table 8 shows that from 2011 to 2014 the average age of the staff fell from 27 to 25 years, indicating a loss of older, more experienced staff and the recruitment of less experienced staff, which necessitates greater investment in staff training. The decline points to a need to focus on investment in staff tertiary education through scholarships and leaves of absence in order to retain experienced staff.

The ratio of graduates to nongraduates has fallen marginally to $1: 1$ since 2012 , which correlates with the fall in average age. The male-female staff ratio is close to equilibrium.

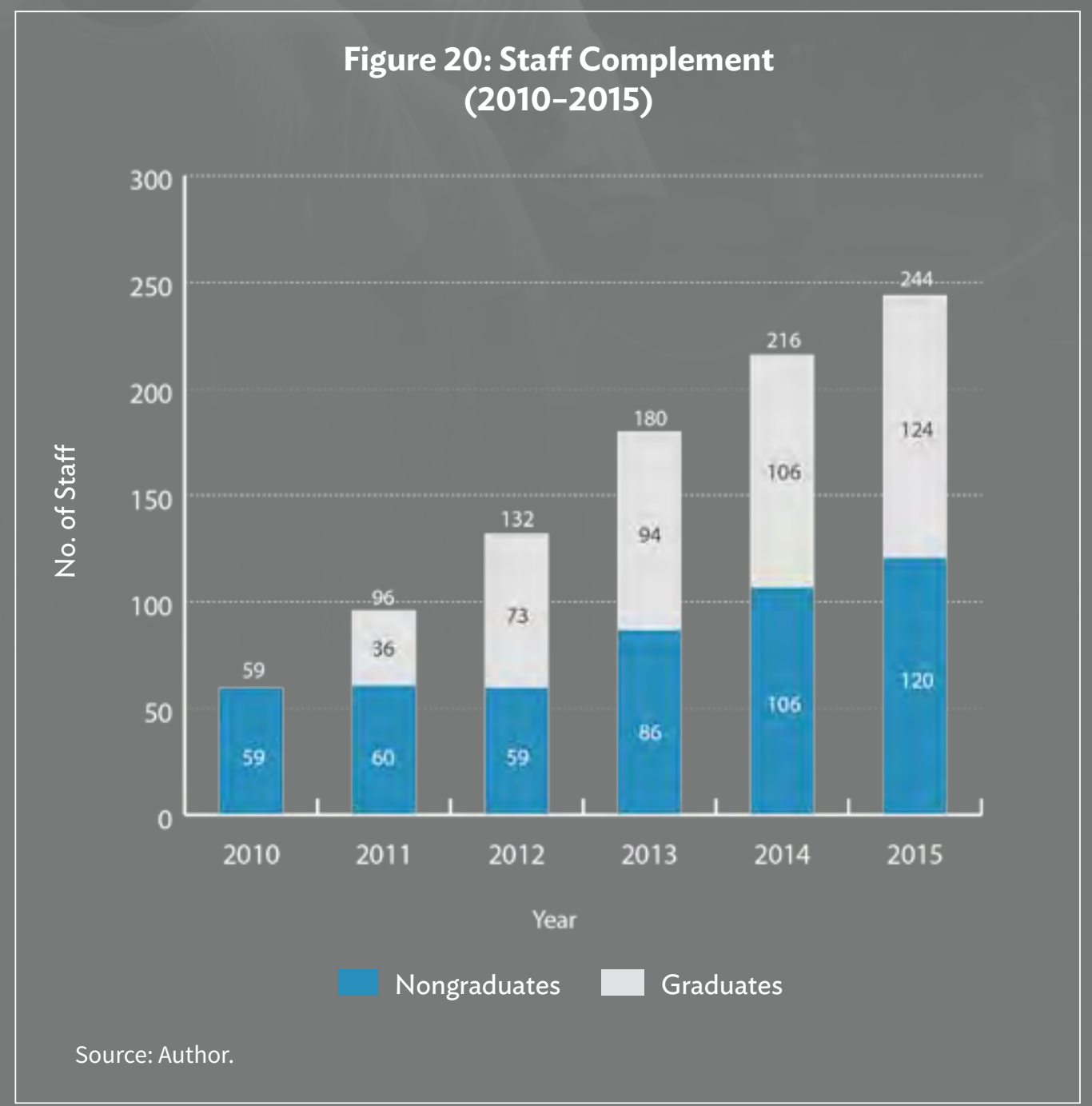


66 We are facing continuous change on a range of things. If something is not working as planned, we change it. Young people are not afraid of change; they like change. We give them training, promotions, and incentives to show staff that there is a future for them. Under our internal promotion criteria, we implore staff to take up new positions. That retains key staff. We can do this because we are an independent institution, which is not tied to civil service regulations. 99

Yazeed Mohamed Commissioner General of Taxation

Table 8: Maldives Inland Revenue Authority Staff Profile (2011-2015)

$\begin{array}{cccc}\text { Year } & \text { \% Graduates } & \text { Average Age } & \text { Male:Female } \\ 2011 & 37.5 & 27 & 48: 52 \\ 2012 & 55 & 27 & 48: 52 \\ 2013 & 52 & 26 & 53: 47 \\ 2014 & 51 & 25 & 51: 49 \\ 2015 & 51 & 25 & 52: 48\end{array}$

Source: Author.

66 We have developed a proper working culture at MIRA. Staff have better incentives than in the civil service, including wages and higher education scholarships. Relatives push job seekers to apply for jobs at MIRA. 99

Hassan Zareer Deputy Commissioner General of Taxation 


\section{REGISTRATION OF TAXPAYERS}

One of the most significant tax administration performance outputs is the level of taxpayer registration, which indicates the degree to which people and companies, which are required to pay tax, are brought within the tax net.
As demonstrated by Figure 21, both business registrations and GST registrations have trended upward since the introduction of BPT and GST, as a consequence of increasing business activity in a growing economy and rigorous policing by MIRA.

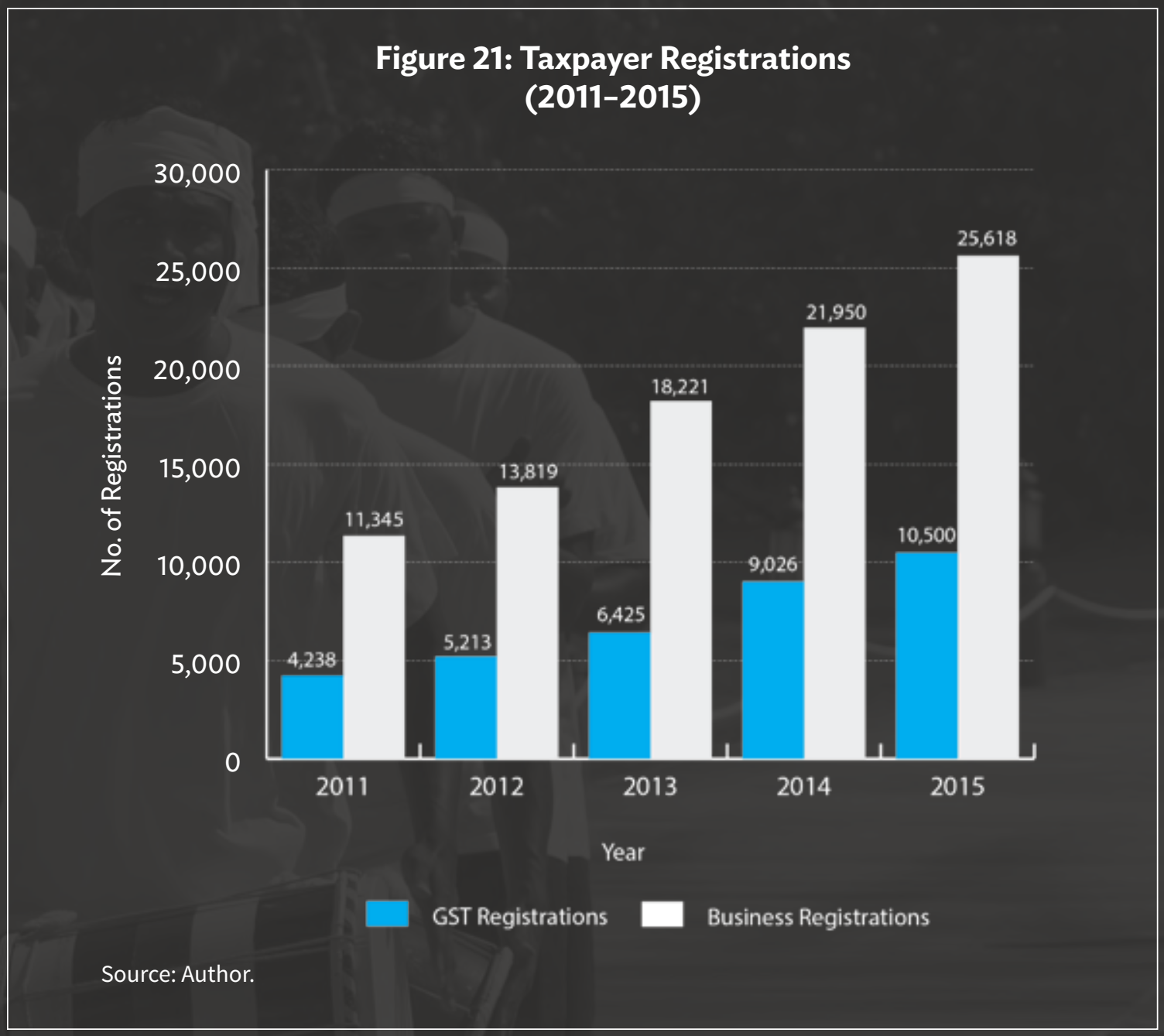

\section{Some people who would be liable to register for GST have not registered and still carry on the business. The tax law should require all businesses to register with MIRA. 99}

Anwarusalam Aboobakuru

Chief Operating Officer, Biyalanco, Kulhudhuffushi 
From 2012, the majority of MIRA's staff (regardless of their role) was involved in compliance checks on a dedicated Saturday in each month. This involved staff visiting business premises to determine whether the business operator was complying with its tax obligations. If not, follow-up action by the Compliance Department ensued.
Figure 22 shows that compliance visits began in earnest in 2012 and more than doubled in 2013, after which their frequency has leveled out.

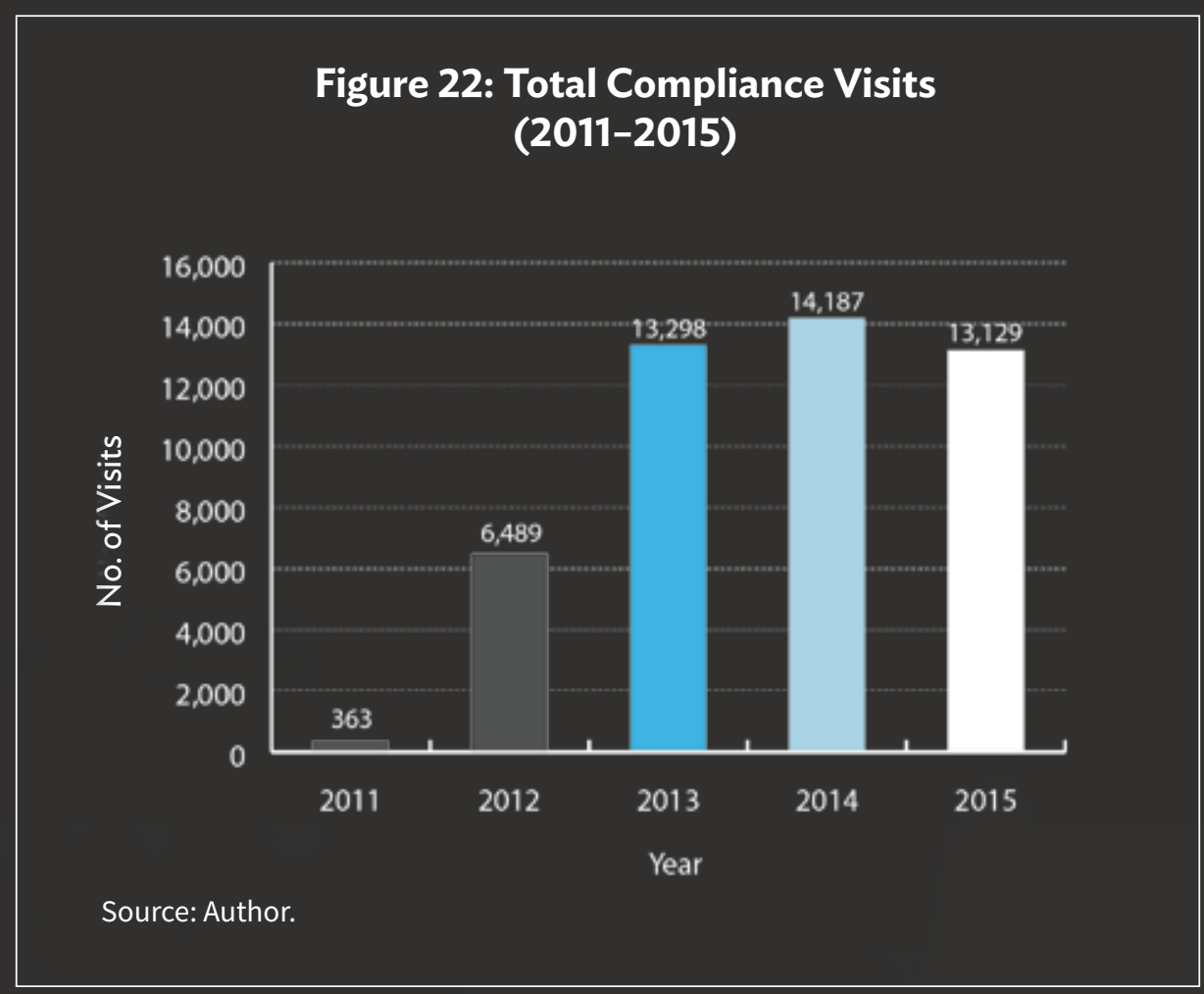

The names of taxpayers who persist in noncompliance with the GST laws are published on MIRA's website, in accordance with MIRA's Policy on Disclosure of Noncompliant GST Registered Persons. In 2015, 849 names were published under this policy.

MIRA introduced a skip-tracing policy in 2012. When a taxpayer fails to respond to a second demand from MIRA for payment of outstanding tax, MIRA directs government departments to desist in providing services to the taxpayer. This applied in 3,296 cases in 2014. ${ }^{4}$ Where that action fails to resolve the tax matter, MIRA requires, through the Maldives Monetary Authority, that commercial banks freeze the taxpayer's bank accounts. This action was taken on 132 taxpayers in 2015. Failing these measures, court proceedings are pursued to recover the outstanding tax.

\footnotetext{
4 Latest figures available at 31 December 2015.
} 


\section{AUDIT}

Like compliance activities, tax audits became more prevalent in 2012. During 2011, audits were primarily T-GST audits and novice auditors were undergoing extensive training. Figure 23 shows a 392\% increase in audits in 2012, as a result of greater availability of trained auditors and the first full year of filing general
GST returns and the first filing of BPT returns. Audit activity intensified with a 155\% increase in 2013 . The decline in the number of audits carried out in 2014 and 2015 reflects a more targeted audit approach with increased concentration on fewer audits.

66 We need to clarify the law to distinguish tax investigations and tax audits. The 2-year limit to start an audit should be extended to allow more audits of earlier periods. 99

Fathuhulla Jameel

Director General - Audit and Investigation, MIRA (2012-2016) 


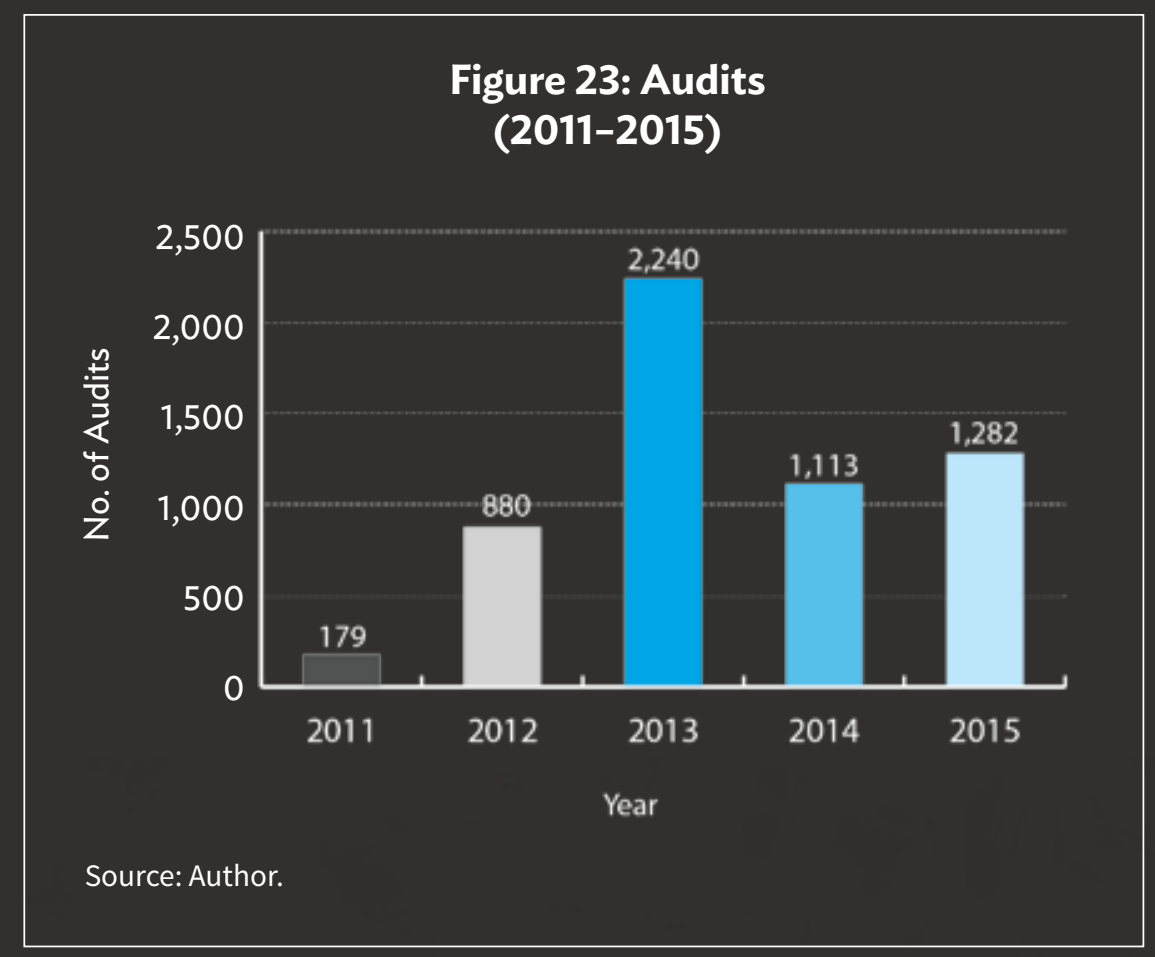

One indicator of success of the audit function is the measure of additional taxes assessed as a result of the audits. ${ }^{5}$ Figure 24 demonstrates that MIRA's audit activities during 2011-2015 paid off. The additional tax assessed correlates positively with the number of audits undertaken each year. Over the entire period, an additional Rf956 million of tax was assessed as a consequence of the audits undertaken.

Figure 24: Additional Taxes Assessed from Audits (2011-2015)

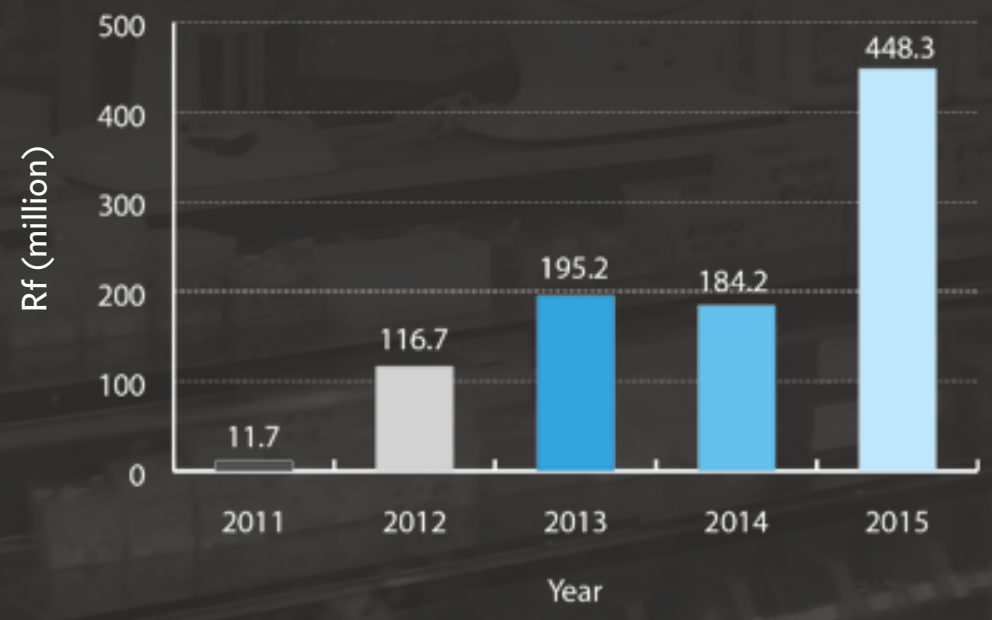

Source: Author.

5 Provided that the assessments survive taxpayer challenge and the assessed amounts of tax are actually collected. 


\section{ENFORCEMENT}

Additional taxes are also collected by the Enforcement Department from delinquent taxpayers who fail to meet their tax payment obligations. Figure 25 shows that for the 2011-2015 tax years, a total of nearly $\mathrm{Rf} 2.5$ billion was recovered by enforcement action.

\section{OBJECTIONS}

One consequence of tax assessments issued by MIRA, either as an outcome of an audit or to tax defaulters, is that taxpayers may challenge the amount of tax assessed. That did indeed happen in a total of 261 cases over the 2011-2015 tax years. As Figure 26 illustrates, the average number of objections per year since 2012 has been approximately 60 . This means that, on average, objections have arisen in just over $6 \%$ of audits carried out.

\section{Figure 25: Total Amount of Recoveries from Enforcement Action (2011-2015)}

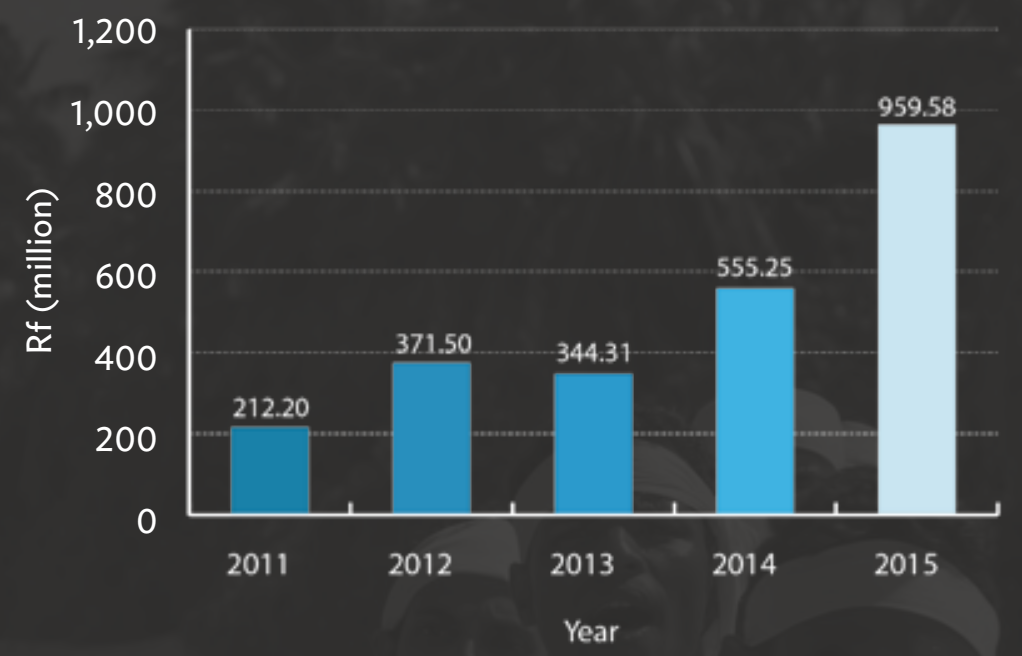

Source: Author.

\section{Figure 26: Objections Received and Objections as Percentage of Audits (2011-2015)}

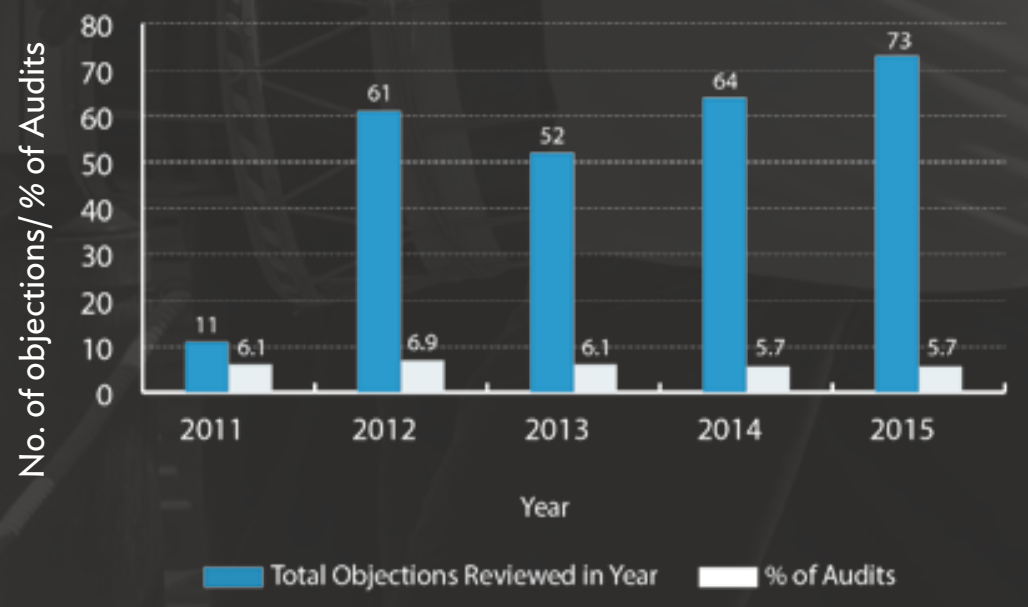

Source: Author. 


\section{LITIGATION}

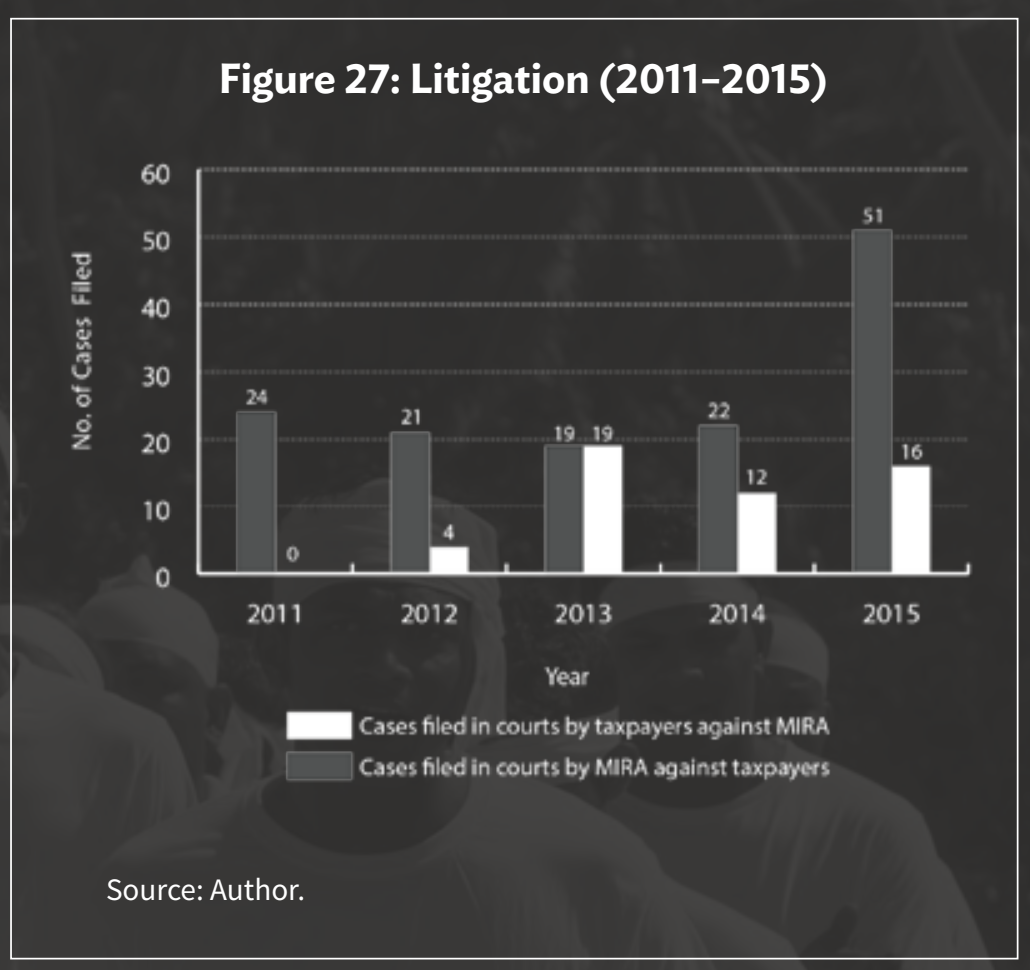

\section{TAX RULINGS}

As explained in Chapter 4, MIRA issues tax rulings to clarify for taxpayers the way that it applies the tax statutes. By the end of 2015, MIRA had issued a total of 93 rulings: 39 GST rulings (including 2 T-GST rulings), 51 on BPT matters, and 3 on other matters (registration of individuals, submission of documents during the objection process, and mandatory online filing and payment for large taxpayers).
It is one thing for a taxpayer to lodge an objection to an assessment; it is quite another for the objection to be upheld either by MIRA (which is relatively infrequent) or at TAT or court. Litigation also frequently results from taxpayers challenging MIRA's tax recovery enforcement actions.

As demonstrated in Figure 27, the number of cases filed in the courts by MIRA against taxpayers were reasonably constant during 2011-2014, averaging around 20, but increased dramatically in 2015, partly because of an increase in the number of cases passed on for legal action by the Enforcement Department.

The number of cases filed in the courts by taxpayers against MIRA during 2012-2015 has been far lower. It is worth noting that MIRA has generally been successful in most litigation; in particular, no judgments were passed against MIRA in 2014, and only one tax judgment was passed against it in 2015.
Figure 28 illustrates the number and types of rulings issued during the 2011-2015 tax years, with 2012 being a particularly active year, especially since the ramifications of the BPT Act were becoming apparent during the first full year of operation of the BPT regime. 


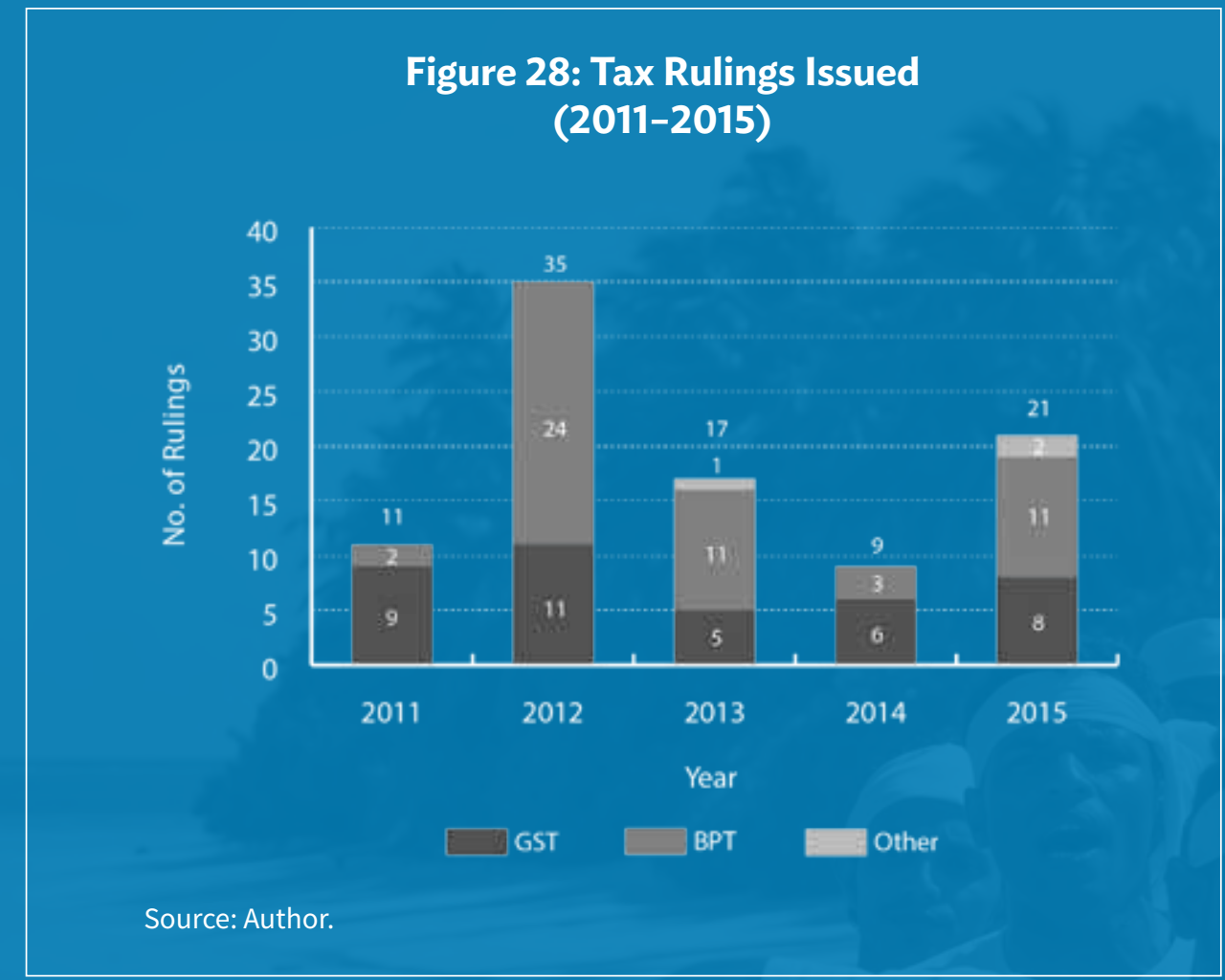

\section{TAXPAYER EDUCATION}

MIRA has been particularly vigilant in promoting public awareness of the new tax regime and taxpayers' compliance obligations. Figures 29 and 30 show that throughout 2011-2015, MIRA delivered a total of 1,149 presentations and workshops to taxpayers, which involved more than 20,000 participants.

Figure 29: Taxpayer Presentations and Workshops (2011-2015)

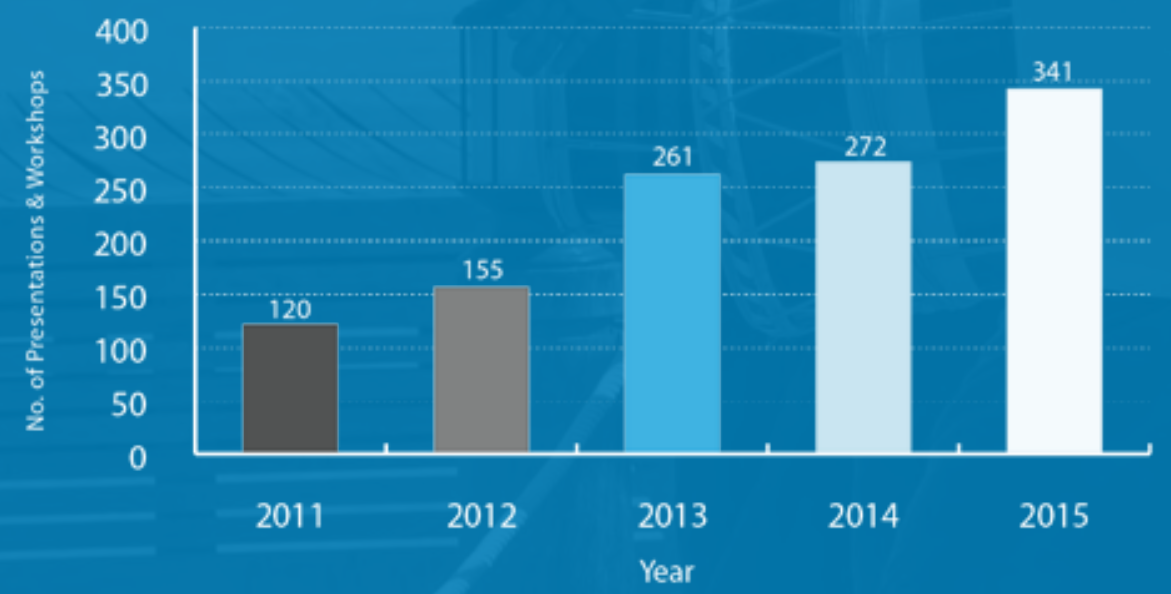

Source: Author. 
66 We want to show the public our presence is still always there so we have public activities. More than 30 staff are trained for this. We have 20-30 radio/TV programs per month. The general public appreciates MIRA, shown by things like comments in newspapers. School kids know about the tax system and MIRA. MIRA's branding color has even been adopted by other organizations. 99

Hassan Zareer

Deputy Commissioner General of Taxation

Figure 30: Participation in Taxpayer Presentations and Workshops (2011-2015)

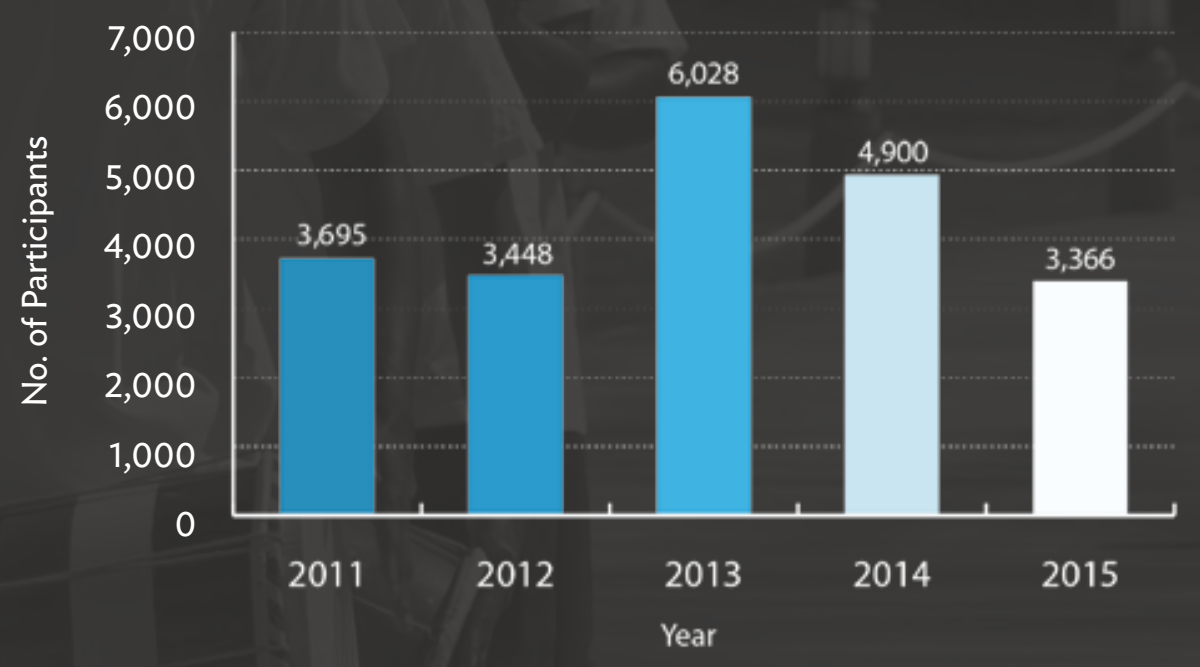

Source: Author. 



\section{TAX ADMINISTRATION EXPENDITURE}

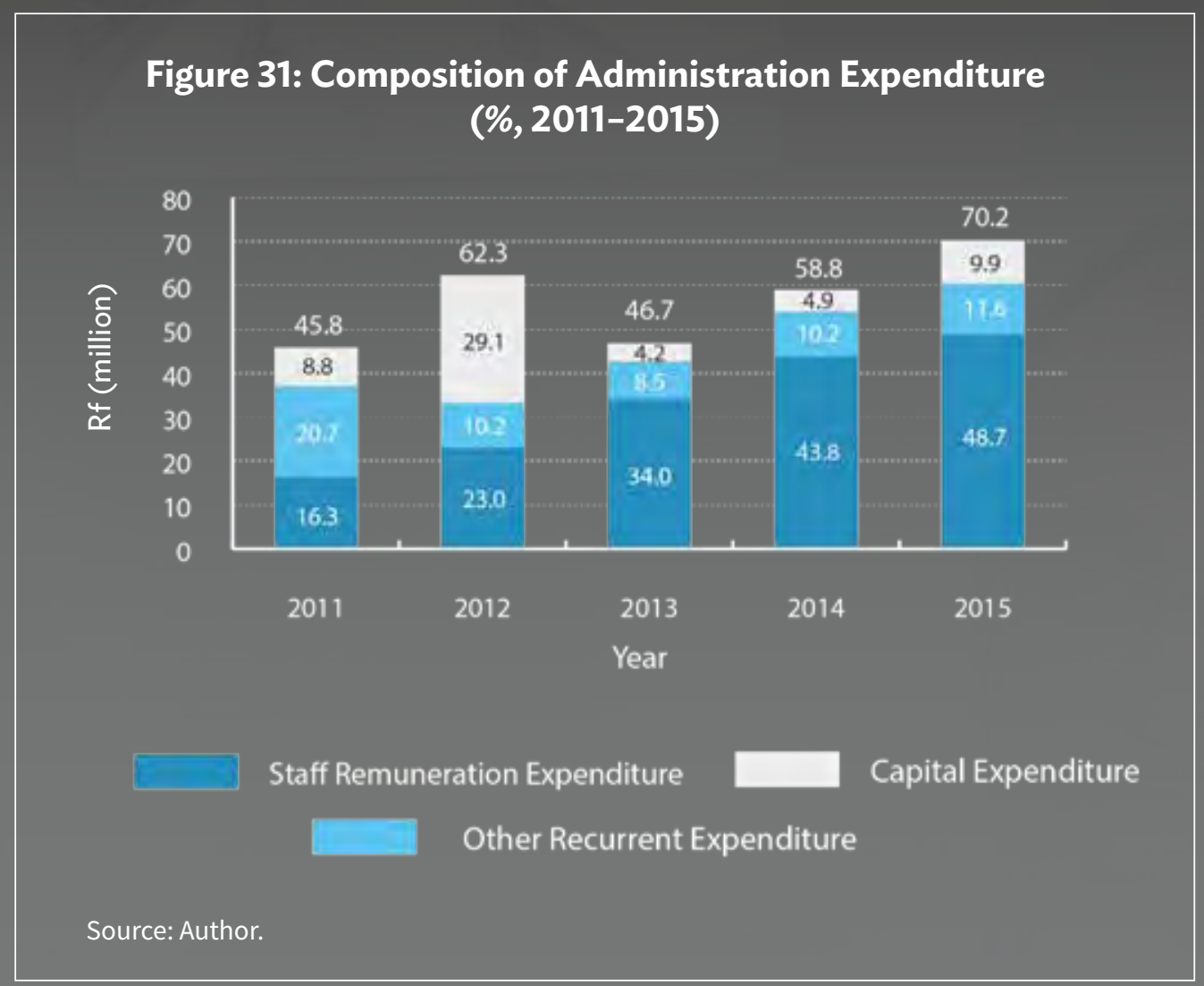

MIRA's total administration expenditure has fluctuated over the 2011-2015 period, largely as a result of varying levels of annual capital expenditure. Figure 31 shows that MIRA's recurrent expenditure has increased at an annual compound rate of $13 \%$ (even taking account of a $10.3 \%$ reduction in 2012). More than $80 \%$ of MIRA's annual recurrent expenditure is now spent on staff salaries, allowances, and pensions. ${ }^{6}$ The annual compound percentage rate of increase in this category of expenditure during 2011-2015 was $31.5 \%$.

As Figure 32 demonstrates, the government derives a very favorable return from its investment in MIRA's operations. Administrative expenditure per rufiyaa collected was 0.8 laari in 2011. In 2012, it increased to
1 laari per rufiyaa collected. The main reason for this increase was capital expenditure on the SAP IT project in 2012, which comprised $39.4 \%$ of the total administrative expenditure for the year. If that expenditure is excluded, expenditure per rufiyaa collected in 2012 is 0.5 laari. MIRA has maintained an expenditure rate of 0.5 laari per rufiyaa collected in 2013 and 2014, and 0.54 laari per rufiyaa collected in 2015.

Overall, these statistics are impressive by any measure for a novice tax administration operating in a developing country, which implemented wide-ranging tax reforms in a remarkably short period of time under substantial pressure. 


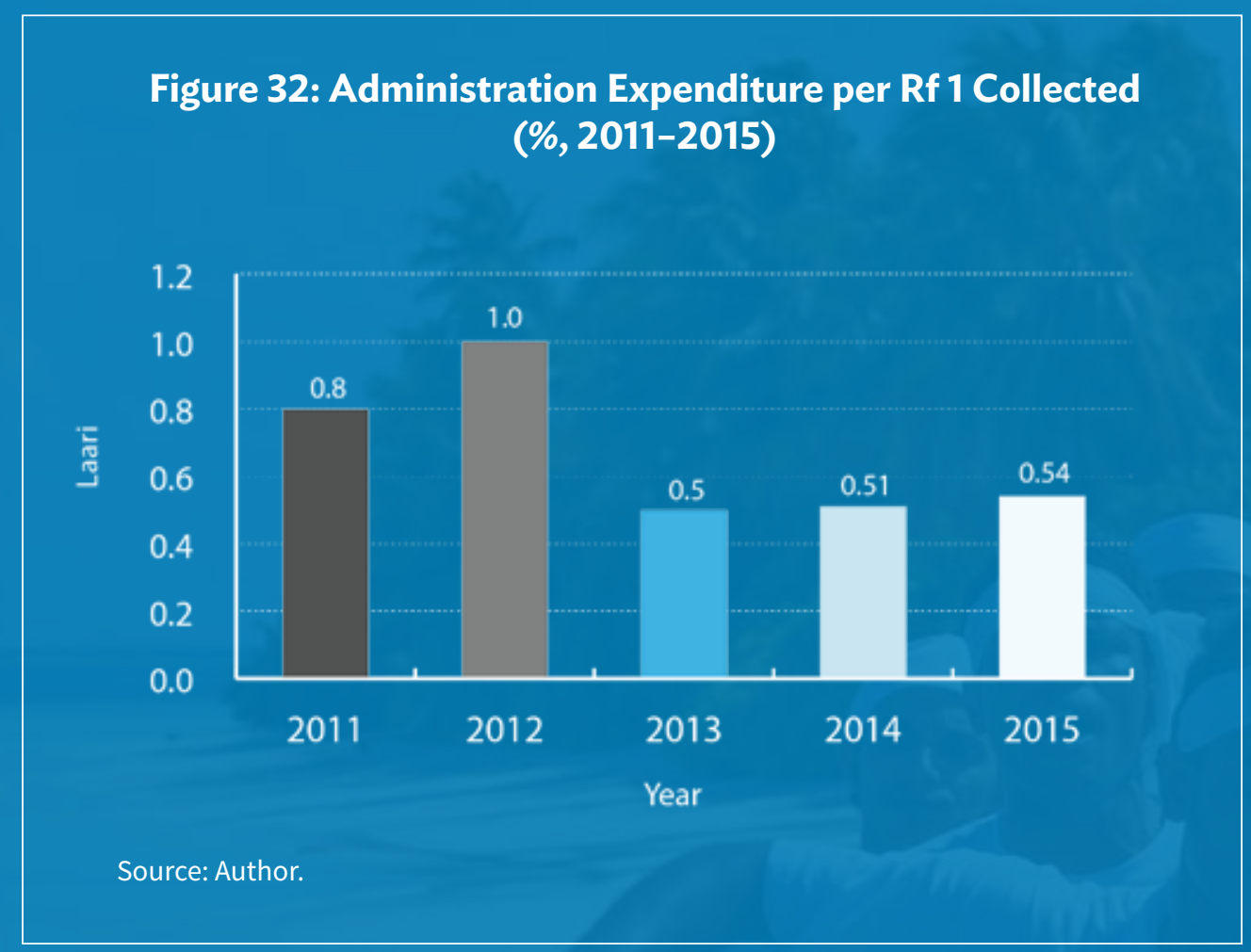

\section{Maldives faces considerable challenges with its} geographical dispersion of population. Taxpayers are dispersed over 200 islands and many hundreds of kilometers of ocean. Communicating with, educating, and auditing businesses outside Male' pose unique challenges. For example, audits outside Male' need to be completed in a campaign fashion, with multiple audits being scheduled for the single visit as the cost and logistical issues in visiting the outer islands for one-off audits are prohibitive. 99 


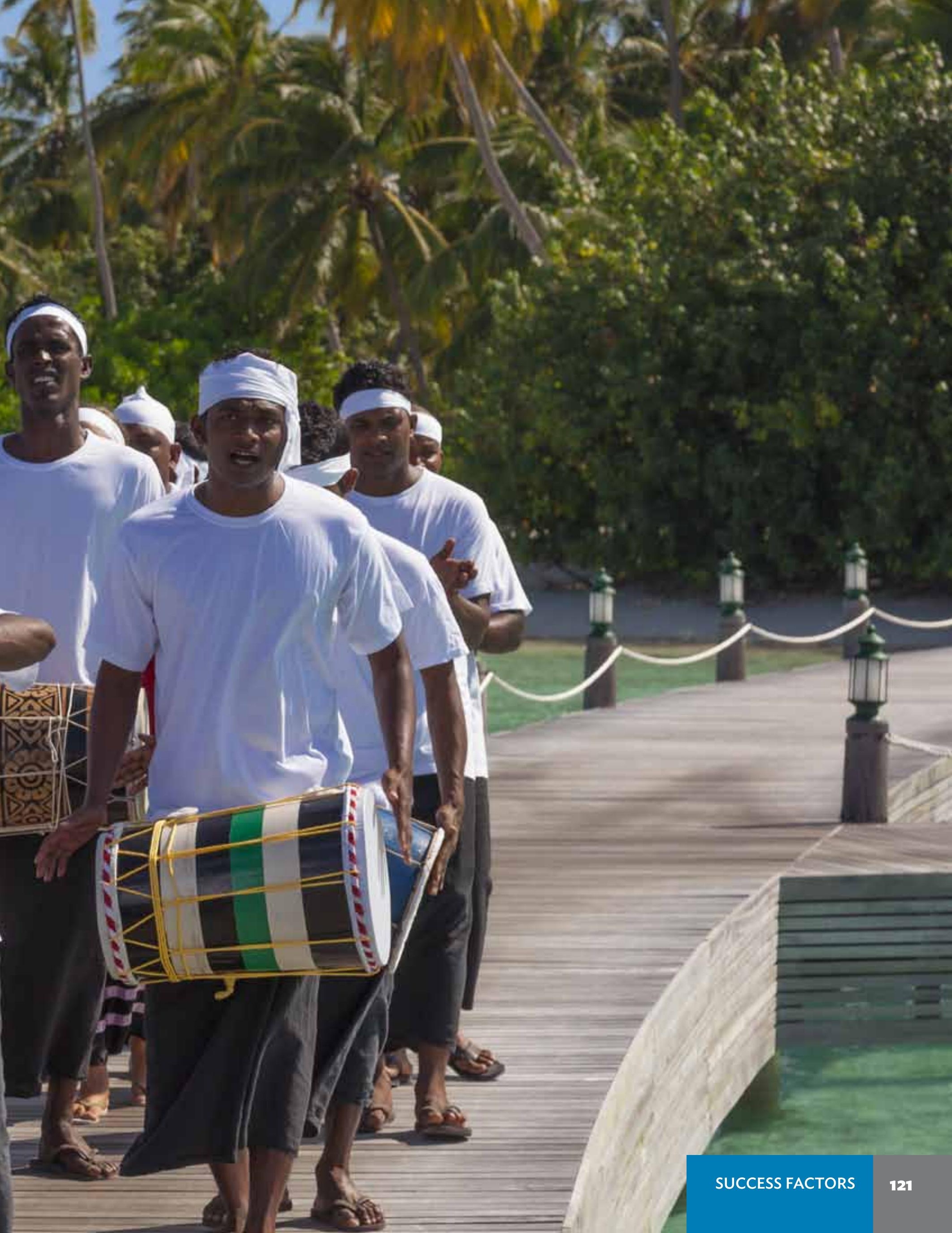




\section{CHAPTER 7}

\section{Maintaining the Impetus}

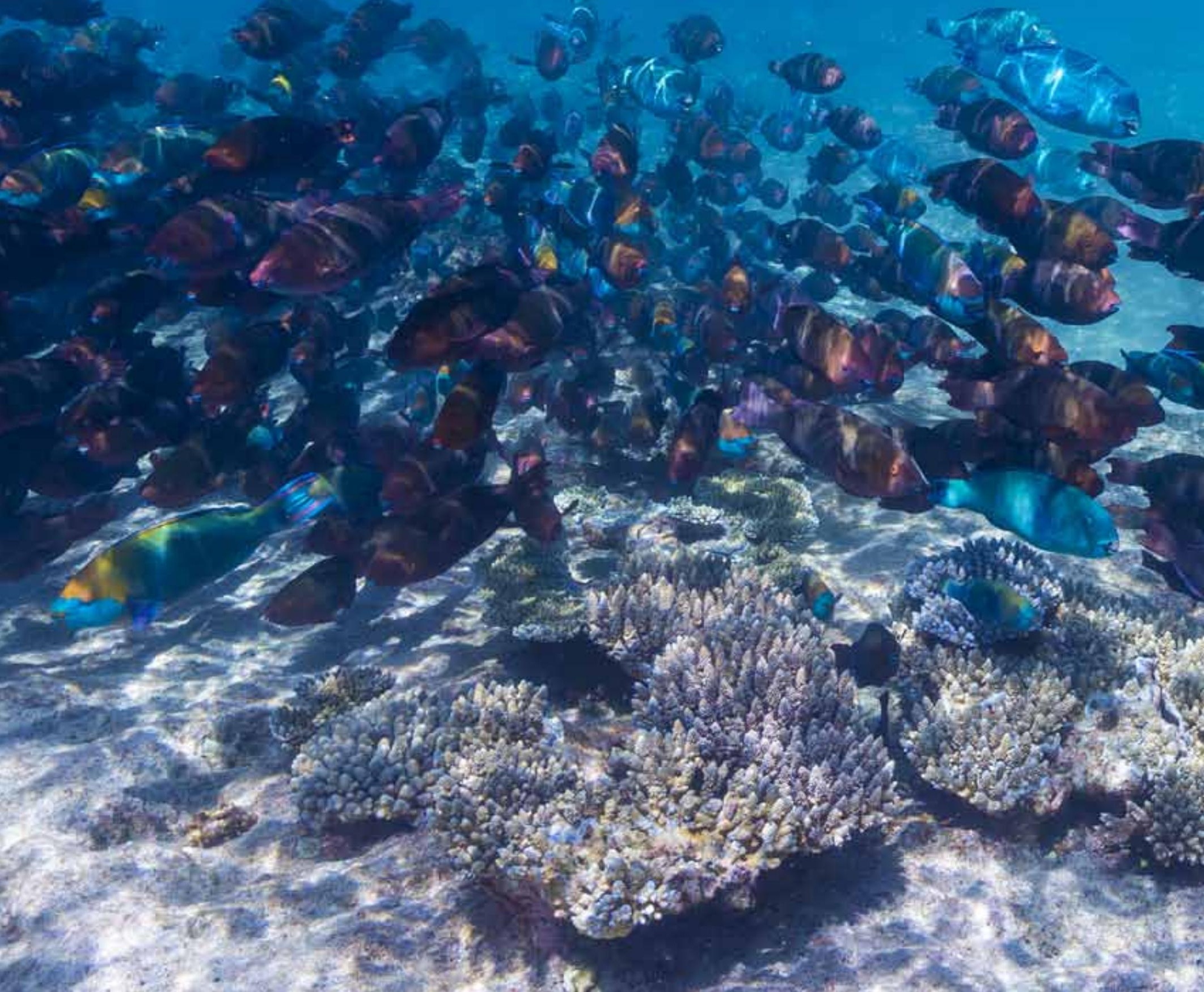




\section{BUDGET DEFICITS}

The government's fiscal position continues to deteriorate despite increased revenue collected through the taxes administered by Maldives Inland Revenue Authority (MIRA).

The primary cause of the government's ongoing budget deficits rests with spiraling expenditure, which the Minister of Finance and Treasury in 2013 described as "overwhelming." Increased pressure is placed on revenue raising to (at least partially) fund the expenditure.

During the tense political situation throughout 2012 and 2013, tax reforms made no progress in addressing the growing fiscal deficit problem. The Corporate Profit Tax (CPT) and Personal Income Tax (PIT) bills were held in abeyance at the parliamentary level. A new administration came into power in 2014 and introduced a new tax bill to Parliament.

\section{NEW TAXES}

The Sixth Amendment to the Maldives Tourism Act, ratified by the President on 17 December 2014, authorized the imposition of a "green tax" from 1 November 2015. The green tax is levied at a rate of $\$ 6$ per day on tourists for each day of their stay at a tourist resort, at a tourist hotel, or on a tourist vessel operated in Maldives (and, from 1 October 2016, \$3 per day on tourists who stay in guesthouses). ${ }^{1}$ This tax is, in effect, a reincarnation of the former tourism tax (except that it is imposed at lower rates). Given that Maldives faces the long-term threats of global warming and rising sea levels, the revenue collected by way of the green tax is intended (albeit not exclusively) for environmental protection measures.

Existing taxes alone are not enough to meet the government's additional revenue needs. To broaden the tax base, serious consideration should be given to the feasibility of introducing the following new taxes:

- personal income tax

- tonnage tax
- financial transactions tax

- wealth tax

- estate and/or inheritance tax

- emigration tax

- saturated fat and sugar tax

- municipal taxes

With respect to current tax rates, the government needs to consider

- increasing the corporate tax rate, which would not adversely affect Maldives' relatively competitive international tax rate ranking;

- adopting the International Monetary Fund's recommendation to increase the Toursim Goods and Services Tax (T-GST) rate to $15 \%$; and

- increasing the Withholding Tax (WHT) rate above $10 \%$, and introducing multiple WHT rates, depending on the nature of the payment to the offshore recipient.

Sections 1 and 4 of the Sixth Amendment to the Tourism Act (Law Number 42/2014). 
66 We need an income tax system. The $10 \%$ cap on related party remuneration deductions for $B P T$ is hard to monitor. The existing BPT system leads to a lot of tax avoidance. Income tax would not give a huge increase in revenue but it would complete the tax system. 99

Hassan Zareer

Deputy Commissioner General of Taxation 


\section{IMPACT OF THE TOURISM SECTOR}

The government's fiscal reforms have occurred against a background of fundamental change in the country's tourism market, on which the economy strongly depends. As already mentioned, since $60 \%$ of government revenue comes from tourism-related activities, ${ }^{2}$ the government's tax collection is particularly sensitive to behavioral changes in that sector.

Since the global financial crisis, the proportion of tourists from traditional European markets - primarily Germany, Italy, and the United Kingdom-has decreased (to $43 \%$ in 2015 from $79 \%$ in 2001). More recently, as a result of the economic downturn in the
Russian Federation, tourist arrivals from that country have fallen dramatically. Conversely, the proportion of visitors from the People's Republic of China has been increasing rapidly (to $29 \%$ in 2015 , from $7 \%$ in 2001), such that they now make up the largest country tourist group currently visiting Maldives. ${ }^{3}$

These contrasting statistics are reflected in the variable rates of growth in tourist arrivals from 1998 to 2015, as Figure 33 shows. The sharp downturn in 2005 is a consequence of the 2004 tsunami-the large reversal in 2006 reflecting the rapid recovery of the sector-while the declines in 2008 and 2009 mirror the effect of the global financial crisis.

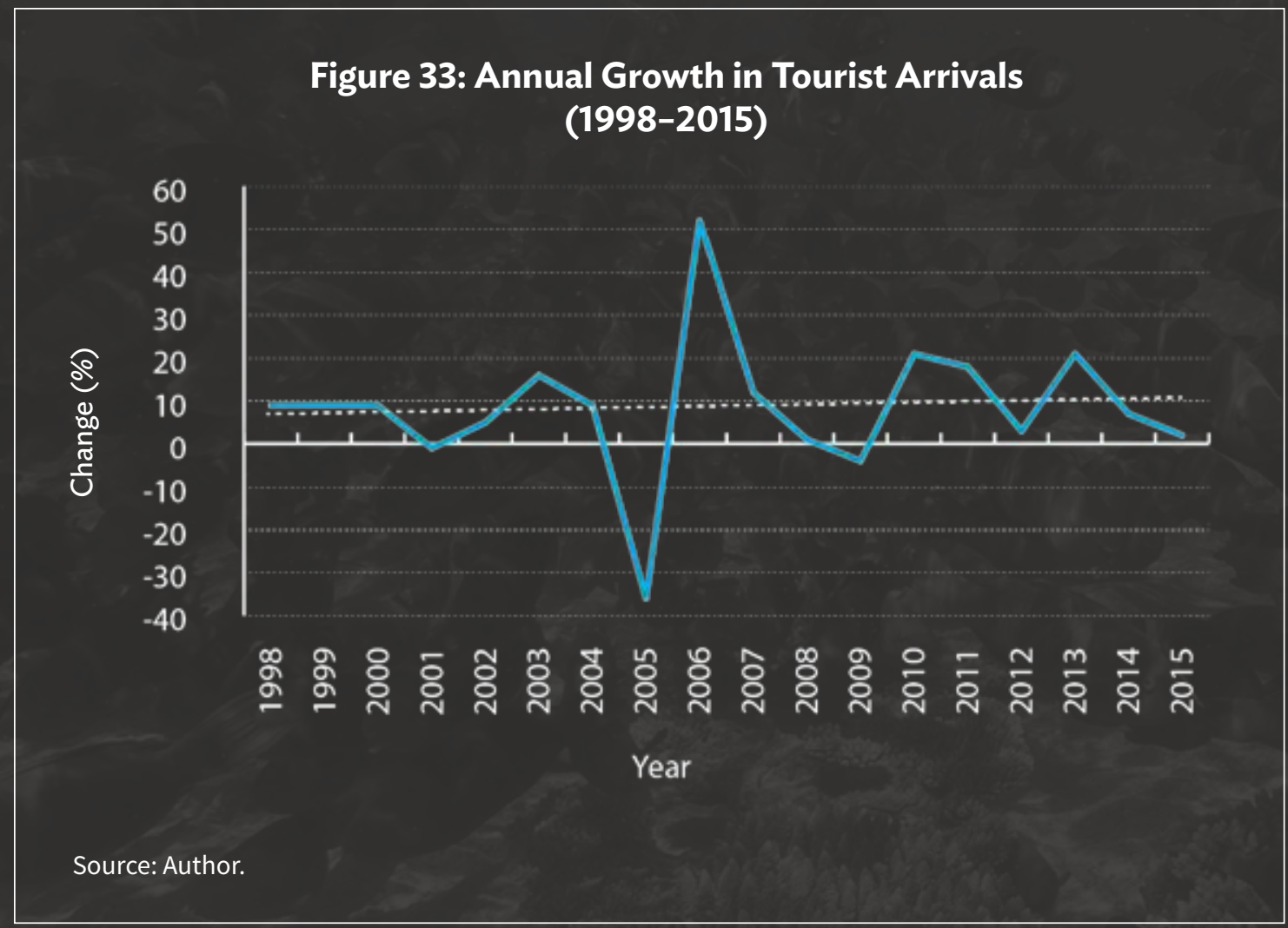


Although tourist numbers have steadily increased in recent years (in 2013, Maldives exceeded 1 million tourists for the first time), anecdotal evidence suggests that spending levels of tourists from the People's Republic of China (in terms of both accommodation and on non-accommodation items, such as food, drinks, leisure activities, retail shopping, etc.) are not as high as those of European tourists.

A second fundamental change in the tourism sector is a long-term downward trend in the length of a tourist's stay in Maldives. Figure 34 shows that the average length of a tourist's stay in Maldives has steadily declined from a peak of 9.0 nights in 1997 to 5.7 nights in 2015.

Both of these fundamental changes in the tourism sector have major ramifications for government revenue. In particular, tourist spending on both accommodation and extras drives Goods and Services Tax (GST) receipts. When those spending levels fall, the government's GST collections fall. When a decline in tourist spending levels squeezes the profitability of resorts, the government's Business Profit Tax (BPT) collections also fall. These changes in tourist patterns serve as a warning to the government to prioritize an examination of alternative sources of tax and nontax revenue, which is not dependent upon the vagaries of the tourism sector.

A further consideration in relation to the tourism sector is the ongoing need to ensure that both the GST and BPT tax nets adequately capture all revenue and profits derived by resorts and travel agencies and distributors, particularly those operated by multinational enterprises, which have the opportunity to retain foreign-sourced revenue offshore. A sharp focus on risk-based tax audits is necessary to maintain the tax base in this respect.

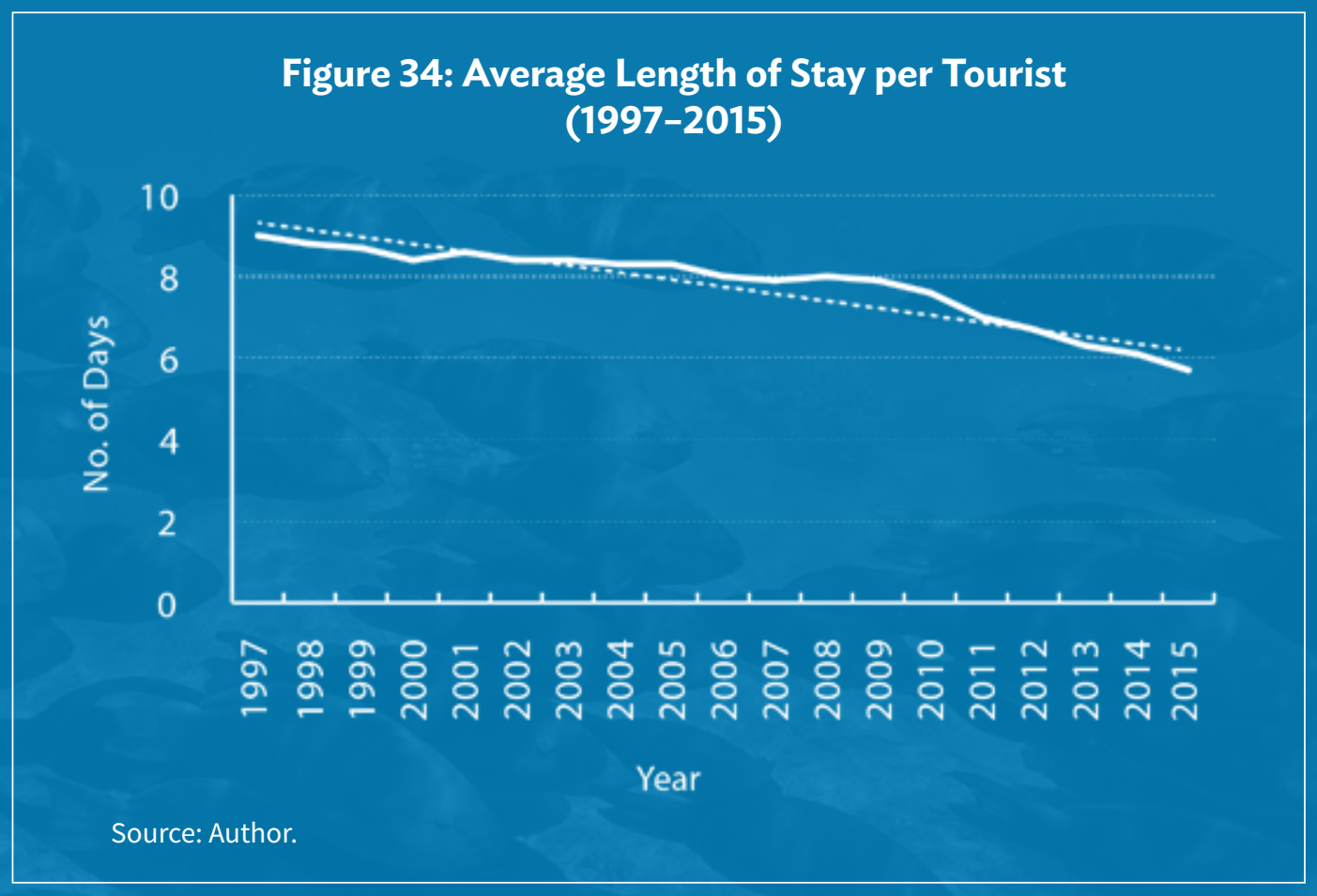

\section{FUTURE STRATEGY OF MALDIVES INLAND REVENUE AUTHORITY}

While MIRA has made enormous progress in implementing direct and indirect tax legislation in a very short period, it now faces the challenge of maintaining the impetus and building on its success. To do so, in 2014 MIRA developed its first 5-year strategic plan for 2015-2019. MIRA hopes to achieve the key performance indicators of the plan by the end of 2019.

Table 9 summarizes MIRA's strategic priorities and the corresponding key performance indicators. 
Strategic Priority

$3 \quad$ Protect the revenue base by promoting voluntary compliance and deterring abuse of the tax system

$4 \quad$ Improve the ability to provide assistance to taxpayers and to manage debt collection

$5 \quad$ Implement sustainable cost saving strategies and strengthen governance

$6 \quad$ Implement resource management strategies aimed at increasing productivity

$7 \quad$ Provide business solutions and state-of-the-art technology to strengthen both corporate affairs and tax administration

\section{Key Performance Indicators}

- Achieve at least a $95 \%$ on-time filing and payment rate

- Annual increment in the percentage of returns filed without errors

- Establish a fully automated risk profiling and audit selection system

- Annual reduction in the arrears-to-collection ratio

- Annual reduction in the number of days taken to collect arrears from a taxpayer

- Improve the spending-to-collection ratio to 0.4 laari per $\mathrm{Rf} 1$ collected

- Communicate organisational risks to staff and take steps to minimise the risks

- Publication of information at regular intervals

- At least $80 \%$ of staff achieving $75 \%$ or higher in quarterly performance appraisals

- Improve the graduate:total employees ratio to $70 \%$

- At least $20 \%$ of staff are members of a professional accounting body

- Retain at least $90 \%$ of staff annually

- Increase the working area per staff member

- Automate all administrative processes

- Improve service standards to fulfill the requirements of ISO9001

- Integrate all revenue collection into a single platform

- Zero data errors

MIRA = Maldives Inland Revenue Authority.

Source: MIRA. 
66 MIRA is an extremely powerful organization in Maldives. MIRA must not become authoritarian or the public's trust in it will be undermined. MIRA has done a very good job meeting the challenges of implementing BPT and GST. We have had meaningful discussions with MIRA and resolved tax issues for our clients amicably. MIRA now needs to work hard to maintain that. 99

Krishna Rengaraj Tax Partner, EY Maldives

66 To maintain the impetus of the MIRA's success, we need a better targeted auditing approach based on risk assessments and stricter requirements for businesses to keep in Maldives more documentation of their transactions. 99

Fathuhulla Jameel Director General - Audit and Investigation, MIRA (2012-2016)

66 The tax reforms are something we always needed, rather than just customs duties. But I want to know how the tax money is used, especially when we are paying a lot of tax. There are so many things that have to be done. Just look around Male'. 99

Anonymous businessman 
CHAPTER 8

Learning from the Maldives Experience 
All countries with fledgling tax systems (including Maldives itself) have much to learn from the tax reforms instituted in Maldives during the period from 2010 to 2015.
Lessons to achieve best practices can be learned at the tax policy, legislation and administrative levels.

\section{TAX POLICY}

- Address tax revenue reform requirements at a political level on a timely and expeditious basis.

- Take decisive action to introduce tax reforms once the need for them is recognized.

- Don't defer implementation of tax reforms needed to address increasing fiscal deficits-that simply results in more pain later.

- Ensure that the government properly settles its $\operatorname{tax}$ policy position before it enacts its tax legislation.

- Stagger the introduction of new tax laws.

- Ensure that proper transitional mechanisms are in place at the date of commencement of a new tax law.

- Develop a close liaison between the government and the tax administration on tax policy matters, decisions about which are ultimately the prerogative of the government. This could be achieved by formal use of Ministry of Finance representatives on the Board of the tax authority.
- Embrace a broad business income tax base, by adopting:

» a broadly scoped and well defined WHT regime,

» a comprehensive general anti-avoidance rule,

» controlled foreign company rules,

» thin capitalization rules, and

» robust transfer pricing rules or a unitary apportionment method of allocating an appropriate share of a multinational enterprise's profits to the developing country.

- Adopt a realistic establishment period for the introduction of new taxes.

- Coordinate with the Central Bank in advance of the introduction of indirect taxes to ensure that there are sufficient notes and coins of the right denomination in circulation to meet the requirement for businesses to give the correct change in transactions with their customers.

- Implement a self-assessment regime with realistic deterrent penalties for offenses. 


\section{TAX LEGISLATION}

- Draft coherent tax law, which is consistent with the country's Constitution and other laws, especially other tax laws.

- Write simple, clear, and unambiguous legislation.

- Ensure English translations of laws and regulations are accurate.

- Release proposed laws, regulations, and rulings for public consultation before finalization.

- Adopt a "generic tax policy process," which allows for amendments to parliamentary law at least annually, to enact new tax policies, to correct deficiencies in extant tax legislation and to keep abreast of changes in the commercial environment.

- Recognize democratic parliamentary authority and the rule of law, such that subordinate regulations and rulings are not used as a substitute for primary law, to impose substantive taxing provisions (or to relieve them). This requires

\section{TAX ADMINISTRATION}

- Establish an independent revenue authority, governed by its own statute.

- Properly plan the implementation of the tax administration system.

- Formulate a comprehensive organizational structure with clear lines of authority and responsibilities.

- Formalize information flows between the government policymakers and the tax authority, and vice versa.

- Develop internal operational and administrative procedures.

- Recruit young qualified staff, committed to the organization's objectives, and untainted by undesirable past work practices.

- Subject all staff to periodic anticorruption reviews.
Parliament to fulfil its role in competently scrutinizing proposed legislation put before it and to enact tax laws in the interests of the general population. This objective would be facilitated by adoption of a generic tax policy process, referred on p. 138.

- Take cognizance of:

» tax avoidance opportunities presented by poorly written tax legislation, which results in undermining the tax base, and

» taxpayer compliance and tax administration costs imposed by unnecessarily complex or burdensome legislation and tax rulings.

- Closely review parliamentary legislation to identify areas that need to be supplemented by regulations, and write those regulations.

- Require legal draftsmen to liaise with tax administrators to write tax law capable of practical application.
- To maintain public trust in the tax system, instill in staff the importance of keeping taxpayer information confidential.

- Reward staff for good performance.

- Undertake a training needs analysis and invest heavily in staff training at technical, career development, and personal levels.

- Develop training materials, and plan and deliver training (and evaluate the effectiveness of the training).

- Ensure that the judiciary is adequately trained in tax law.

- Obtain financial assistance from international development organizations to fund the appointment of appropriately qualified and experienced external tax consultants to work 
alongside, and to build professional relationships with, staff by providing on-the-job assistance and training on a flexible long-term basis.

- Design and devote substantial time and resources to a comprehensive taxpayer awareness campaign.

- Ensure that an extensive taxpayer registration database is compiled, using corroborating data from other government registration agencies and intelligence from the tax authority's existing information databases.

- Invest in taxpayer service centers, to assist taxpayers to meet their obligations and to understand their rights under the new tax laws.

- Publish a Taxpayers' Charter which sets out taxpayers' rights and obligations and the tax administration's service standards.

- Ensure that taxpayers have, or are educated to adopt, proper recordkeeping systems to support voluntary tax compliance.

- Widely disseminate tax information among the (taxpayer and nontaxpayer) population, especially making full use of social media and modern communication technology.

- Regularly publish tax rulings and guides to assist taxpayers to interpret the laws and to understand how the tax administration interprets them.

- Institute a properly resourced compliance monitoring regime, including compliance visits to taxpayers.

- Carry out audits on samples of taxpayers, which are selected using risk profiling techniques.

- Engage external expertise if auditors are inexperienced.

- Place a sharp focus on material audit risk and devote audit resources to areas where the greatest potential tax revenue gains are likely to prevail, viz. large taxpayers, by adopting business intelligence software to analyze data in the taxpayer IT database.

- Identify large taxpayers which are critical to revenue collection performance, and establish a dedicated unit to deal with all tax matters relating to them directly.

- Ensure robust enforcement policies are developed, published, and carried out.

- To enhance the level of taxpayer compliance and to utilize the tax administration's resources effectively, introduce a licensed tax agent regime, allowing the tax agents to act as intermediaries between taxpayers and the tax administration.

- Provide the public with monthly, quarterly, and annual performance reports.

- Ensure that the privacy provisions of the taxing statutes permit exchange of information between the tax authority and other domestic government bodies and foreign tax authorities.

- Quickly progress double tax agreement and tax information exchange agreement negotiations with trading and investor partner countries.

- Become affiliated with international tax bodies, to facilitate exchange of knowledge and information, and to take advantage of training opportunities.

- Implement a modern online based IT system, which facilitates automation of internal processes and interactions with taxpayers, such as online return filing and an online tax payment system.

- Formulate a strategic plan, which sets out the tax administration's objectives, path forward, and key performance indicators for the medium- to longterm. 


\section{The tax system is working as anticipated. There have been hiccups, but the system has been fine tuned in response to them.}

\section{I have high hopes for the Maldives tax system! 99}

Fathuhulla Jameel

Director General-Audit and Investigation, MIRA (2012-2016) 
On pace of change

66 The tax reforms were the right step to achieve the government's policy objective of reforming the economy, but we should not make too many changes at once, or the government becomes open to challenge from vested interest groups on too many fronts. We also need to make sure that businesses have adequate bookkeeping systems and access to accounting skills to implement tax reforms. 99

Ali Hashim Minister of Finance and Treasury (2008-2010)

On Tourism Goods and Services Tax

66 T-GST was introduced as a first step for general GST to be introduced later. T-GST was introduced first because the tourism sector had systems in place to implement it. 99

Arshad Jameel

Managing Partner, Urban Stitch Partnership, Male', and Consultant to President's Office (2008-2011)

On Goods and Services Tax and Small and Medium-Sized Entrepreneurs

66 When the government introduced GST, we recognized that SMEs did not have proper recording systems. That took away some of the effectiveness of GST. SMEs need help with IT systems to record transactions and to get them registered. 99 
On tax administration

66 We must increase efficiency in administration of tax laws by stronger enforcement, and make compliance easier for small taxpayers with more taxpayer education and increased automation. 99

Abdulla Jihad

Vice-President Minister of Finance and Treasury (2008, 2012-2016)

On income tax

66 Maldives needs to introduce an income tax alongside BPT. The tax system cannot work properly until it includes income tax. There are high-income foreign employees in the resorts who should be paying tax here. 99

President Mohamed Nasheed

President of Maldives 2008-2012 
On record-keeping

66 The biggest challenge of initially implementing BPT and GST was the lack of documentation and books kept by Maldives businesses. We educated taxpayers not only about the taxes but the need to keep books. This was made more difficult because Maldives is spread over 200 inhabited islands. We visited all those islands and provided bookkeeping templates to help taxpayers get started. 99

Fathuhulla Jameel Director General-Audit and Investigation, MIRA (2012-2016)

On taxpayer education

66 The tax system is new. There are not enough trained people. Only now are we catering for MIRA's needs. The MIRA Tax Academy is the first step in achieving our long-term training goal. We don't have trained people in Maldives who are highly tax literate. The Tax Academy will offer courses which can be recognized by everyone. They will be incorporated into the National Qualifications framework. I want tax concepts included in the Ministry of Education syllabus and "tax" to be a GCE O-level [GCSE] subject, and MNU [Maldives National University] to include tax modules like F6-ACCA in its business programmes, as they do already for tourism studies, which is also taught in schools. Children have more interest in tax generally now. 99

Yazeed Mohamed 
On payment of tax

66 The banking system was also a big challenge. Only the Bank of Maldives reaches the atolls, and there it has only limited facilities. 99

Hassan Zareer

Deputy Commissioner General of Taxation

On income tax

66 Tax could be extended to wages. We already have pension administration. It would be administratively easy to tax wages. 99

Fathuhulla Jameel Director General-Audit and Investigation, MIRA (2012-2016)

On Maldives Inland Revenue Authority's reputation and performance

66 MIRA has established a reputable position by overcoming the obstacles encountered during the initial stages. We started from zero with new recruits in a new area. But we are not close to success yet. We have achieved a bare minimum to sustain the organization. We have been subjected to budgetary and human resource constraints. 99

Yazeed Mohamed

Commissioner General of Taxation 
On Maldives Inland Revenue Authority audits

66 It took more than a year to finish our audit, and MIRA did not communicate with us before giving their final report and sending a NOTA [Notice of tax assessment]. 99

Anwarusalam Aboobakuru Chief Operating Officer, Biyalanco, Kulhudhuffushi

On customs duty

66 But customs taxes are continuing. Why are they still continuing? We are being taxed twice. 99

Anonymous businessman

On income tax

$\mathbf{6} 6$ I think that we should have an income tax system as well to apply to everyone-not just businesses-because so many people are outside the system, and we should bring them in. 99 


\section{On the Reform Program}

$\boldsymbol{G} 6$ In over 20 years working on public sector management reforms across Asia and the Pacific countries, I have yet to see a country other than Maldives, to overhaul and adapt a modern tax system so successfully in such a short space of time. Truly amazing and very proud that $A D B$ was able to contribute to this success story.

The success of the adoption of a modern tax system in Maldives will be reflected more in the extension $\&$ improvement of service delivery now being financed, rather than in the tax yields, and that will improve the life of every Maldivian. 99

Bruno Carrasco Director, Public Management, Financial Sector and Trade Division, South Asia Department

On Maldives Inland Revenue Authority staff:

66 The success of the project is simple: team work. ADB provides finance and international expertise and the team at MIRA brings dedication, professionalism, and vision. 99

Natalie Bertsch Maldives Team Leader

66 It is gratifying to work with the dynamic and proactive MIRA staff and to bear witness to the fruits of their labor. 99 
On Maldives Inland Revenue Authority

66 The speed of change and the pace of implementation of tax reform in Maldives are impressive. MIRA have recruited and developed a pool of very capable and dedicated staff who are passionate about their individual roles and the collective responsibilities of MIRA. Taxpayer education on their rights and obligations has been critical and MIRA has devoted considerable time and resources to public education. 99

On Maldives Inland Revenue Authority staff

66 When they arrive at MIRA, the staff have no previous experience of tax administration. However, they are a young, enthusiastic, and competent cohort, who are keen to learn and are committed to implementing the fiscal reforms under their jurisdiction. They work long hours, including weekends, to achieve that objective. Only with the staff's continued dedication will the successful implementation of the government's bold tax reform programme be maintained. The danger, of course, is that if the benefits of the past and ongoing reforms are not evident, staff will become demoralized, and will seek alternative employment. $९ 9$ 
66 The obligation on a taxpayer to pay the full tax in dispute to have a valid challenge is harsh and may prevent taxpayers with limited resources from pursuing legitimate challenges. Consideration could be given to allowing MIRA to waive or relax this requirement, or to accept securities for these purposes. 99

Colin Hutchins ADB International Audit Consultant to MIRA (2012-2013)

On taxpayer education and transparency

66 Maldivians have to understand that, in the words of Milton Friedman, 'there is no such thing as a free lunch,' and that, one way or another, they have to pay for the public goods, which they demand from the government. For Maldivians to accept tax reforms, the government needs to be more transparent about where the tax it collects actually ends up. 99

Kevin Holmes ADB International Tax Advisor to Maldives (2011-2015)

66 MIRA needs to continue to educate the local population, not only on their obligations, but also on the social purpose of taxation and the transparency of government spending. Taxpayers will be more likely to comply with their obligations if they understand and believe that their contribution to the tax take is used for proper purposes and to improve the lot of all Maldivians. 99

Colin Hutchins ADB International Audit Consultant to MIRA (2012-2013) 
On personal income tax

66 The delays in the introduction of a personal income tax have meant that structural distortions remain. Limits have been placed on the deductions available for business owner remuneration which are arbitrary and mean that remuneration decisions may be based on tax rather than commercial imperatives. 99 


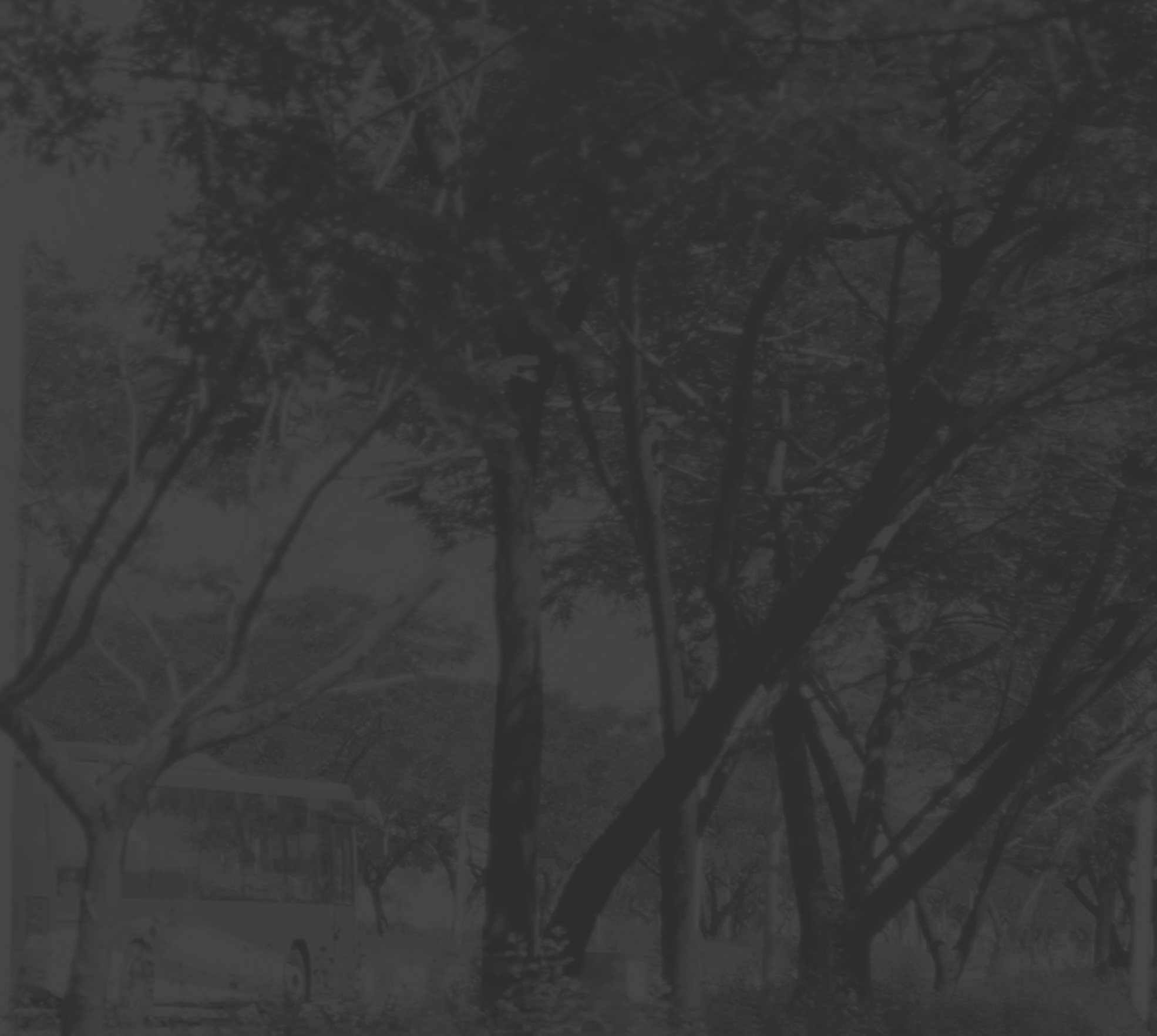




\section{Fast-Track Tax Reform Lessons from Maldives}

The economy of Maldives faced two very challenging episodes traced to the 2004 tsunami and the 20082009 global financial crisis. To develop alternative sources of funding and to improve services delivery, the government, with the help of partners like the Asian Development Bank and others, succeeded in transforming the country's revenue system into a modern, e-enabled system for effective tax collection and development of a broader tax base. Find out more about Maldives' fast-track approach to tax reforms which can serve as a guide for other developing countries.

\section{About the Asian Development Bank}

ADB's vision is an Asia and Pacific region free of poverty. Its mission is to help its developing member countries reduce poverty and improve the quality of life of their people. Despite the region's many successes, it remains home to a large share of the world's poor. ADB is committed to reducing poverty through inclusive economic growth, environmentally sustainable growth, and regional integration.

Based in Manila, ADB is owned by 67 members, including 48 from the region. Its main instruments for helping its developing member countries are policy dialogue, loans, equity investments, guarantees, grants, and technical assistance. 